\begin{abstract}
TnC
CENTRO UNIVERSITÁRIO DE BRASÍLIA - UnICEUB

FACULDADE DE TECNOLOGIA E CIÊNCIAS SOCIAIS APLICADAS - FATECS

PROGRAMA DE INICIAÇÃO CIENTÍFICA

JOÃO PEDRO FERREIRA LISBOA DE ALMEIDA

ROMÁRIO DOUGLLAS NOVAES DOS SANTOS
\end{abstract}

ESTUDO DE PARÂMETROS EM LABORATÓRIO DE MISTURA DE SOLOLIGNOSULFONATO PARA ESTABILIDADE DE TALUDES PARA BARRAGENS DE PEQUENO PORTE

BRASÍLIA

2017

JOÃO PEDRO FERREIRA LISBOA DE ALMEIDA 


\section{$1 \quad$ \\ Unceus \\ ROMÁRIO DOUGLLAS NOVAES DOS SANTOS}

Estudo de Parâmetros em Laboratório de Mistura de Solo-Lignosulfonato para Estabilidade de Taludes para Barragens de Pequeno Porte

Relatório final de pesquisa de Iniciação Científica apresentado à Assessoria de PósGraduação e Pesquisa pela Faculdade de Tecnologia e Ciências Sociais Aplicadas FATECS

Orientação: Jairo Furtado Nogueira, M.Sc.

\section{Brasília}




\title{
ESTUDO DE PARÂMETROS EM LABORATÓRIO DE MISTURA SOLO- LIGNOSULFONATO PARA ESTABILIDADE DE TALUDE PARA BARRAGENS DE PEQUENO PORTE
}

\author{
João Pedro Ferreira Lisboa de Almeida - UniCEUB, PIC Institucional, aluno bolsista \\ contato.joaopedro@hotmail.com
}
Romário Dougllas Novaes dos Santos - UniCEUB, PIC institucional, aluno voluntário romario.office@gmail.com

\author{
Jairo Furtado Nogueira - UniCEUB, professor orientador \\ jairo.nogueira@uniceub.br
}

Nesta pesquisa, tem como objetivo apresentar os fatores de segurança para aterros compactados com solo residual típico do Distrito Federal classificado como pedregulho areno-siltoso, com adição de $2 \%$ e $4 \%$ de lignosulfonato como solução de solo melhorado com lignina e $6 \%$ e $8 \%$ como mistura solo-lignosulfonato e sem adição (solo natural) conforme o Manual de pavimentação do Departamento Nacional de Infra-Estrutura de Transportes - DNIT, na qual verificou-se após realizações de ensaios de resistência de cisalhamento direto o percentual de $8 \%$ apresentou melhores resultados se comparado com as outras adições e ao solo natural sem mistura. Conforme estudos realizados por Rezende at all. (2015) para a simulação das condições de baixo controle de compactação, foram estudados os todos os teores de umidade e da ótima no processo de compactação do solo e para todas as adições de lignosulfonato já citadas. Os resultados obtidos demonstraram que a variação da estabilidade dos aterros estudados, de acordo com a umidade, densidade de compactação, parâmetros de resistência (coesão e ângulo de atrito) e das inclinações de taludes sugeridas pela literatura foram verificados pelos valores dos fatores de segurança, onde os maiores fatores encontrados foram para os melhores resultados ensaiados.

Palavras-Chave: Rejeito, barragens, estabilidade, ensaios, lignina. 


\section{SUMÁRIO}

1 INTRODUÇÃO

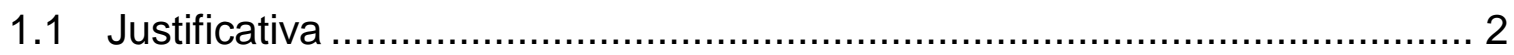

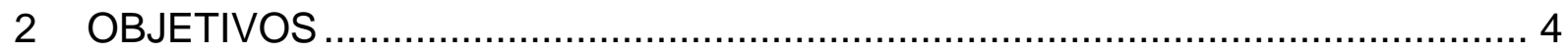

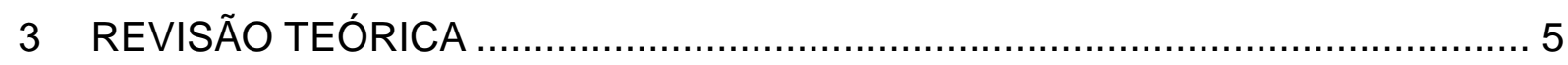

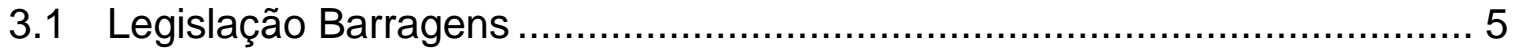

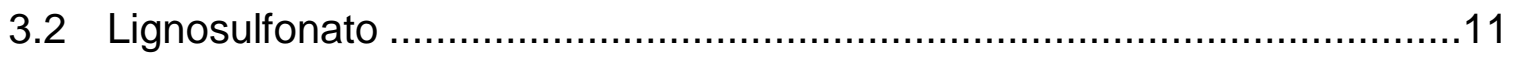

3.3 Barragens de rejeitos e mineração ......................................................13

3.4 Modelos construtivos de barragens de rejeitos.......................................15

3.5 Estabilidade de talude em barragens de terra .........................................17

4 MATERIAIS E METODOLOGIA DE TRABALHO ..........................................19

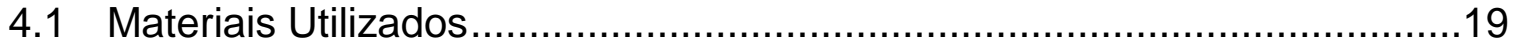

4.1.1 Localização da retirada de amostra do solo ...................................19

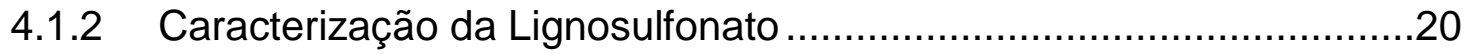

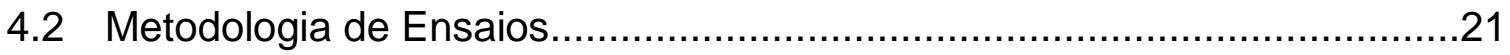

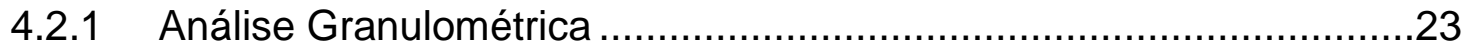

4.2.2 Massa Específica Real dos Grãos ............................................27

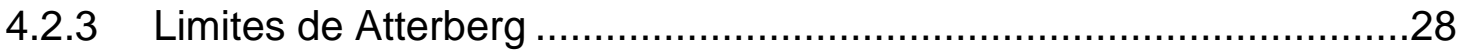

4.2.4 Identificação e Descrição Expedita de solos, metodologia MCT ........30

4.2.5 Massa específica da Lignosulfonato ….......................................32

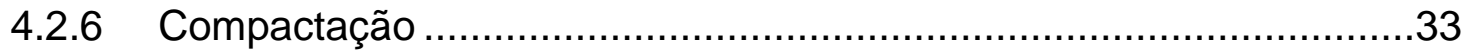

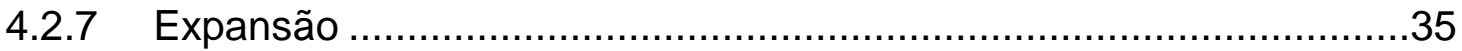

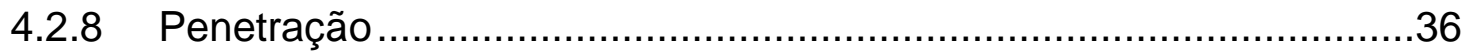

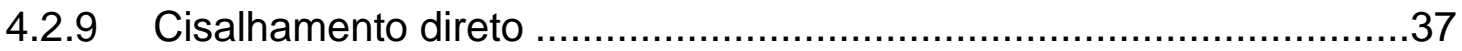

4.2.10 Simulação numérica da barragem..........Erro! Indicador não definido.

5 APRESENTAÇÃO E ANÁLISE DOS RESULTADOS …................................40

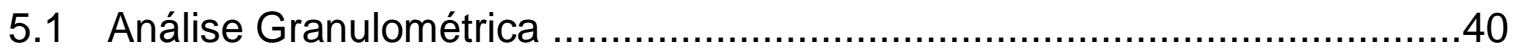

5.2 Massa Específica Real dos Grãos ....................................................

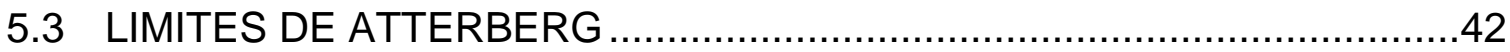

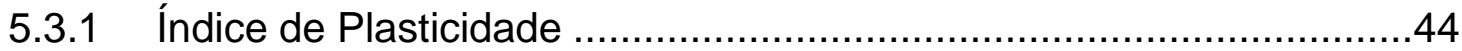

5.4 Identificação e Descrição Expedita de solos, metodologia MCT …….........45

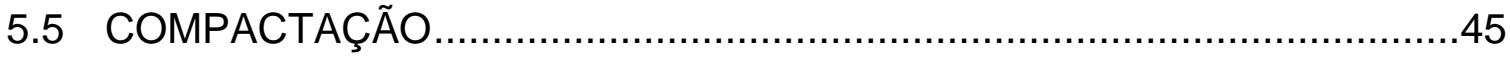

5.6 EXPANSÃO …………………....................... Erro! Indicador não definido.

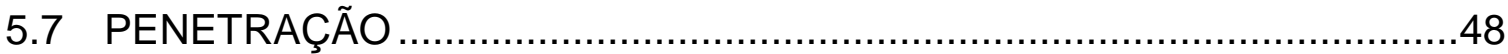

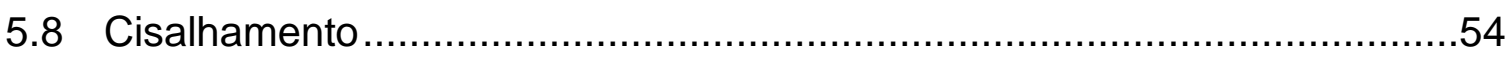


6 CONCLUSÃO

7 REFERÊNCIAS 


\section{LISTA DE FIGURAS}

Figura 1 - Potencial de Mercado - Lignina (2011) ............................................ 11

Figura 2 - Estrutura da parede celular vegetal.................................................. 12

Figura 3 - Alteamento pelo método de montante................................................ 15

Figura 4 - Alteamento pelo método de jusante. .................................................. 16

Figura 5 - Alteamento pelo método de linha de centro. ........................................ 16

Figura 6 - Localização do local de retirada da amostra deformada de solo............. 19

Figura 7 - Retirada de amostra deformada de solo para aterro ............................ 20

Figura 8 - Localização da indústria da produção de papel e do rejeito utilizado...... 21

Figura 9 - Amostra do solo secando ao ar livre ................................................ 22

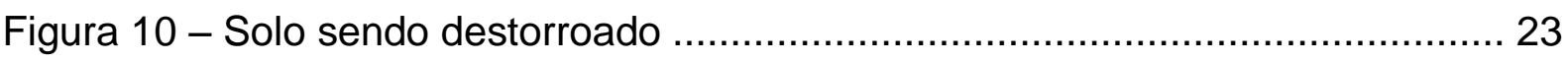

Figura 11 - Peneiras para granulometria grossa.................................................. 25

Figura 12 - Equipamentos utilizados no ensaio de sedimentação ........................... 26

Figura 13 - Peneiras no agitador mecânico …………...................................... 27

Figura 14 - Amostras na bomba de vácuo ...................................................... 28

Figura 15 - Aparelho de Casagrande........................................................... 29

Figura 16 - Cilindro de solo ensaiado para o Limite de Plasticidade ...................... 29

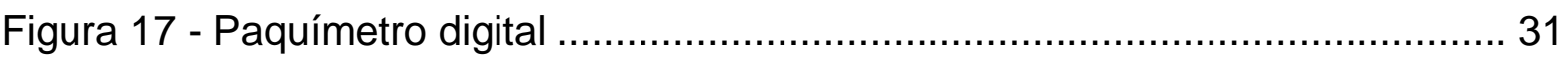

Figura 18 - Pastilhas submetidas à reabsorção d'água ............................................ 31

Figura 19 - Determinação da penetração nas pastilhas de solo depois de

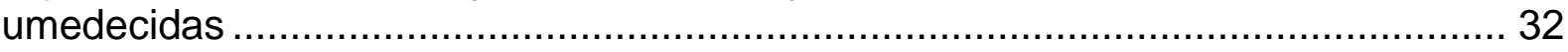

Figura 20 - Medição do peso do molde de cilindro mais Lignosulfonato ................. 33

Figura 21 - Corpo de prova desmoldado com adição de 2\% de Lignosulfonato...... 35

Figura 22 - Corpos de prova imersos em água................................................. 36

Figura 23 - Ensaio de penetração em andamento ………………….................. 37

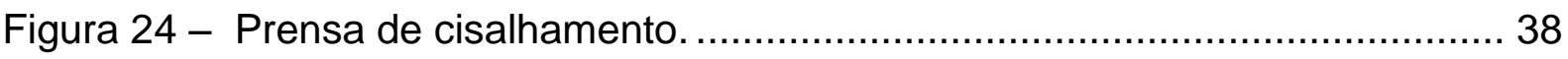

Figura 25 - llustração da barragem usada no trabalho Erro! Indicador não definido.

Figura 26 - Curvas granulométricas do solo com e sem defloculante .................... 41

Figura 27 - Curva do Limite de Liquidez ....................................................... 43

Figura 28 - Comparativo entre a compactação do solo natural e do solo com suas

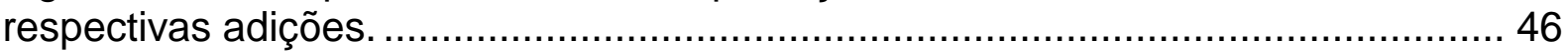

Figura 29 - Peso específico máximo seco x umidade ótima parar todas as curvas de

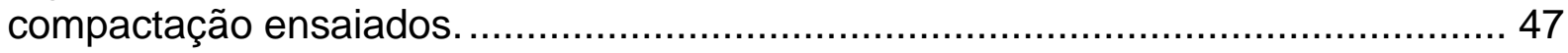

Figura 30 - Apresenta os resultados para penetração x pressão do solo natural. ... 48 Figura 31 - Ensaio de penetração $x$ pressão do solo com adição de $2 \%$ lignosulfonato. 
Figura 32 - Ensaio de penetração versus penetração do solo com adição de 4\% lignosulfonato. ......................................................................................... 50

Figura 33 - Ensaio de penetração versus pressão do solo com adição de $6 \%$

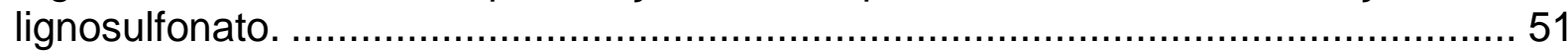

Figura 34 - Ensaio de penetração versus pressão do solo com adição de $8 \%$

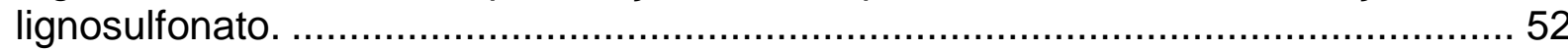

Figura 35 - Comparativo entre os melhores resultados de I.S.C dentre todas as amostras dos ensaios de compactação das misturas e solo natural........................ 53

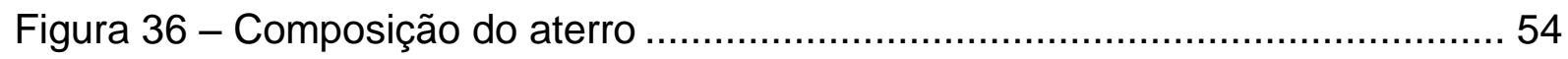

Figura 37 - Influência das umidades na coesão das amostras ensaiadas............... 55

Figura 38 - Influência do ângulo de atrito na coesão ......................................... 56 


\section{LISTA DE TABELAS}

Tabela 1 - Maiores acidentes com mortes em barragens de rejeitos e com contaminação (Avila, 2016).

Tabela 2 - Matriz para classificação de barragens para disposição de resíduos e rejeitos (DNPM, 2015).

Tabela 3 - Característica técnica CT - (DNPM, 2015)........................................ 7

Tabela 4 - Estado de conservação - EC (DNPM, 2015) ……............................. 7

Tabela 5 - Plano de segurança de barragens - OS (DNPM, 2015) ......................... 8

Tabela 6 - Quadro de classificação quanto ao dano potencial associado - DPA (Resíduo e Rejeitos) 10

Tabela 7 - Composição média de madeira de coníferas e folhosas. ....................... 13

Tabela 8 - Valores de massa específica......................................................... 21

Tabela 9 - Quantidade de amostra para análise granulométrica ........................... 24

Tabela 10 - Balança a ser utilizada na Análise Granulométrica.............................. 24

Tabela 11 - Material retido no peneiramento grosso ............................................ 40

Tabela 12 - Material retido no peneiramento fino ………................................... 40

Tabela 13 - Granulometria do solo ensaiado ................................................... 42

Tabela 14 - Resultado do ensaio de massa específica real dos grãos .................... 42

Tabela 15 - Resultados do Limite de Liquidez ................................................. 43

Tabela 16 - Resultado do Limite de Plasticidade ................................................ 44

Tabela 17 - Limites de Atterberg - Índice de Plasticidade ..................................... 44

Tabela 18 - Classificação de Burmister para o Índice de Plasticidade .................... 44

Tabela 19 - Limites de Atterberg.................................................................. 45

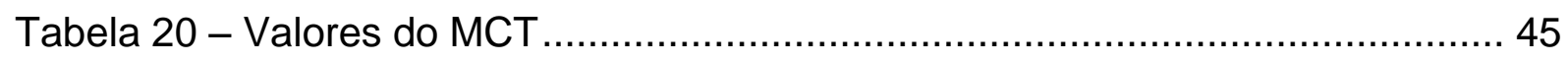

Tabela 21 - Relação da umidade ótima e peso especifico seco máximo para todas as amostras ensaiadas. 


\section{LISTA DE ABREVIAÇÕES}

AASHTO.............American Association of State Highway and Transportation Officials

ABNT Associação Brasileira de Normas Técnicas

ASTM American Society for Testing and Materials

CBR California Bearing Ratio

CNT. .Confederação Nacional do Transporte

DNIT Departamento Nacional de Infraestrutura de Transportes

DNER Departamento Nacional de Estradas de Rodagem IBGE Instituto Brasileiro de Geografia e Estatística

I.S.C Índice de Suporte Califórnia

DNER Departamento Nacional de Estradas de Rodagem EPS Expanded Polystyrene

NBR Norma Brasileira Regulamentadora SUCS Sistema Unificado de Classificação de Solos MCT Miniatura Compactado Tropical 


\section{LISTA DE SIMBOLOS}

$\mathrm{G}_{\mathrm{s}}$ Massa específica dos grãos

LL. ..Limite de Liquidez

LP Limite de Plasticidade

IP. .Índice de Plasticidade $\mathrm{w} \%$ ..Teor de umidade wótimo. Teor de umidade ótimo $\delta_{\mathrm{T}}$. Massa específica da água Yd. Peso específico seco 


\section{INTRODUÇÃO}

A atividade mineradora possui um importante papel na economia para 0 desenvolvimento e manutenção do modo de vida do ser humano moderno (Branquinho, 2014). Porém, essa atividade extrativista a nível mundial vem gerando números cada vez mais elevados de resíduos, provenientes do beneficiamento do minério. Esse processo gera produtos, muitas vezes, tóxicos, que podem colocar o meio ambiente e as comunidades vizinhas em risco com relação tanto à preservação da biodiversidade, quanto à poluição de fontes de água potável. Após etapas da mineração, estes rejeitos da extração de minério são, na maioria das vezes, depositados em estruturas denominadas diques ou barragens de rejeitos. As condições de construção, manutenção e monitoramento dessas estruturas são de suma importância para a sua segurança estrutural. Em geral, essas estruturas de barramento são construídas com materiais naturais, como solo ou enrocamento, presentes na região, misturados ou não com o próprio rejeito. Devido a comum heterogeneidade desses materiais, uma avaliação estatística pode ser uma ferramenta auxiliar para a determinação da variação dos parâmetros geotécnicos desses materiais e de seus efeitos na estabilidade das estruturas.

Inicialmente essa pesquisa seguiu com uma revisão bibliográfica abordando a legislação vigente no que diz respeito à construção, controle e manutenção de barragens de rejeito. Posteriormente, a pesquisa discorre sobre a teoria que engloba a estabilidade de talude e seus mecanismos de ruptura. Em seguida foi feito uma análise dividida em: metodologia do trabalho, obtenção de dados (parâmetros) em laboratório, cálculos e análise dos resultados. Através dos ensaios realizados em laboratório, os resultados encontrados foram verificados e analisados quanto a estabilidade de um aterro de barragem e consequentemente ao fator de segurança apresentando a melhor opção das condições propostas nessa pesquisa analisando as considerações dos padrões recomendados para construção de barragens. A proposta do estudo de misturas foi verificar a possibilidade de apresentar resultados favoráveis, recomendadas medidas e intervenções da engenharia para melhorar as condições atuais da barragem estudada. 


\subsection{JUSTIFICATIVA}

Para se perceber a importância tanto dos materiais de construção civil ou de qualquer outra indústria no contexto da sustentabilidade é importante saber quais os impactos ambientais provocados pela extração das matérias-primas necessárias a sua produção. Neste âmbito, uma questão ambiental mais pertinente, mais pouco consensual, a possibilidade de esgotamento das matérias-primas não renováveis. Mas o maior problema ambiental associado aos materiais das indústrias, não será a possibilidade de esgotamento dessas matérias-primas não renováveis, mas os impactos ambientais provocados pela sua extração, gerados durante as atividades de mineração.

Histórico de acidentes reportados pela International Commission on Large Dams ICOLD (2001) apud Ávila (2012) indica que as principais causas de ruptura de barragens são oriundas de problemas de fundação, capacidade inadequada dos vertedouros, instabilidade dos taludes, falta de controle da erosão, deficiências no controle e inspeção pós-fechamento e falta de dispositivos graduais de segurança ao longo da vida útil da estrutura. Exemplos de rupturas no Brasil de barragens de contenção de rejeitos e de resíduos industriais que custaram vidas, recursos naturais e materiais, e os acidentes sem mortes, mas com contaminação são abordados na Tabela 1 (Avila, 2016).

Tabela 1 - Maiores acidentes com mortes em barragens de rejeitos e com contaminação (Avila, 2016).

\begin{tabular}{c|c|c}
\hline Barragem & Ano & Danos Principais \\
\hline $\begin{array}{c}\text { Fernandinho, } \\
\text { Rio Acima }\end{array}$ & 1986 & 7 mortes \\
\hline Rio Verde & 2001 & 5 mortes \\
\hline $\begin{array}{c}\text { Indústria de } \\
\text { Papel, } \\
\text { Cataguases }\end{array}$ & 2003 & $\begin{array}{c}\text { Lixívia negra liberada, interrupção de } \\
\text { fornecimento de água }\end{array}$ \\
\hline $\begin{array}{c}\text { Mineração Rio } \\
\text { Pomba, Miraí }\end{array}$ & 2006 & $\begin{array}{c}\text { Vazamento de rejeitos de bauxita. } \\
\text { Interrupção de fornecimento de água }\end{array}$ \\
\hline $\begin{array}{c}\text { Mineração Rio } \\
\text { Pomba, Miraí }\end{array}$ & 2007 & $\begin{array}{c}\text { Vazamento de rejeitos de bauxita. } \\
\text { Interrupção de fornecimento de água }\end{array}$ \\
\hline $\begin{array}{c}\text { Herculano, } \\
\text { Itabirito }\end{array}$ & 2014 & 3 mortes \\
\hline $\begin{array}{c}\text { Fundão, } \\
\text { Mariana }\end{array}$ & 2015 & 22 mortes \\
\hline
\end{tabular}


Como citado anteriormente uma das causas é a instabilidade do talude, o procedimento para a análise da estabilidade é o método determinístico de equilíbrio limite. Pela heterogeneidade natural dos materiais utilizados na construção das barragens de rejeitos, a utilização de métodos probabilísticos se apresenta como um modelo que considera as variações dos parâmetros de resistência, atuando como complemento à usual avaliação por fator de segurança.

Desta forma, a proposta dessa pesquisa foi estudar uma mistura utilizando material de rejeito (lignosulfonato) e solo como elemento estrutural da barragem e verificando se os parâmetros obtidos nos ensaios laboratoriais após simulação computacional apresentam fatores e resultados dentro do permitido na legislação. 


\section{OBJETIVOS}

Esta pesquisa teve como objetivo apresentar os fatores de segurança para aterros compactados com solo residual típico do Distrito Federal com e sem mistura de lignosulfonato de forma a compara-lo. Com o intuito de simular condições de baixo controle de compactação, foi estudado materiais para o corpo da barragem com mistura de solo-lignosulfonato para todos os teores de umidade compactado com os valores de $2 \%, 4 \%, 6 \%$ e com $8 \%$ de lignosulfonato baseado em estudos já realizados (Rezende et all, 2015). Baseado no estudo que os resultados desenvolvidos no laboratório demonstraram que a variação da estabilidade do aterro da barragem estudado, de acordo com a umidade de compactação, e que da inclinação sugerida para os taludes foram conservativas. 


\section{REVISÃO TEÓRICA}

\subsection{Legislação Barragens}

Segundo o Departamento Nacional de Produção Mineral - DNPM, a Lei № 12.334 , de 20 de setembro de 2010, estabelece a Política Nacional de Segurança de Barragens destinadas à acumulação de água para quaisquer usos, à disposição final ou temporária de rejeitos e à acumulação de resíduos industriais, cria o Sistema Nacional de Informações sobre Segurança de Barragens e altera a redação do art. 35 da Lei no 9.433, de 8 de janeiro de 1997, e do art. 4o da Lei no 9.984, de 17 de julho de 2000.

A resolução do Conselho Nacional de Recursos Hídricos - CNRH № 143, de 10 de julho de 2012 estabelece critérios gerais de classificação de barragens por categoria de risco, dano potencial associado e pelo volume do reservatório, em atendimento ao art. $7^{\circ}$ da Lei $n^{\circ}$ 12.334, de 20 de setembro de 2010 (DNPM, 2015). Considerando:

I - Barragem como qualquer estrutura em um curso permanente ou temporário de água para fins de contenção ou acumulação de substâncias líquidas ou de misturas de líquidos e sólidos, compreendendo o barramento e as estruturas associadas;

II - Reservatório local destinado para acumulação não natural de água, de substâncias líquidas ou de mistura de líquidos e sólidos.

Já para a classificação de barragens para disposição de resíduos e rejeito considera-se:

- a categoria de risco e

- dano potencial associado a forma de avaliar.

A Tabela 2 apresenta a matriz utilizada para a classificação de barragens para disposição de resíduo e rejeito podendo ser classificado como um dispositivo alto, médio e baixo risco e dano potencial associado. 
Tabela 2 - Matriz para classificação de barragens para disposição de resíduos e rejeitos (DNPM, 2015).

\begin{tabular}{|c|c|c|c|}
\hline \multicolumn{3}{|c|}{ I.1 - CATEGORIA DE RISCO } & \multirow[t]{2}{*}{ Pontos } \\
\hline 1 & \multicolumn{2}{|c|}{ Características Técnicas (CT) } & \\
\hline 2 & \multicolumn{2}{|c|}{ Estado de Conservação (EC) } & \\
\hline 3 & \multicolumn{2}{|c|}{ Plano de Segurança de Barragens (PS) } & \\
\hline \multicolumn{3}{|c|}{ PONTUAÇÃO TOTAL (CRI) = CT + EC + PS } & 0 \\
\hline & \multirow{4}{*}{ 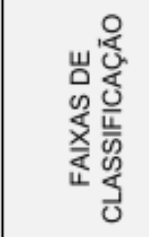 } & CATEGORIA DE RISCO & CRI \\
\hline & & ALTO & $>=60$ ou $\mathrm{EC}^{*}=10$ \\
\hline & & MÉdIO & 35 a 60 \\
\hline & & BAIXO & $<=35$ \\
\hline \multicolumn{4}{|c|}{$\begin{array}{l}\text { (") Pontuação (10) em qualquer coluna de Estado de Conservação (EC) implica automaticamente } \\
\text { CATEGORIA DE RISCO ALTA e necessidade de providencias imediatas pelo responsavel da barragem }\end{array}$} \\
\hline \multicolumn{3}{|c|}{ I.2 - DANO POTENCIAL ASSOCIADO } & Pontos \\
\hline & & DANO POTENCIAL ASSOCIADO (DPA) & \\
\hline & \multirow{4}{*}{ 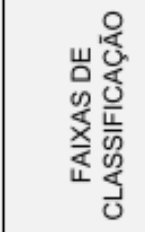 } & DANO POTENCIAL ASSOCIADO & DPA \\
\hline & & ALTO & $>=13$ \\
\hline & & MÉDIO & $7<$ DPA $<13$ \\
\hline & & BAIXO & $<=7$ \\
\hline
\end{tabular}

Para a avaliação da categoria de risco se faz a somatória dos pontos referente a:

- Característica técnica (CT) que se refere ao somatório de pontos quanto a geometria e ao cálculo da vazão de projeto (Tabela 3); 
Tabela 3 - Característica técnica CT - (DNPM, 2015).

\begin{tabular}{|c|c|c|}
\hline Altura (a) & Comprimento (b) & Vazão de Projeto ( c) \\
\hline $\begin{array}{l}\text { Altura } \leq 15 \mathrm{~m} \\
\quad(0)\end{array}$ & $\begin{array}{l}\text { Comprimento } \leq 50 \mathrm{~m} \\
(0)\end{array}$ & $\begin{array}{c}\text { CMP (Cheia Máxima Provável) ou } \\
\text { Decamilenar } \\
(0)\end{array}$ \\
\hline $\begin{array}{c}15 \mathrm{~m}<\text { Altura }<30 \mathrm{~m} \\
\text { (1) }\end{array}$ & $\begin{array}{c}50 \mathrm{~m}<\text { Comprimento }<200 \mathrm{~m} \\
\text { (1) }\end{array}$ & $\begin{array}{l}\text { Milenar } \\
(2)\end{array}$ \\
\hline $\begin{array}{c}30 \mathrm{~m} \leq \text { Altura } \leq 60 \mathrm{~m} \\
(4)\end{array}$ & $\begin{array}{c}200 \leq \text { Comprimento } \leq 600 \mathrm{~m} \\
\text { (2) }\end{array}$ & $\mathrm{TR}=500$ anos \\
\hline $\begin{array}{c}\text { Altura }>60 \mathrm{~m} \\
(7)\end{array}$ & $\begin{array}{l}\text { Comprimento }>600 \mathrm{~m} \\
\text { (3) }\end{array}$ & $\begin{array}{c}\text { TR Inferior a } 500 \text { anos ou Desconhecida/ } \\
\text { Estudo não confiavel } \\
\text { (10) }\end{array}$ \\
\hline
\end{tabular}

- Estado de conservação (EC), somatório de pontos quanto as considerações de controle das barragens (Tabela 4);

Tabela 4 - Estado de conservação - EC (DNPM, 2015).

\begin{tabular}{|c|c|c|c|}
\hline $\begin{array}{l}\text { Confiabilidade das Estruturas } \\
\text { Extravasoras } \\
\text { (d) }\end{array}$ & $\begin{array}{l}\text { Percolação } \\
\text { (e) }\end{array}$ & $\begin{array}{l}\text { Deformações e Recalques } \\
\text { (f) }\end{array}$ & $\begin{array}{c}\text { Deterioração dos Taludes I } \\
\text { Paramentos } \\
\text { (g) }\end{array}$ \\
\hline $\begin{array}{l}\text { Estruturas civis bem mantidas e em } \\
\text { operação normal /barragem sem } \\
\text { necessidade de estruturas } \\
\text { extravasoras } \\
(0)\end{array}$ & $\begin{array}{l}\text { Percolação totalmente controlada } \\
\text { pelo sistema de drenagem } \\
\text { (0) }\end{array}$ & $\begin{array}{l}\text { Não existem deformações e } \\
\text { recalques com potencial de } \\
\text { comprometimento da segurança da } \\
\text { estrutura } \\
(0)\end{array}$ & $\begin{array}{c}\text { Não existe deterioração de taludes e } \\
\text { paramentos } \\
(0)\end{array}$ \\
\hline $\begin{array}{c}\text { Estruturas com problemas } \\
\text { identificados e medidas corretivas } \\
\text { em implantação } \\
\text { (3) }\end{array}$ & $\begin{array}{l}\text { Umidade ou surgência nas áreas de } \\
\text { jusante, paramentos, taludes e } \\
\text { ombreiras estáveis e monitorados } \\
\text { (3) }\end{array}$ & $\begin{array}{c}\text { Existência de trincas e abatimentos } \\
\text { com medidas corretivas em } \\
\text { implantação } \\
(2)\end{array}$ & $\begin{array}{c}\text { Falhas na proteção dos taludes e } \\
\text { paramentos, presença de vegetação } \\
\text { arbustiva } \\
\text { (2) }\end{array}$ \\
\hline $\begin{array}{l}\text { Estruturas com problemas } \\
\text { identificados e sem implantação das } \\
\text { medidas corretivas necessárias } \\
\text { (6) }\end{array}$ & $\begin{array}{l}\text { Umidade ou surgência nas áreas de } \\
\text { jusante, paramentos, taludes ou } \\
\text { ombreiras sem implantação das } \\
\text { medidas corretivas necessárias } \\
\text { (6) }\end{array}$ & $\begin{array}{c}\text { Existência de trincas e abatimentos } \\
\text { sem implantação das medidas } \\
\text { corretivas necessárias } \\
(6)\end{array}$ & $\begin{array}{l}\text { Erosões superficiais, ferragem } \\
\text { exposta, presença de vegetação } \\
\text { arbórea, sem implantação das } \\
\text { medidas corretivas necessárias } \\
(6)\end{array}$ \\
\hline $\begin{array}{c}\text { Estruturas com problemas } \\
\text { identificados, com redução de } \\
\text { capacidade vertente e sem medidas } \\
\text { corretivas } \\
(10)\end{array}$ & $\begin{array}{c}\text { Surgência nas áreas de jusante com } \\
\text { carreamento de material ou com } \\
\text { vazão crescente ou infiltração do } \\
\text { material contido, com potencial de } \\
\text { comprometimento da segurança da } \\
\text { estrutura } \\
(10)\end{array}$ & $\begin{array}{c}\text { Existência de trincas, abatimentos } \\
\text { ou escorregamentos, com potencial } \\
\text { de comprometimento da segurança } \\
\text { da estrutura } \\
(10)\end{array}$ & $\begin{array}{c}\text { Depressões acentuadas nos taludes, } \\
\text { escorregamentos, sulcos profundos } \\
\text { de erosão, com potencial de } \\
\text { comprometimento da segurança da } \\
\text { estrutura. } \\
(10)\end{array}$ \\
\hline
\end{tabular}


- Plano de segurança de barragens (PS) somatório de pontos quanto as documentações, estrutura organizacional, manuais, plano de ação e relatórios de inspeção (Tabela 5);

Tabela 5 - Plano de segurança de barragens - OS (DNPM, 2015).

\begin{tabular}{|c|c|c|c|c|}
\hline $\begin{array}{l}\text { Documentação de Projeto } \\
\text { (h) }\end{array}$ & $\begin{array}{c}\text { Estrutura Organizacional e } \\
\text { Qualificação dos Profissionais na } \\
\text { Equipe de Segurança da Barragem } \\
\text { (i) }\end{array}$ & $\begin{array}{l}\text { Manuais de Procedimentos para } \\
\text { Inspeçöes de Segurança e } \\
\text { Monitoramento } \\
\text { (j) }\end{array}$ & $\begin{array}{c}\text { Plano de Açăo Emergencial - PAE } \\
\text { (quando exigido pelo órgão } \\
\text { fiscalizador) } \\
\text { (k) }\end{array}$ & $\begin{array}{c}\text { Relatórios de inspeção e } \\
\text { monitoramento da instrumentação } \\
\text { e de Análise de Segurança } \\
\text { (I) }\end{array}$ \\
\hline $\begin{array}{l}\text { Projeto executivo e "como } \\
\text { construido" } \\
(0)\end{array}$ & $\begin{array}{c}\text { Possui unidade administrativa com } \\
\text { profissional técnico qualificado } \\
\text { responsável pela segurança da } \\
\text { barragem } \\
(0)\end{array}$ & $\begin{array}{l}\text { Possui manuais de procedimentos } \\
\text { para inspeção, monitoramento e } \\
\text { operação } \\
(0)\end{array}$ & $\begin{array}{l}\text { Possui PAE } \\
\text { (0) }\end{array}$ & $\begin{array}{l}\text { Emite regularmente relatórios de } \\
\text { inspeção e monitoramento com base } \\
\text { na instrumentação e de Análise de } \\
\text { Segurança } \\
(0)\end{array}$ \\
\hline $\begin{array}{l}\text { Projeto executivo ou "como } \\
\text { construido" } \\
\text { (2) }\end{array}$ & $\begin{array}{l}\text { Possui profissional técnico } \\
\text { qualificado (próprio ou contratado) } \\
\text { responsável pela segurança da } \\
\text { barragem } \\
\text { (1) }\end{array}$ & $\begin{array}{l}\text { Possui apenas manual de } \\
\text { procedimentos de monitoramento } \\
\text { (2) }\end{array}$ & $\begin{array}{c}\text { Não possui PAE (nāo é exigido pelo } \\
\text { órgão fiscalizador) } \\
\text { (2) }\end{array}$ & $\begin{array}{l}\text { Emite regularmente apenas } \\
\text { relatórios de Análise de Segurança } \\
\text { (2) }\end{array}$ \\
\hline $\begin{array}{l}\text { Projeto básico } \\
\text { (5) }\end{array}$ & $\begin{array}{l}\text { Possui unidade administrativa sem } \\
\text { profissional técnico qualificado } \\
\text { responsável pela segurança da } \\
\text { barragem } \\
\text { (3) }\end{array}$ & $\begin{array}{l}\text { Possui apenas manual de } \\
\text { procedimentos de inspeção } \\
\text { (4) }\end{array}$ & $\begin{array}{l}\text { PAE em elaboração } \\
\text { (4) }\end{array}$ & $\begin{array}{l}\text { Emite regularmente apenas } \\
\text { relatórios de inspeção e } \\
\text { monitoramento } \\
\text { (4) }\end{array}$ \\
\hline $\begin{array}{l}\text { Projeto conceitual } \\
\text { (8) }\end{array}$ & $\begin{array}{c}\text { Não possui unidade administrativa e } \\
\text { responsável técnico qualificado pela } \\
\text { segurança da barragem } \\
\text { (6) }\end{array}$ & $\begin{array}{l}\text { Não possui manuais ou } \\
\text { procedimentos formais para } \\
\text { monitoramento e inspeçōes } \\
\text { (8) }\end{array}$ & $\begin{array}{c}\text { Não possui PAE (quando for exigido } \\
\text { pelo órgâa fiscalizador) } \\
\text { (8) }\end{array}$ & $\begin{array}{l}\text { Emite regularmente apenas } \\
\text { relatórios de inspeçăo visual } \\
\qquad(6)\end{array}$ \\
\hline $\begin{array}{l}\text { Não há documentação de projeto } \\
\text { (10) }\end{array}$ & $\cdot$ & - & - & $\begin{array}{c}\text { Não emite regularmente relatórios de } \\
\text { inspeção e monitoramento e de } \\
\text { Análise de Segurança } \\
\text { (8) }\end{array}$ \\
\hline
\end{tabular}

Segundo a Resolução № 143, de 10 de julho de 2012 do Conselho Nacional de Recursos Hídricos - $\mathrm{CNRH}$, utilizam os critérios gerais a serem utilizados para classificação quanto ao dano potencial associado na área afetada são:

I - Existência de população a jusante com potencial de perda de vidas humanas;

II - Existência de unidades habitacionais ou equipamentos urbanos ou comunitários;

III - Existência de infraestrutura ou serviços;

IV - Existência de equipamentos de serviços públicos essenciais;

V - Existência de áreas protegidas definidas em legislação;

VI - Natureza dos rejeitos ou resíduos armazenados; e

VII - Volume. 
Para a classificação de barragens para disposição de rejeito mineral e/ou resíduo industrial, quanto ao volume do reservatório, considerar-se-á:

I - Muito pequeno: reservatório com volume total inferior ou igual a 500 mil metros cúbicos;

II - Pequena: reservatório com volume total superior a 500 mil metros cúbicos e inferior ou igual a 5 milhões de metros cúbicos;

III - Média: reservatório com volume total superior a 5 milhões de metros cúbicos e inferior ou igual a 25 milhões de metros cúbicos;

IV - Grande: reservatório com volume total superior a 25 milhões e inferior ou igual a 50 milhões de metros cúbicos; e

V - Muito grande: reservatório com volume total superior a 50 milhões de metros cúbicos.

Para a classificação de barragens para acumulação de água, quanto ao volume de seu reservatório, considerar-se-á:

I - Pequena: reservatório com volume inferior ou igual a 5 milhões de metros cúbicos;

II - Média: reservatório com volume superior a 5 milhões de metros cúbicos e inferior ou igual a 75 milhões de metros cúbicos;

III - Grande: reservatório com volume superior a 75 milhões de metros cúbicos e inferior ou igual a 200 milhões de metros cúbicos; e

IV - Muito grande: reservatório com volume superior a 200 milhões de metros cúbicos.

A Tabela 6 apresenta o quadro para a classificação quanto ao dano potencial associado - DPA (Resíduo e Rejeitos). O valor do dano potencial associado é a somatória dos pontos referente ao volume total do reservatório (a), da existência de população a jusante (b), do impacto ambiental (c) e do impacto sócio-econômico (d) com o volume do reservatório. 
Tabela 6 - Quadro de classificação quanto ao dano potencial associado - DPA (Resíduo e Rejeitos)

\begin{tabular}{|c|c|c|c|}
\hline $\begin{array}{l}\text { Volume Total do Reservatório } \\
\text { (a) }\end{array}$ & $\begin{array}{l}\text { Existência de populaçăo a jusante } \\
\text { (b) }\end{array}$ & $\begin{array}{l}\text { Impacto ambiental } \\
\text { (c) }\end{array}$ & $\begin{array}{l}\text { Impacto sócio-econômico } \\
\text { (d) }\end{array}$ \\
\hline $\begin{array}{c}\text { Muito Pequeno } \\
<=500 \mathrm{mil} \mathrm{m}^{3} \\
\text { (1) }\end{array}$ & \begin{tabular}{|c|} 
INEXISTENTE \\
(não existem pessoas \\
permanentes/residentes ou \\
temporárias/transitando na área afetada a \\
jusante da barragem) \\
(0)
\end{tabular} & \begin{tabular}{|c|} 
INSIGNIFICANTE \\
(área afetada a jusante da barragem \\
encontra-se totalmente descaracterizada de \\
suas condiçōes naturais e a estrutura \\
armazena apenas residuos Classe II B - \\
Inertes, segundo a NBR 10.004 da ABNT ) \\
$(0)$
\end{tabular} & $\begin{array}{c}\text { INEXISTENTE } \\
\text { ( nāo existem quaisquer instalaçōes na } \\
\text { área afetada a jusante da barragem) } \\
(0)\end{array}$ \\
\hline $\begin{array}{l}\text { Pequeno } 500 \text { mil a } 5 \text { milhōes } \mathrm{m}^{2} \\
\text { (2) }\end{array}$ & \begin{tabular}{|c|} 
POUCO FREQUENTE \\
(não existem pessoas ocupando \\
permanentemente a área afetada a \\
jusante da barragem, mas existe estrada \\
vicinal de uso local) \\
(3)
\end{tabular} & \begin{tabular}{|c|} 
POUCO SIGNIFICATIVO \\
( área afetada a jusante da barragem năo \\
apresenta área de interesse ambiental \\
relevante ou áreas protegidas em legislaçāo \\
especifica, excluidas APPs, e armazena \\
apenas residuos Classe II B - Inertes \\
segundo a NBR 10.004 da ABNT ) \\
(2)
\end{tabular} & $\begin{array}{c}\text { BAIXO } \\
\text { (existe pequena concentração de } \\
\text { instalaçōes residenciais, agricolas, } \\
\text { industriais ou de infra-estrutura de } \\
\text { relevăncia sócio-econômico-cultural na } \\
\text { área afetada a jusante da barragem) } \\
\text { (1) }\end{array}$ \\
\hline $\begin{array}{l}\text { Médio } 5 \text { milhőes a } 25 \text { milhōes } m^{3} \\
\text { (3) }\end{array}$ & \begin{tabular}{|c|} 
FREQUENTE \\
( năo existem pessoas ocupando \\
permanentemente a área afetada a \\
jusante da barragem, mas existe rodovia \\
municipal ou estadual ou federal ou outro \\
local e/ou empreendimento de \\
permanência eventual de pessoas que \\
poderăo ser atingidas) \\
(5)
\end{tabular} & $\begin{array}{c}\text { SIGNIFICATIVO } \\
\text { (área afetada a jusante da barragem } \\
\text { apresenta área de interesse ambiental } \\
\text { relevante ou áreas protegidas em legislaçăo } \\
\text { especifica, excluidas APPs,e armazena } \\
\text { apenas residuos Classe II B - Inertes, } \\
\text { segundo a NBR 10.004 da ABNT) } \\
\text { (6) }\end{array}$ & $\begin{array}{c}\text { MÉDIO } \\
\text { (existe moderada concentração de } \\
\text { instalaçóes residenciais, agricolas, } \\
\text { industriais ou de infra-estrutura de } \\
\text { relevância sócio-económico-cultural na } \\
\text { área afetada a jusante da barragem) } \\
\text { (3) }\end{array}$ \\
\hline $\begin{array}{l}\text { Grande } 25 \text { milhōes a } 50 \text { milhōes } m^{3} \\
\text { (4) }\end{array}$ & $\begin{array}{c}\text { EXISTENTE } \\
\text { ( existem pessoas ocupando } \\
\text { permanentemente a área afetada a } \\
\text { jusante da barragem, portanto, vidas } \\
\text { humanas poderāo ser atingidas) } \\
\text { (10) }\end{array}$ & $\begin{array}{c}\text { MUITO SIGNIFICATIVO } \\
\text { ( barragem armazena rejeitos ou resíduos } \\
\text { sólidos classificados na Classe II A - Não } \\
\text { Inertes, segundo a NBR } 10004 \text { da ABNT) } \\
\text { (8) }\end{array}$ & $\begin{array}{l}\text { ALTO } \\
\text { (existe alta concentraçâa de instalaçбes } \\
\text { residenciais, agricolas, industriais ou de } \\
\text { infra-estrutura de relevância sóio- } \\
\text { económico-cultural na área afetada a } \\
\text { jusante da barragem) } \\
\text { (5) }\end{array}$ \\
\hline $\begin{array}{l}\text { Muito Grande } \\
>=50 \text { milhøes } \mathrm{m}^{3} \\
(5)\end{array}$ & $\cdot$ & $\begin{array}{c}\text { MUITO SIGNIFICATIVO AGRAVADO } \\
\text { (barragem armazena rejeitos ou residuos } \\
\text { solidos classificados na Classe I- Perigosos } \\
\text { segundo a NBR 10004 da ABNT) } \\
\text { (10) }\end{array}$ & - \\
\hline
\end{tabular}

Resolução no 144, de 10 de julho de 2012, estabelece diretrizes para implementação da Política Nacional de Segurança de Barragens, aplicação de seus instrumentos e atuação do Sistema Nacional de Informações sobre Segurança de Barragens, em atendimento ao art. 20 da Lei $n^{\circ}$ 12.334, de 20 de setembro de 2010, que alterou 0 art. 35 da Lei oㅜ 9.433, de 8 de janeiro de 1997 (DNPM, 2015).

A Portaria oㅜ 14, de 15 de janeiro 2016, estabelece o prazo para apresentação de comprovante de entrega das cópias físicas do Plano de Ação de Emergência de Barragem de Mineração (PAEBM) para as Prefeituras e Defesas Civis municipais e estaduais, conforme exigido pelo art. $7^{0}$ da Portaria $n^{\circ} 526$, de 2013 , e dá outras providências (DNPM, 2015). 
A Portaria no 70.389, de 17 de maio de 2017, cria o Cadastro Nacional de Barragens de Mineração, o Sistema Integrado de Gestão em Segurança de Barragens de Mineração e estabelece a periodicidade de execução ou atualização, a qualificação dos responsáveis técnicos, o conteúdo mínimo e o nível de detalhamento do Plano de Segurança da Barragem, das Inspeções de Segurança Regular e Especial, da Revisão Periódica de Segurança de Barragem e do Plano de Ação de Emergência para Barragens de Mineração, conforme art. $8^{\circ}, 9^{\circ}, 10,11$ e 12 da Lei $n^{\circ} 12.334$ de 20 de setembro de 2010, que estabelece a Política Nacional de Segurança de Barragens - PNSB (DNPM, 2015).

\subsection{Lignosulfonato}

O principal processo químico de extração do Lignosulfonato também conhecido como lignina e chamado de kraft, rejeito numa das etapas da fabricação do papel. A O Lignosulfonato é um subproduto da indústria de celulose que possui propriedades aglutinante de partículas .

Figura 1 apresenta os valores do potencial de aplicação como alto valor de agregado da lignina kraft. O Lignosulfonato é um subproduto da indústria de celulose que possui propriedades aglutinante de partículas (Schmidt, et al., 2004).

Figura 1 - Potencial de Mercado - Lignina (2011)

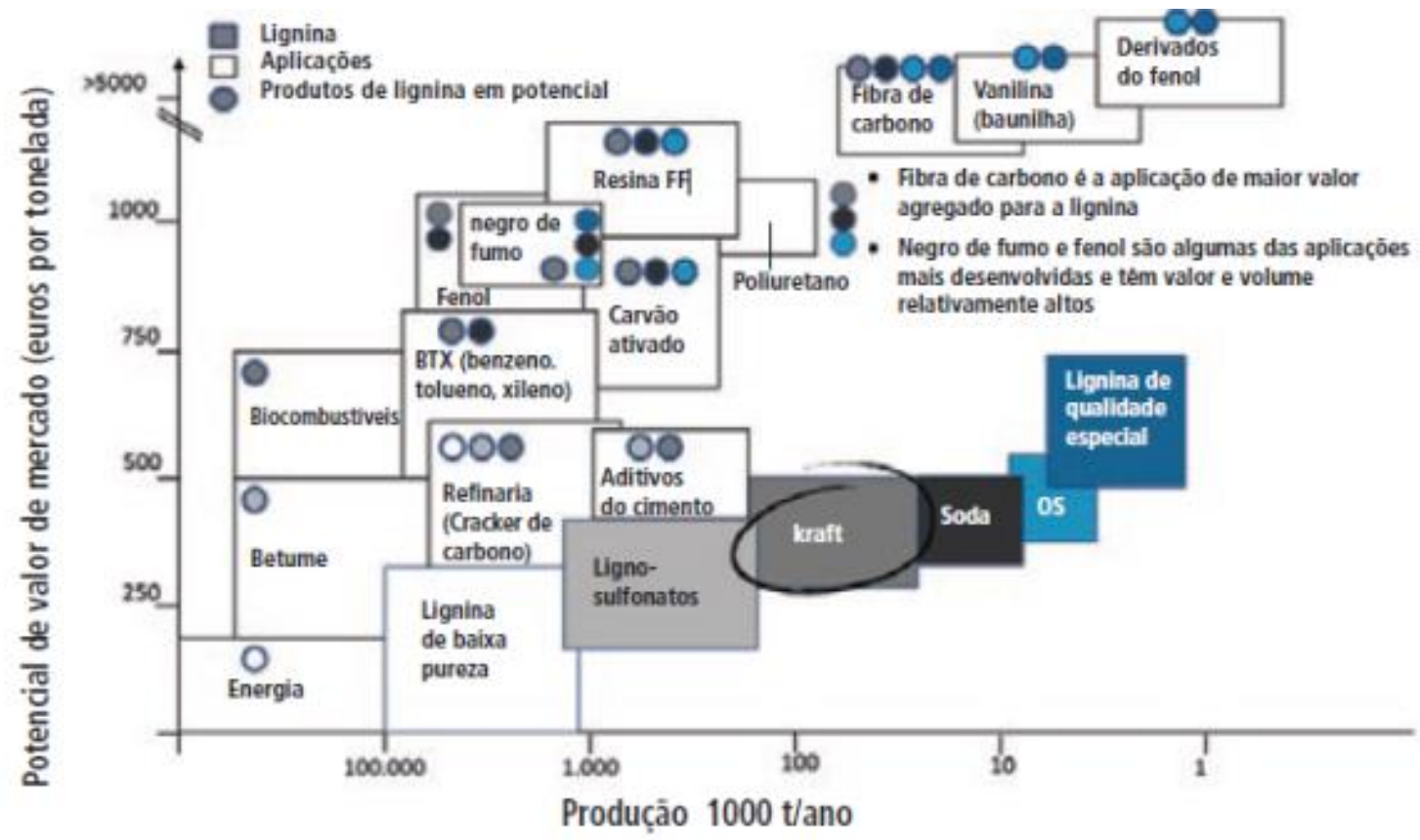

Nota: OS =Solvente orgănico Lignina (Organosolve) 1- Licor negro e não fermentáveis Fonte: Gosselink; "Desafios nas aplicaçōes industriais da lignina técnica" 
Fonte: (Celulose Online, 2016).

Para a extração da lignina, ocorre primeiro a transformação da madeira em polpa, e após essa etapa ocorre a separação da lignina, a celulose e a hemicelulose que constituem a parede celular da madeira (Figura 2). Para a etapa de separação existem vários processos, sendo os principais os processos mecânicos e os químicos (FARIAS, 2013).

Figura 2 - Estrutura da parede celular vegetal.

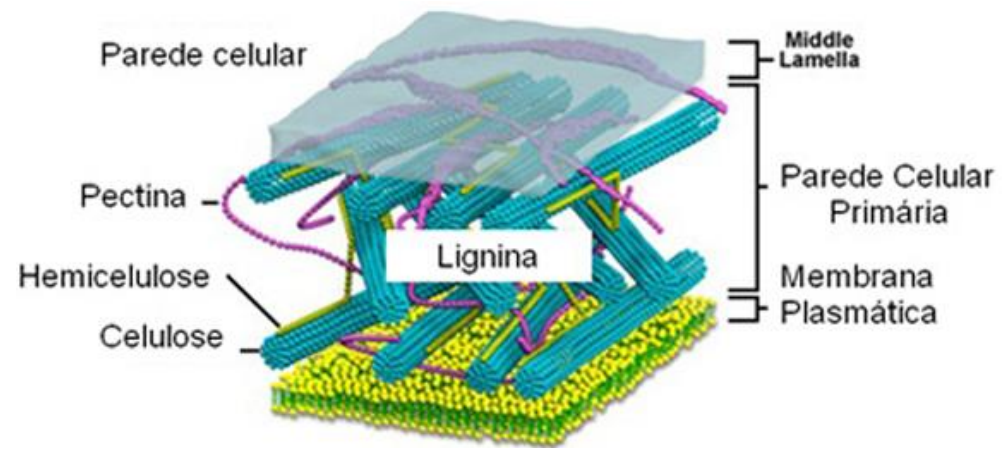

Fonte: (Celulose Online, 2016).

Segundo Farias (2013) os processos mecânicos basicamente trituram a madeira, separando apenas a hemicelulose, e assim produzindo uma polpa de menor qualidade, de fibras curtas e amarelado. Com isso, o método kraft, que trata a madeira em cavacos com hidróxido de sódio e hidrossulfeto de sódio, que dissolve a lignina, liberando a celulose como polpa de papel de maior qualidade.

Segundo Klock at al. (2005), para análise dos componentes da madeira, os principais componentes macromoleculares constituintes da parede celular são:

- Celulose

- Polioses (hemiceluloses), e

- Lignina.

Esses elementos estão presentes em todas as madeiras. A Tabela 7 apresenta os componentes minoritários de baixo peso molecular, extrativos e substâncias minerais, os quais são geralmente mais relacionados a madeira de certas espécies, no tipo e quantidade. As proporções e composição química da lignina e polioses 
diferem em coníferas e folhosas, enquanto que a celulose é um componente uniforme da madeira (KLOCK AT AL., 2005 ).

Tabela 7 - Composição média de madeira de coníferas e folhosas.

\begin{tabular}{c|c|r}
\hline Constituinte & Coníferas & Folhosas \\
\hline Celulose & $42 \pm 2 \%$ & $45 \pm 2 \%$ \\
\hline Polioses & $27 \pm 2 \%$ & $30 \pm 5 \%$ \\
\hline Lignina & $28 \pm 2 \%$ & $20 \pm 4 \%$ \\
\hline Extrativos & $5 \pm 3 \%$ & $3 \pm 2 \%$ \\
\hline
\end{tabular}

Fonte: Klock at al. (2005)

Segundo Klock at al. (2005) a morfológico da lignina é uma substância amorfa localizada na lamela média composta, bem como na parede secundária. Durante o desenvolvimento das células, a lignina é incorporada como o último componente na parede, interpenetrando as fibrilas e assim fortalecendo, enrijecendo as paredes celulares, proporcionando rigidez às plantas.

De acordo com Kaliyan e Morey (2009) na indústria alimentícia, a lignina é usada como aglutinante a fim de melhorar a qualidade de péletes (ração) na alimentação de animais. Porem Per Tomani, Svard e Amand (2008), destacam a importância também para geração de biocombustíveis.

\subsection{Barragens de rejeitos e mineração}

Segundo Rezende (2013), a engenharia e a mineração sempre estiveram interligadas pela procura da exploração de minério, da forma mais eficiente e menos poluidora possível. Com o aumento do consumo dessa matéria-prima, em escala mundial, aumentou-se a exploração e, por consequência, a geração de rejeitos provenientes desta. Coube então à engenharia e, em especial, à geotecnia, a missão de possibilitar a contenção ou armazenamento desses rejeitos, através das denominadas barragens de rejeito, o que representou e representa um continuo desafio, na medida em que estas vêm aumentando seu porte ao longo dos anos e porque apresentariam consequências catastróficas em caso de ruptura.

A mineração é um complexo de atividades necessárias à extração econômica de bens minerais, provocando transformações no meio ambiente, através de atividades 
de lavra que constitui no conjunto de atividades que extraem um bem mineral, objetivando o seu aproveitamento industrial ou uso direto e s processos de mineração (tratamentos) envolvem separações físicas e químicas para obtenção da substância mineral de interesse (Espósito, 2000).

O beneficiamento de minérios é o tratamento industrial que prepara granulometricamente, purifica ou enriquece minérios por métodos físicos ou químicos, sem alteração da constituição química dos minerais. Este divide o mineral bruto em concentrado e rejeito. A polpa que decorre do processo não apresenta valor econômico e é disposta como rejeito no sistema de armazenamento, geralmente sendo contida por diques ou barragens. A mineração é uma atividade que, então, gera um grande volume de rejeitos, devido à pequena concentração de metal encontrada no mineral bruto (Rezende, 2013).

Atualmente a disposição de rejeitos tem sido um aspecto muito focalizado nos estudos de uma empresa de mineração. A segurança e o perfeito funcionamento destes sistemas são fundamentais para a contínua realização das atividades minerais. Como alternativa para construção de sistemas de disposição e contenção de rejeitos as empresas têm utilizado o próprio rejeito como elemento de construção destas estruturas, diminuindo o custo na construção das mesmas, aumentando sua capacidade de armazenamento e possibilitando a construção em fases, juntamente com o avanço de lavra (Araujo, 2006).

Já os rejeitos são partículas resultantes de processos de beneficiamento dos minérios visando extrair os elementos mais importantes economicamente. Os procedimentos adotados para essa extração são variados, pois dependem do tipo e da qualidade desejada para o minério a ser extraído. A constituição dos rejeitos é caracterizada pela presença de uma fração líquida e sólida, com concentração de $30 \%$ a $50 \%$ em peso, apresentando características que são função do minério bruto e do processo industrial utilizado no beneficiamento (Rezende, 2013).

Em função do tipo de minério e do tratamento utilizado, os rejeitos podem variar de materiais arenosos não plásticos (rejeitos granulares) até solos de granulometria fina (lamas). Os rejeitos granulares, constituídos de partículas de granulometria de areias finas a médias, não plásticas, possuem alta permeabilidade e resistência ao 
cisalhamento e baixa compressibilidade. Já as lamas, constituídas por partículas de granulometria de siltes e argilas, possuem difícil sedimentação e alta compressibilidade (Araujo, 2006).

\subsection{Modelos construtivos de barragens de rejeitos}

A construção e os posteriores alteamentos das barragens de rejeitos podem assumir diferentes configurações e características, onde cada método possui suas vantagens de desvantagens. Existem três diferentes configurações cujo nome refere-se à direção tomada pelos alteamentos em relação ao dique de partida (Rezende, 2013).

O método de montante é o mais antigo, simples e econômico. A etapa inicial na execução deste tipo de barragem consiste na construção de um dique de partida, normalmente maior que os diques das demais etapas, sendo de material argiloso ou enrocamento compactado. Após realizada esta etapa, o rejeito é lançado por canhões em direção a montante da linha de simetria do dique, ao longo do perímetro deste, formando assim a praia de deposição, que se tornará a fundação e eventualmente fornecerá material de construção para o próximo alteamento. Como os rejeitos têm distribuição granulométrica ampla, as partículas mais grossas permanecem próximas ao dique de partida e as partículas mais finas ficam em suspensão e são transportadas para as zonas internas da bacia de sedimentação. Este processo continua sucessivamente, com diques sendo construídos em todo o perímetro da bacia até que a cota final, determinada pelas necessidades operacionais da mina, seja atingida (Figura 3).

Figura 3 - Alteamento pelo método de montante.

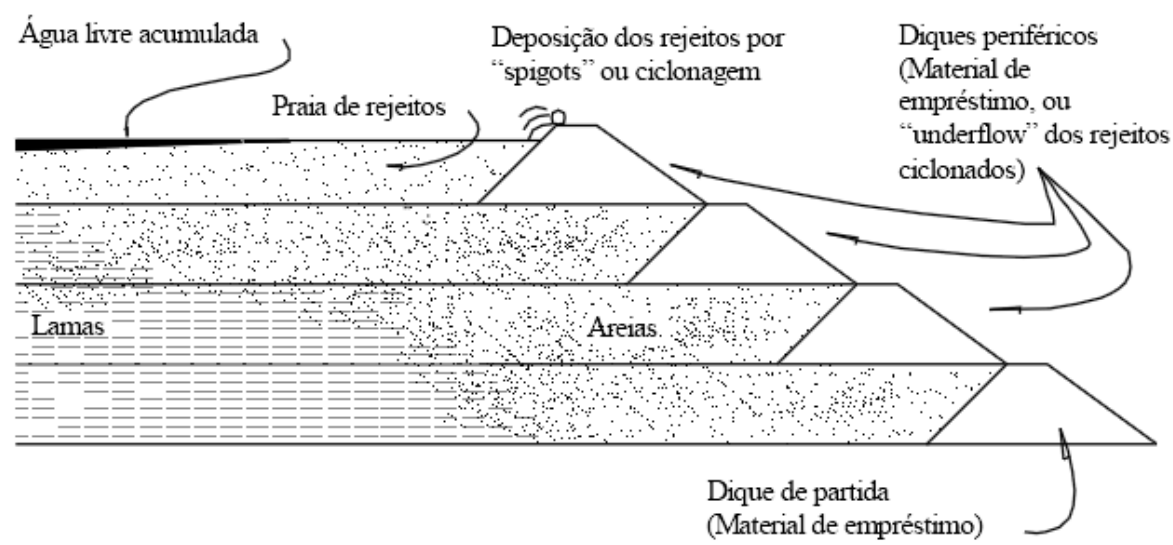

Fonte: Lozano (2006). 
No método de jusante, a etapa inicial consiste na construção de um dique de partida, normalmente de solo ou enrocamento compactado. Depois de realizada esta etapa, os alteamentos subsequentes são realizados para jusante do dique de partida. Este processo continua sucessivamente até que a cota final prevista em projeto seja atingida (Figura 4).

Figura 4 - Alteamento pelo método de jusante.

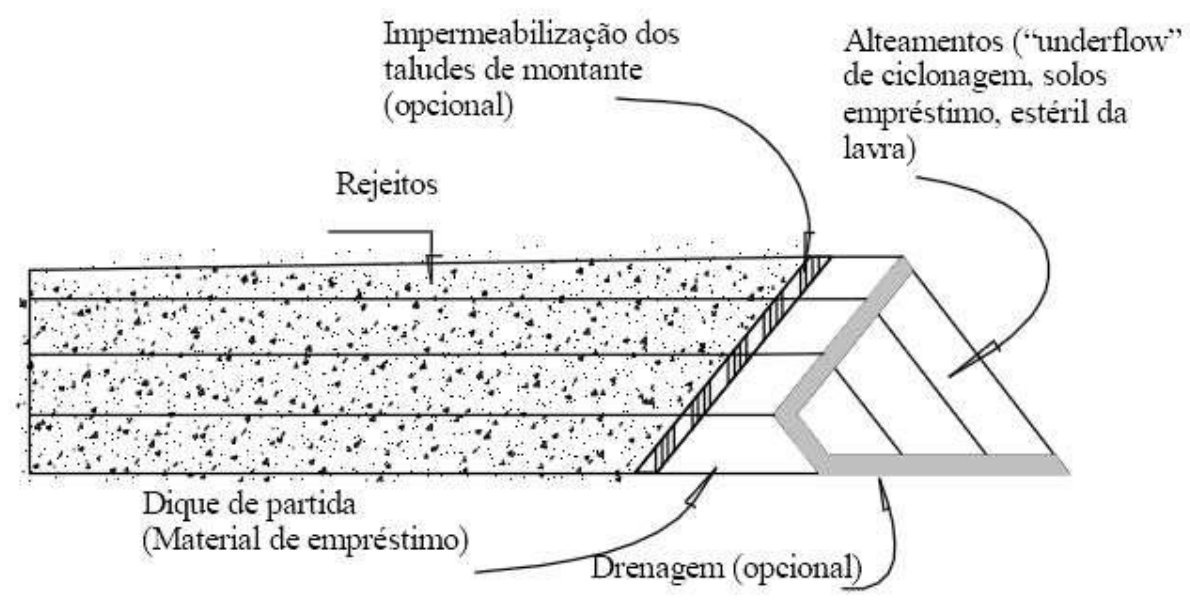

Fonte: Lozano (2006).

Barragens alteadas pelo método de linha de centro apresentam uma solução intermediária entre os dois métodos citados anteriormente, apresentando vantagens dos dois métodos anteriores, tentando minimizar suas desvantagens. Apesar disso, seu comportamento geotécnico se assemelha mais a barragens alteadas para jusante, tornando-se uma variação deste método, onde o alteamento da crista é realizado de forma vertical, sendo o eixo vertical dos alteamentos coincidente com o eixo do dique de partida (Figura 5).

Figura 5 - Alteamento pelo método de linha de centro.

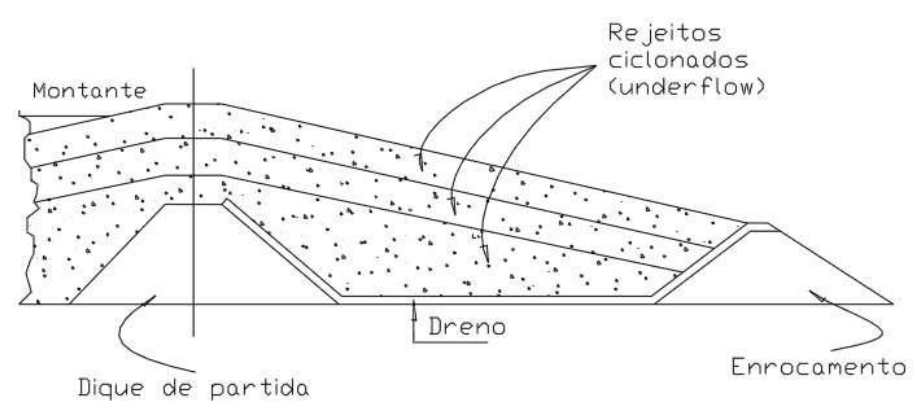

Fonte: Lozano (2006). 
Neste método, o rejeito é lançado perifericamente da crista do dique até formar uma praia. O alteamento subsequente é formado lançando materiais de empréstimo, estéril ou "underflow", sobre o limite da praia anterior e no talude de jusante do maciço de partida. É possível então a utilização de zonas de drenagem internas em todas as fases de alteamento, o que possibilita o controle da linha de saturação. Este controle promove uma dissipação de poropressões tornando o método apropriado para utilização inclusive em áreas de alta sismicidade (Rezende, 2013).

\subsection{Estabilidade de talude em barragens de terra}

Cada vez mais vem crescendo a disponibilidade computacional na sistemática de cálculo da estabilidade de taludes em solos. Análise mais gerais e abrangentes podem agora ser executadas, incluindo considerações do ponto de vista mecânico que não poderiam ser desenvolvidos sem o auxílio de computadores e métodos numérico. A técnica computacional vem influenciando nas análises de problemas ou possibilidades de estabilidade de taludes nos aspectos da variabilidade de superfícies potenciais de deslizamento com a localização da superfície critica com alto grau de confiança. E a possibilidade de utilizar métodos de cálculos mais avançados que satisfaz todas as condições do modelo.

No caso de barragens, a análise de estabilidade pelo método dos elementos finitos seria em princípio recomenda quanto o fator de segurança calculado pelo método de equilíbrio limite for inferior a 1,5, quando parâmetro de projeto e do método de cálculo deve ser revisto visando a segurança da obra. O método de equilíbrio limite para análise de estabilidade de taludes são amplamente utilizados e a experiência acumulada ao longo de anos tem demonstrado que são rápidos, precisos e simples. Esse método apresenta as seguintes características comuns:

- Usam como definição para o fator de segurança local a relação entre a resistência ao cisalhamento dividido pela resistência cisalhante atuante;

- Consideram como hipótese genérica que os maciços de solos se comportam mecanicamente como materiais rígidos-perfeitamente plásticos;

- Usam algumas ou todas as equações de equilíbrio para calcular valores médios de tensão cisalhante mobilizada e tensão normal ao longo da potencial 
superfície de ruptura, necessário para estimar a resistência ao cisalhamento pelo método de Mohr-Coulomb;

- Introduzem hipótese para complementar as equações de equilíbrio, visto que o número de incógnitas do problema é geralmente superior ao número de equações fornecidas pela estática.

Escorregamento é utilizado para classificar toda e qualquer movimentação, de relativa curta duração, de massas de terrenos geralmente bem definidas quanto ao volume, independentemente do processo, causa, velocidade, forma e outras características Fonte bibliográfica inválida especificada.

A necessidade de determinar uma grandeza que possibilitasse melhor compreensão tanto do comportamento estável, quanto de sensibilidade à ruptura, de um talude, devido a agentes condicionantes, estimulou a criação de diversos métodos de análise de estabilidade, desde os tradicionais que adotam o equilíbrio-limite até os mais recentes, os baseados em probabilidade (Rezende, 2013).

Os taludes das barragens de rejeitos, alvo do presente estudo, são, em geral, compostos dos materiais estéreis provenientes da extração do minério, do solo, ou dos rejeitos gerados. Os parâmetros geotécnicos desses materiais (peso específico, coesão efetiva, ângulo de atrito, permeabilidade, etc.), juntamente com a piezometria (influenciada pelo regime de chuvas, de evaporação e geração de resíduos) da região, possível ocorrência de sismicidade e possíveis sobrecargas no corpo da barragem são os condicionantes principais da segurança dessas estruturas, sendo estas condições retratadas nos estudos de estabilidade (Rezende, 2013). 


\section{MATERIAIS E METODOLOGIA DE TRABALHO}

No capitulo 4 tem-se a classificação e a descrição de todos os materiais utilizados nesta pesquisa. Além do mais, tem como objetivo apresentar o método específico para a realização de cada ensaio executado. Já os resultados obtidos serão apresentados ao decorrer do capítulo 5.

\subsection{Materiais Utilizados}

\subsubsection{Localização da retirada de amostra do solo}

A coleta das amostras deformadas de solo utilizadas nos ensaios foi realizada nos dias 08/08/2016 (segunda feira), 23/08/2016 (terça feira) e dia 26/01/2017 (quinta feira) da Jazida do DER/DF localizada na DF-435, km 01, próxima ao entroncamento com a DF-445 - Ceilândia/DF. A Figura 6 é uma imagem retirada do Google Earth mostrando o local da Jazida, cujas coordenadas geográficas são: latitude 1542'16"S e longitude $48^{\circ} 10^{\prime} 4^{\prime \prime O}$. A escolha do solo foi feita com base em estudos já realizados por outros pesquisadores e pela utilização dele em projetos de infraestrutura no Distrito Federal.

Figura 6 - Localização do local de retirada da amostra deformada de solo

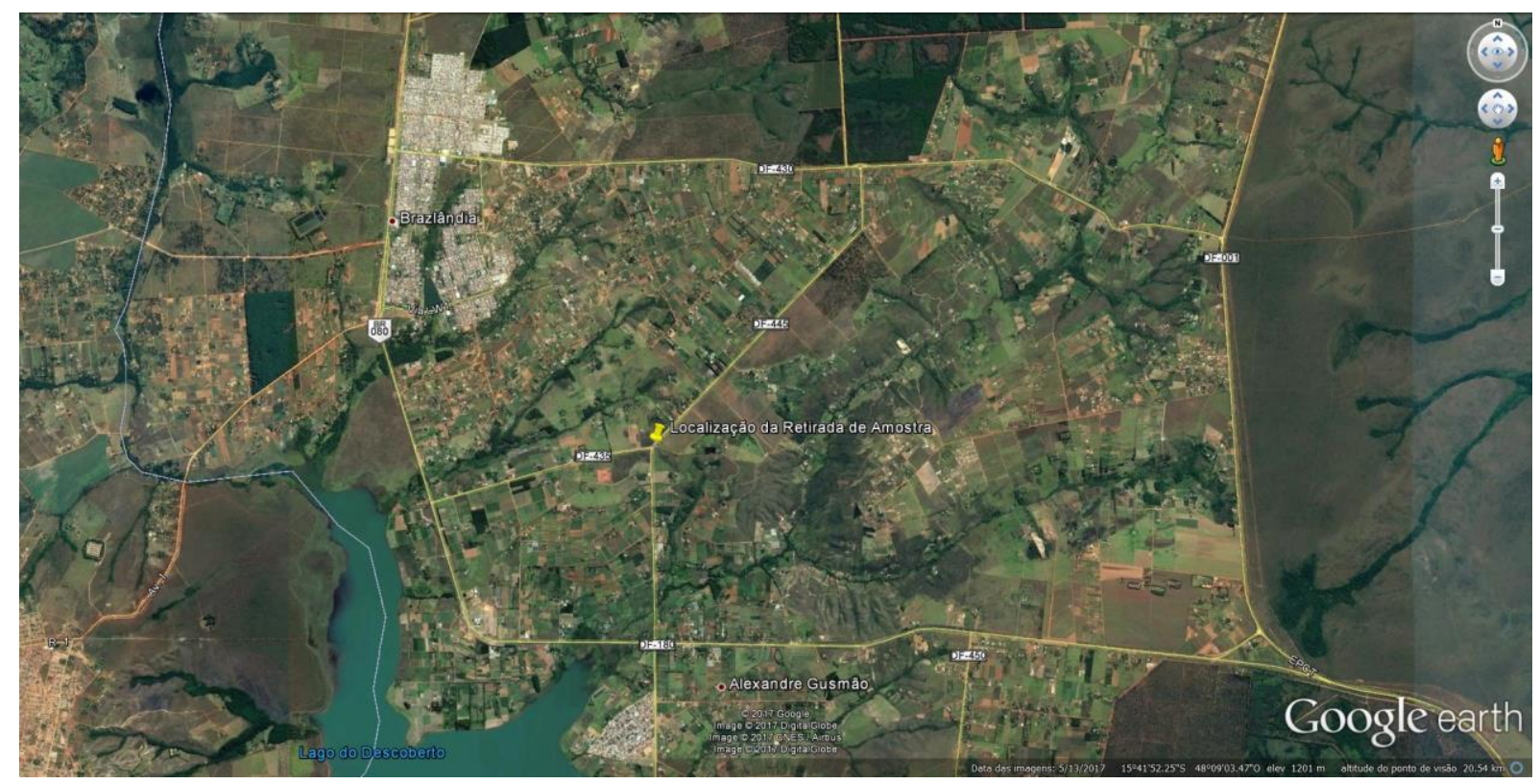

Fonte: Google Earth 
$\mathrm{Na}$ coleta foram retirados amostras indeformadas conforme norma ABNT NBR 9604/86 em torno de $800 \mathrm{~kg}$ de materiais (solos) para os dias realizados. Logo após, a amostra foi levada ao laboratório, localizado no bloco 11 do UniCEUB, campus Asa Norte, para a preparação desse solo destinada aos ensaios de compactação e caracterização de amostra de acordo com a norma ABNT NBR 6457/86. Os ensaios de caracterização do solo foram realizados nesse mesmo laboratório, enquanto os ensaios de compactação foram executados no campus de Taguatinga do UniCEUB. A Figura 7 mostra uma foto do local de retirada da amostra de solo.

Figura 7 - Retirada de amostra deformada de solo para aterro

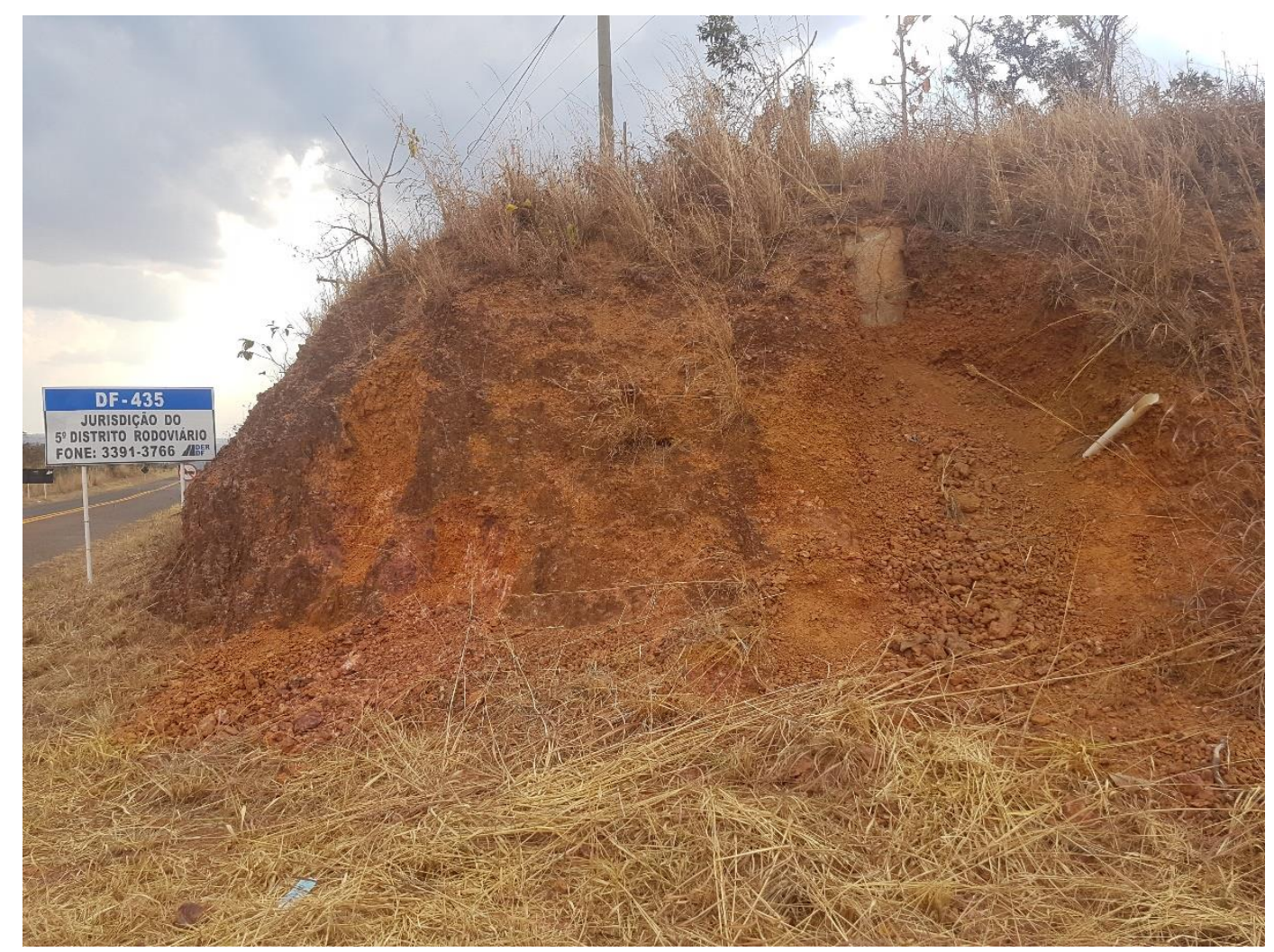

Fonte: Elaborada pelo autor

\subsubsection{Caracterização da Lignosulfonato}

Para a realização dessa pesquisa, utilizou-se um rejeito de celulose obtida da produção de papel localizada na cidade de Imperatriz-MA na Estrada do Arroz, Km $13+2 \mathrm{~km}$ à esquerda - Zona Rural - Santa Rita (Figura 8). 
Figura 8 - Localização da indústria da produção de papel e do rejeito utilizado.

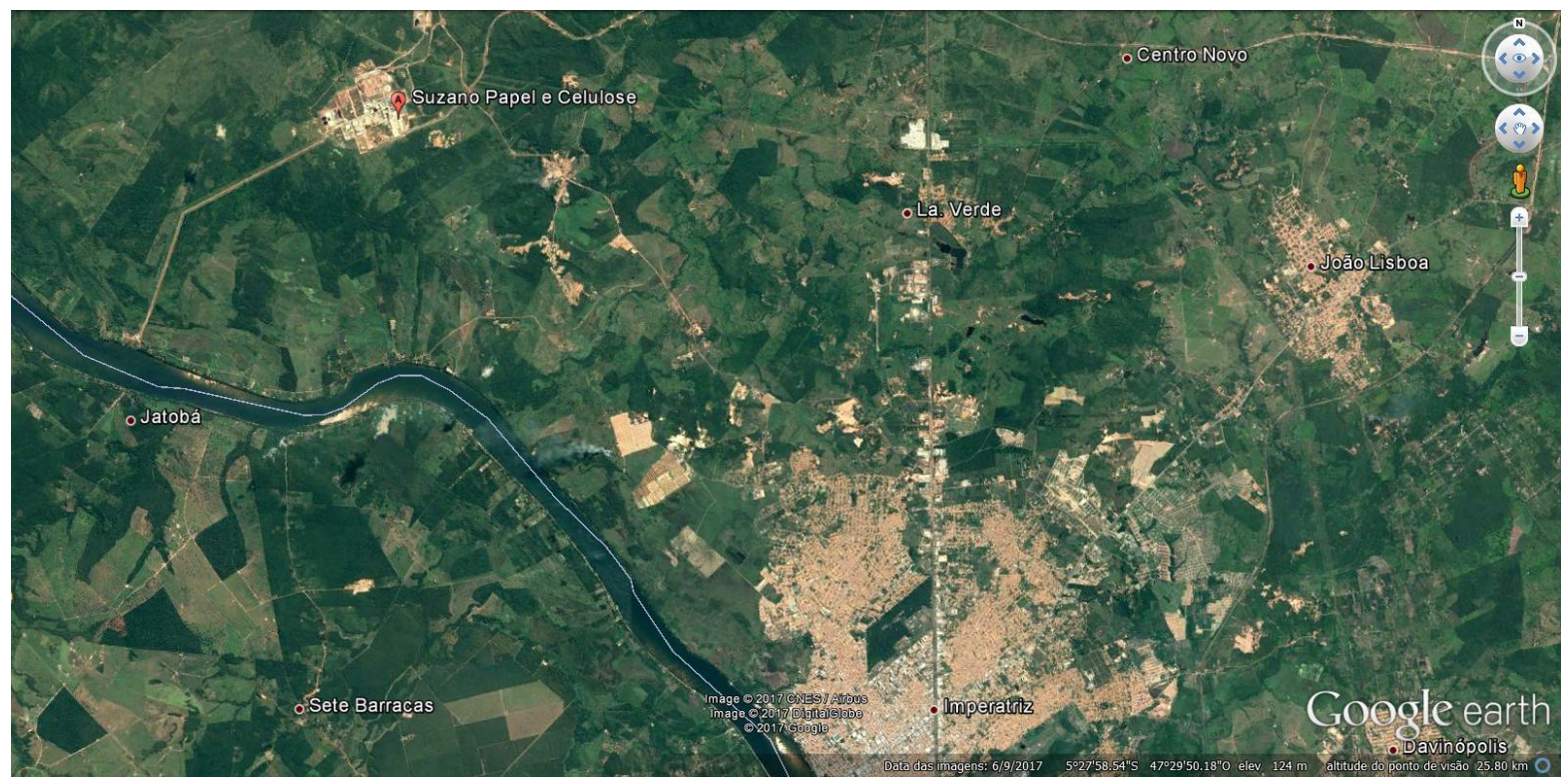

De forma a caracterizar o material utilizado nessa pesquisa foi obtido em laboratório à massa especifica e a granulometria do rejeito em estudo no laboratório do UniCEUB (Tabela 8) e a composição química no laboratório Soloquímica (Tabela).

Tabela 8 - Valores de massa específica.

Observando-se que os valores encontrados no ensaio para a massa específica apresentados na Tabela 8 apresentaram uma densidade média de $X X, X$ kgf $/ \mathrm{cm}^{3}$ e uma classificação granulométrica do tipo.

Segundo as normas de utilização de material do tipo aglomerante em obras de infraestrutura (Departamento Nacional de Infraestrutura de Transporte - DNIT) propôs realizar misturas de solo com lignosulfonato nas proporções de 2\%, 4\%, $6 \%$ e $8 \%$ tentando verificar seu desempenho na classificação de solo melhorado com lignosulfonato de $2 \%$ e $4 \%$ (DNIT 140 - ES, 2010) e solo-lignosulfonato de 6\% e $8 \%$ (DNIT 143 - ES, 2010)

\subsection{Metodologia de Ensaios}

Subsequente a retirada de solo da Jazida do DER/DF, as amostras deformadas foram encaminhadas para o laboratório de geotecnia, localizado no bloco 11 do UniCEUB, no campus da Asa Norte. Foram coletados em torno de $800 \mathrm{~kg}$ de solo para caracterização da amostra, compactação, resistência ao cisalhamento direto, 
adensamento e permeabilidade. Foi utilizado o solo passante pela peneira $4.8 \mathrm{~mm}$ conforme sugestão da norma ANBT NBR 6457/86 - Amostras de solo - Preparação para ensaios de compactação e ensaios de caracterização.

Desta forma a primeira etapa realizada foi à preparação do solo para os ensaios de caracterização, de acordo com a norma NBR 6457/86. O processo utilizado para preparação do solo foi com secagem prévia. A Figura 9 mostra uma amostra do solo sendo seca ao ar livre.

Figura 9 - Amostra do solo secando ao ar livre

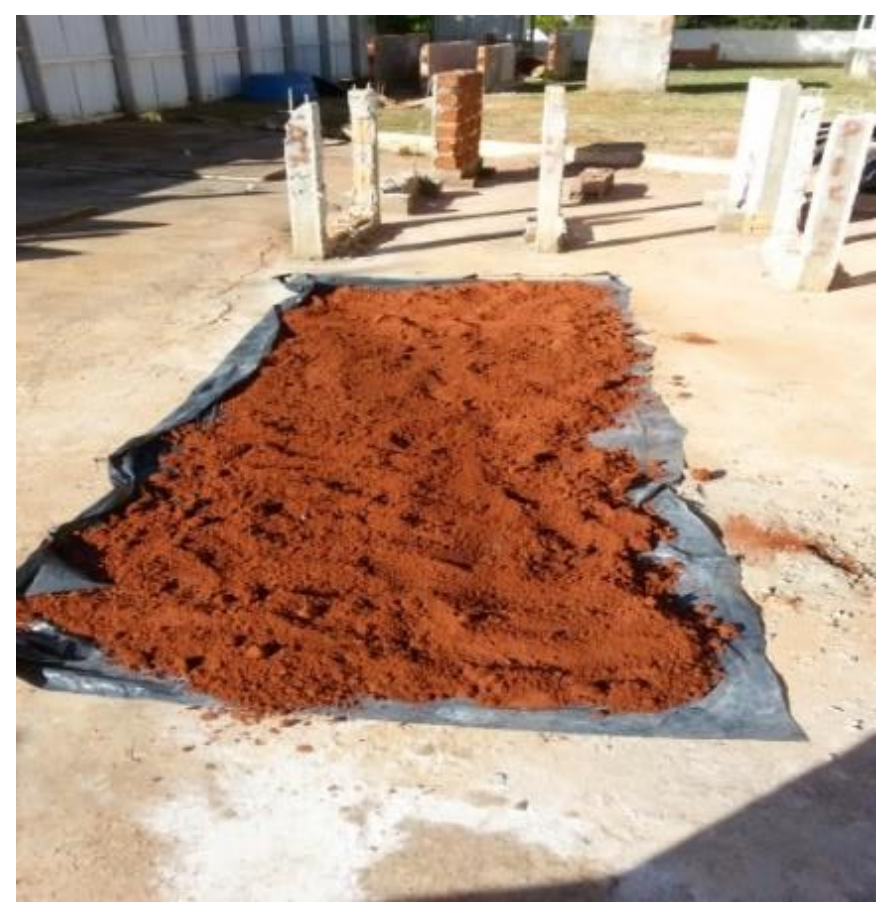

Fonte: Elaborada pelo autor

A Figura 10 apresenta a secagem da amostra ao ar livre conforme especificado em norma para o peneiramento com destorroamento (Figura 10) do material retido na peneira para o processo de caracterização e compactação dos experimentos. 
Figura 10 - Solo sendo destorroado

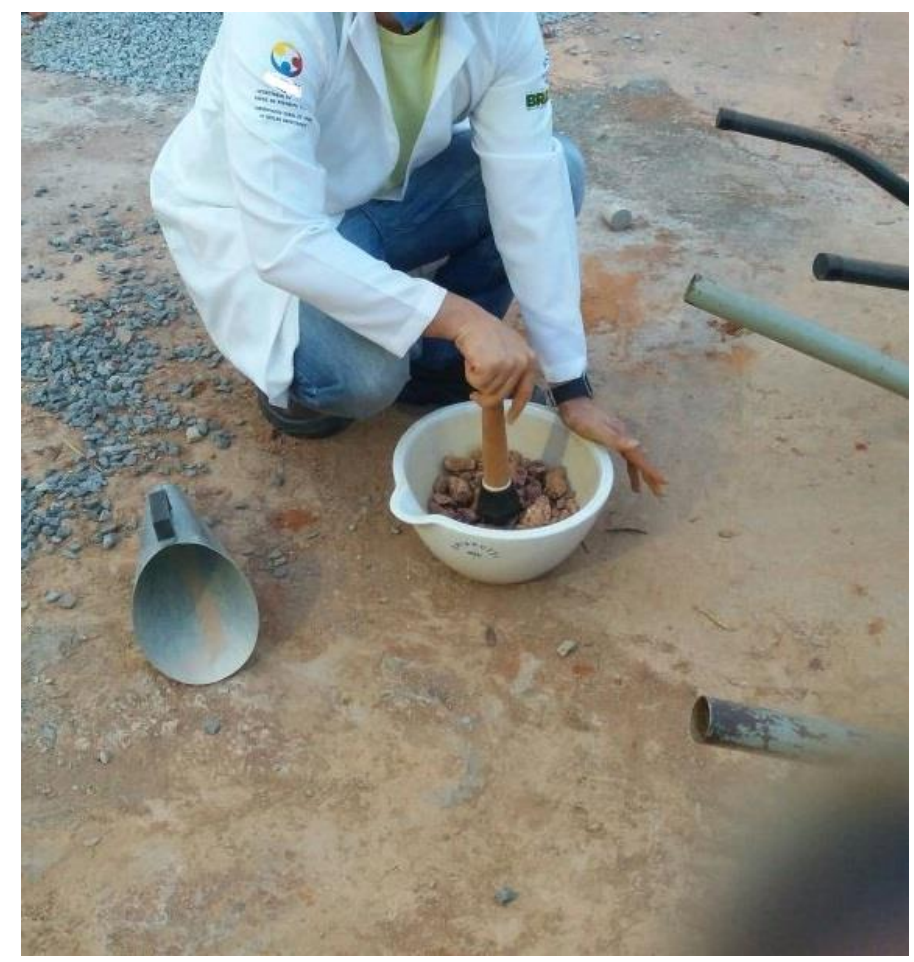

Fonte: Elaborada pelo autor

Seguidamente à preparação das amostras, efetuaram-se os ensaios de caracterização do solo, que foram constituídos pela Análise Granulométrica, Limites de Atterberg e MCT. Os ensaios são detalhados em breve.

\subsubsection{Análise Granulométrica}

Antes da preparação do solo para a compactação, um dos ensaios os quais o solo é submetido para sua identificação, é a análise granulométrica que vai definir o tamanho, a quantidade e a distribuição dos grãos que o constituem. Ao final dessa análise gera-se uma curva de distribuição granulométrica, que apresenta como finalidade a classificação. A quantidade de amostra a ser utilizada nesse ensaio é definida conforme a norma NBR 6457/86. Também é demonstrada de acordo com a Tabela 9. 
Tabela 9 - Quantidade de amostra para análise granulométrica

\begin{tabular}{c|c}
\hline $\begin{array}{c}\text { Dimensões dos grãos maiores contidos na } \\
\text { amostra, determinada por observação } \\
\text { visual (mm) }\end{array}$ & $\begin{array}{c}\text { Quantidade mínima a tomar } \\
(\mathrm{kg})\end{array}$ \\
\hline$<5$ & 1 \\
\hline 5 a 25 & 4 \\
\hline$>25$ & 8 \\
\hline
\end{tabular}

Fonte: NBR 6457/86

Desta forma após o cumprimento com o que foi sugerido pela NBR 6457/86 quanto à observação visual das dimensões dos grãos, foram selecionados $4 \mathrm{~kg}$ para amostragem para análise granulométrica.

A realização da análise granulométrica foi feita de acordo com as determinações da norma ABNT NBR 7181/84 - Solo - Análise Granulométrica. O ensaio é composto por três etapas: peneiramento grosso, sedimentação e peneiramento fino.

\subsubsection{Peneiramento grosso}

A NBR 7181/84 determina a capacidade nominal da balança (Tabela 10) a ser utilizada para a medição das frações retidas nas peneiras.

Tabela 10 - Balança a ser utilizada na Análise Granulométrica

\begin{tabular}{c|c|c}
\hline Dimensão dos grãos maiores & \multicolumn{2}{|c}{ Balança a ser utilizada } \\
\cline { 2 - 3 } contidos na amostra $(\mathrm{mm})$ & Capacidade nominal $(\mathrm{kg})$ & Resolução $(\mathrm{g})$ \\
\hline$>25$ & 10 & 1 \\
\hline 5 a 25 & 5 & 0,5 \\
\hline$<5$ & 1,5 & 0,1 \\
\hline
\end{tabular}

Fonte: NBR 7181/84

Segundo a Tabela 10 utilizou-se uma balança com capacidade nominal de $5 \mathrm{~kg} \mathrm{e}$ resolução de $0,5 \mathrm{~g}$. A Figura 11 mostra as peneiras utilizadas no peneiramento grosso. 
Figura 11 - Peneiras para granulometria grossa

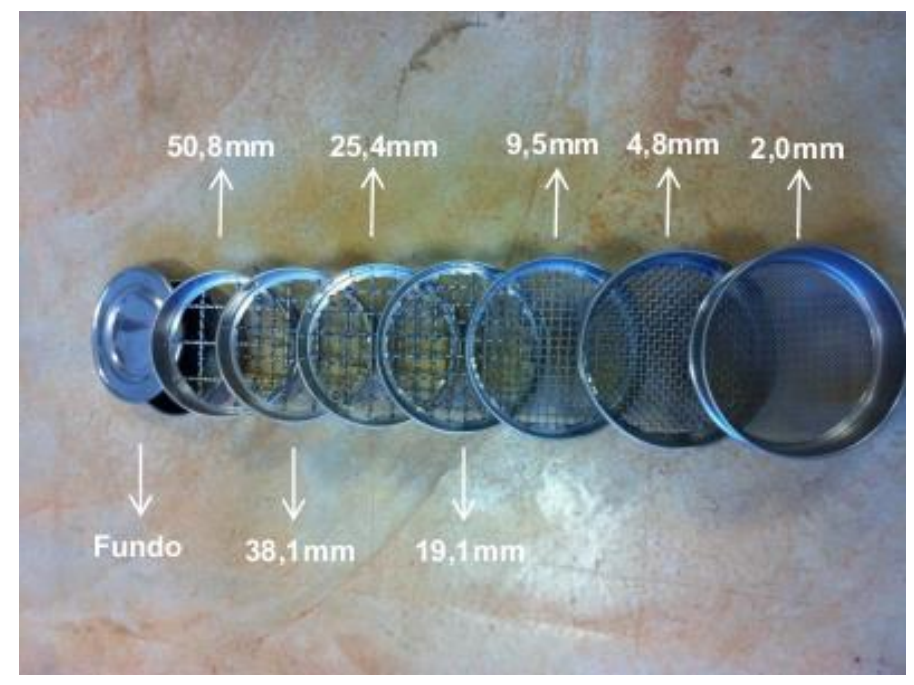

Fonte: (SOUSA, 2013)

\subsubsection{Sedimentação}

O ensaio de sedimentação foi realizado em duas etapas: a primeira com defloculante, aplicando o hexametafosfato de sódio em uma solução de $125 \mathrm{ml}$, com a concentração de $45,7 \mathrm{~g}$ de sal por $1000 \mathrm{ml}$ de solução e a segunda sem defloculante, apenas com a adição de água destilada. As duas amostras ficaram em repouso por aproximadamente 12 horas para que o defloculante pudesse agir desintegrando as partículas do solo. Equipamentos utilizados na sedimentação são mostrados na Figura 12. 
Figura 12 - Equipamentos utilizados no ensaio de sedimentação

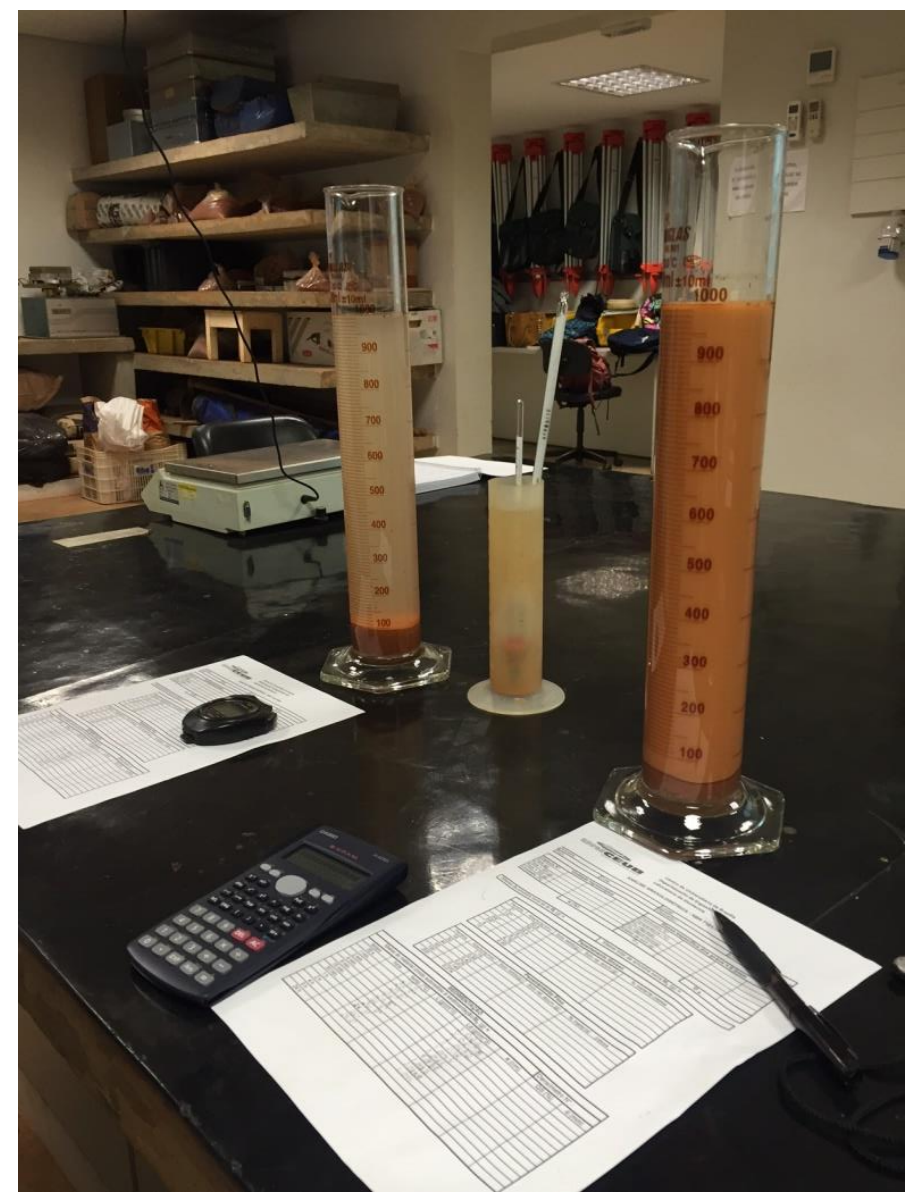

Fonte: Elaborada pelo autor

\subsubsection{Peneiramento Fino}

Após 24 horas do início da sedimentação fez-se a última leitura do decímetro, o material presente na proveta foi despejado na peneira $0,075 \mathrm{~mm}$, lavando-o com água potável e levado para a estufa de acordo com a NBR 7181/84. Após o solo atingir a constância de massa, utilizou-se o agitador mecânico, por um período de 5 minutos, para a realização do peneiramento fino, passando a amostra nas peneiras de $1,2 \mathrm{~mm}, 0,6 \mathrm{~mm}, 0,42 \mathrm{~mm}, 0,25 \mathrm{~mm}, 0,15 \mathrm{~mm}$ e $0,075 \mathrm{~mm}$, conforme mostra a Figura 13. 
Figura 13 - Peneiras no agitador mecânico

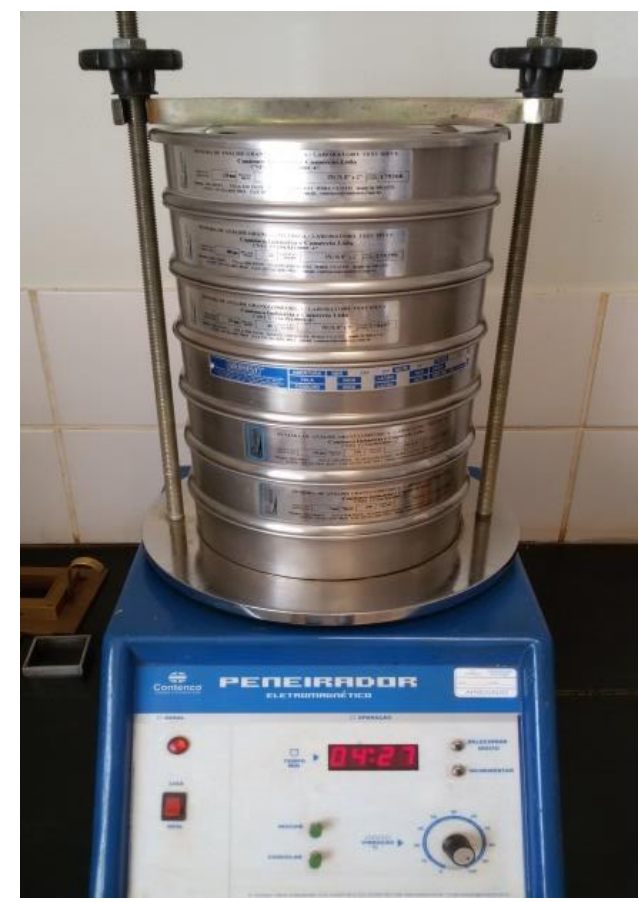

Fonte: Elaborada pelo autor

\subsubsection{Massa Específica Real dos Grãos}

Para a execução do ensaio foi utilizado $500 \mathrm{~g}$ do material passante na peneira de 4,8 mm para a determinação da massa específica dos grãos, conforme a norma ABNT NBR 6508/84 - Grãos de solos que passam na peneira de 4,8 mm Determinação da Massa Específica. O método utilizado foi o com secagem prévia. Ao final do ensaio utilizou-se a massa específica da água, em $\mathrm{g} / \mathrm{cm}^{3}$, num intervalo de temperatura entre $0^{\circ} \mathrm{C}$ e $40^{\circ} \mathrm{C}$, encontrado em anexo à norma NBR 6508/84, para encontrar os valores da massa específica da água para a temperatura de cada picnômetro medido no ensaio. A Figura 14 mostra os picnômetros na bomba de vácuo, conforme rege o item 4.8 da NBR 6508/84. 
Figura 14 - Amostras na bomba de vácuo

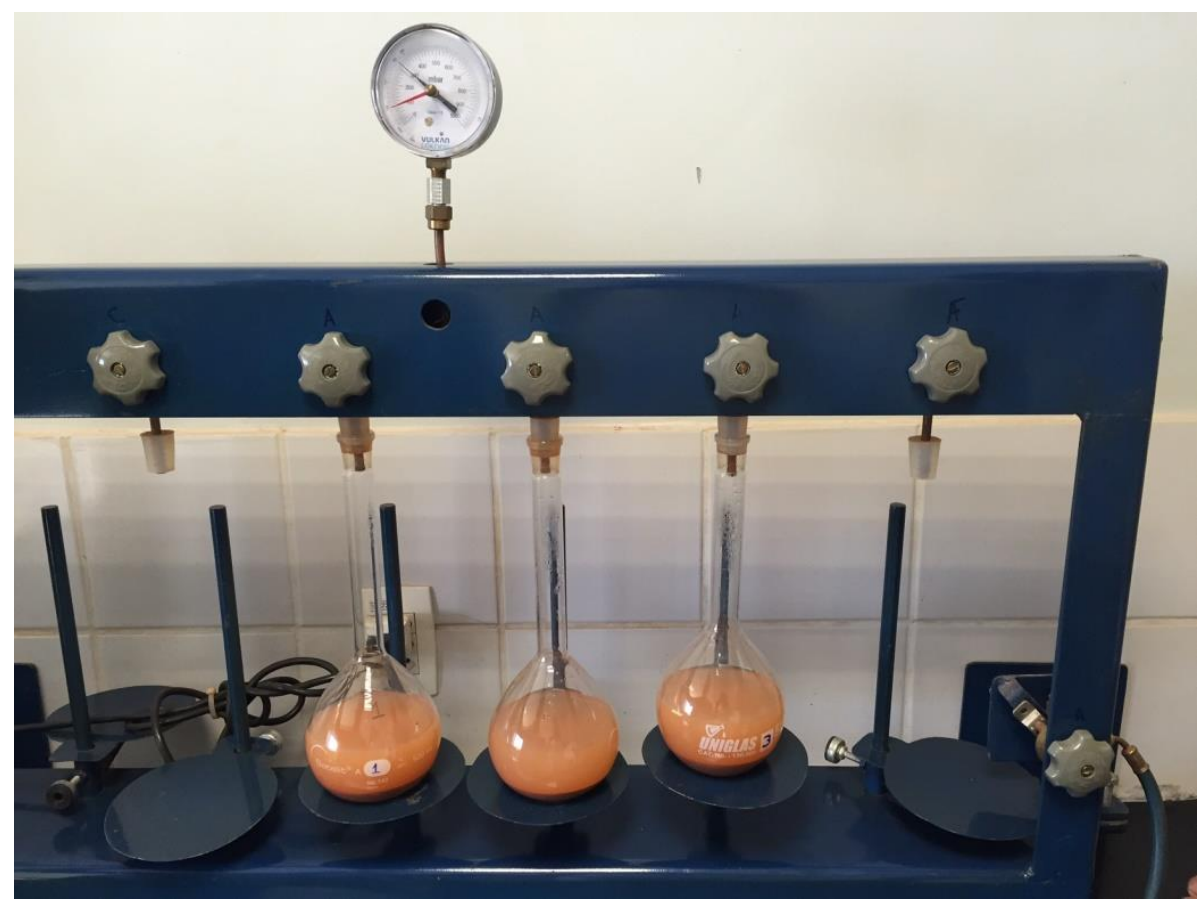

Fonte: Elaborada pelo autor

\subsubsection{Limites de Atterberg}

Para a realização dos ensaios de Limite de Atterberg (Limite de plasticidade e limite de liquidez) foi separado $200 \mathrm{~g}$ de solo, passante na peneira $0,42 \mathrm{~mm}$ conforme estabelecido pela norma NBR 6457/86. Na qual a metodologia de execução de ambos ensaios e mostrado a seguir:

\subsubsection{Limite de Liquidez}

O ensaio de limite de liquidez foi realizado conforme a norma ABNT NBR 6459/84 Solo - Determinação do Limite de Liquidez, na qual, utilizou-se o método com secagem prévia. A Figura 15 mostra a realização do limite de liquidez com 0 aparelho de Casagrande. 
Figura 15 - Aparelho de Casagrande

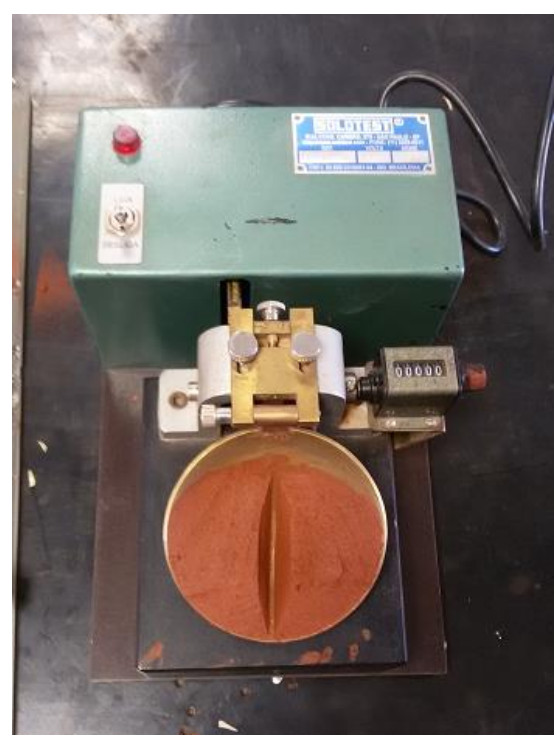

Fonte: Elaborada pelo autor

\subsubsection{Limite de Plasticidade}

$\mathrm{Na}$ realização do ensaio de limite de plasticidade houve a separação de três amostras para execução do ensaio, conforme a norma ABNT NBR 7180/84 - Solo Determinação do Limite de Plasticidade. $\mathrm{Na}$ qual foram realizados procedimentos segundo a norma ABNT NBR 6457/86 com secagem previa. De acordo com os procedimentos estabelecidos pela norma, foram moldados os solos com consistência de pasta sobre a placa de vidro de forma a obter corpos cilíndricos de aproximadamente $3 \mathrm{~mm}$ de diâmetro e $10 \mathrm{~mm}$ de altura (Figura 16), de acordo com o item 4.2.5 da NBR 7180/84.

Figura 16 - Cilindro de solo ensaiado para o Limite de Plasticidade

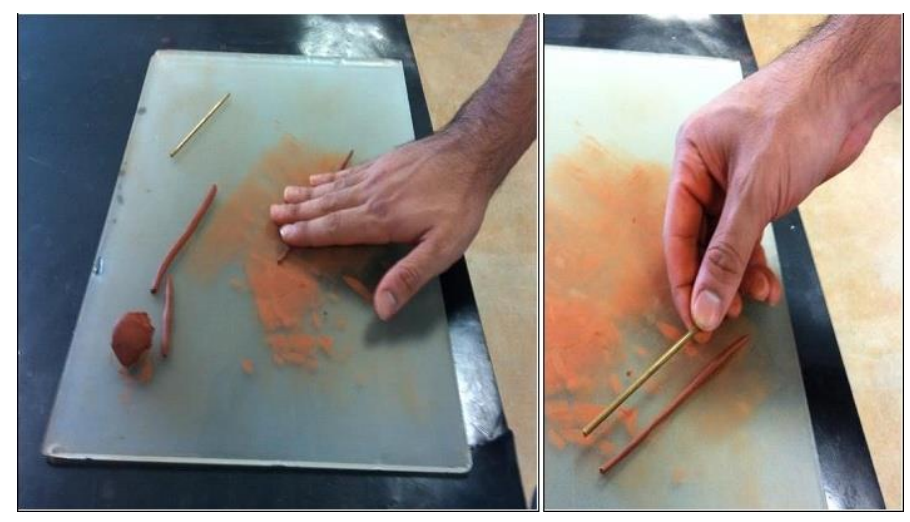

Fonte: (Cunha, 2014) 
Ao final dos experimentos, utiliza-se a média das umidades encontradas nos ensaios de Limite de Plasticidade (LP) e no Limite de Liquidez (LL) para obter o Índice de Plasticidade (IP).

\subsubsection{Identificação e Descrição Expedita de solos, metodologia MCT}

Sendo o Brasil um país de clima majoritariamente tropical, a metodologia MCT é imprescindível para a identificação e classificação do solo, pois atende as peculiaridades do material no que se diz respeito à laterização do solo. $\mathrm{Na}$ realização do ensaio, a metodologia foi executada de acordo com o método das pastilhas para identificação expedita, apresentado por Nogami e Villibor (1980).

Inicialmente foi reservada uma fração de $100 \mathrm{~g}$ de solo passante na peneira de 0,42 $\mathrm{mm}$ e foi disposto sobre a face fosca da placa de vidro. Logo após foi adicionada água destilada e deu-se começo no procedimento de espatulação do solo até obter uma consistência de pasta de forma a dar inicio ao ensaio de penetração com uso de um mini-penetrômetro na pasta até atingir uma penetração de $1 \mathrm{~mm}$.

Em seguida, moldaram-se três bolinhas com a pasta obtida anteriormente a fim de coloca-las no interior dos anéis, exercendo a pressão necessária para que o anel fosse totalmente preenchido, retirado o excesso de forma que as duas faces de cada bolinha ficassem preenchidas pela pasta de solo. Depois de preenchido os anéis, foram moldadas e pesadas outras três bolinhas com peso aproximado de $10 \mathrm{~g}$ cada. Os anéis preenchidos foram colocados em posição vertical e juntamente como as bolinhas ficaram secando ao ar por 12 horas.

Após secas, as bolinhas foram pesadas novamente para determinação da umidade e submetidas a testes de esmagamento a fim de determinar a resistência ao esmagamento. Utilizando o paquímetro digital, foram medidos os diâmetros dos anéis e de suas respectivas pastilhas, obtendo assim a contração das pastilhas de solo que estavam presentes no interior dos anéis. A Figura 17 mostra o paquímetro e os anéis com o solo. 
Figura 17 - Paquímetro digital

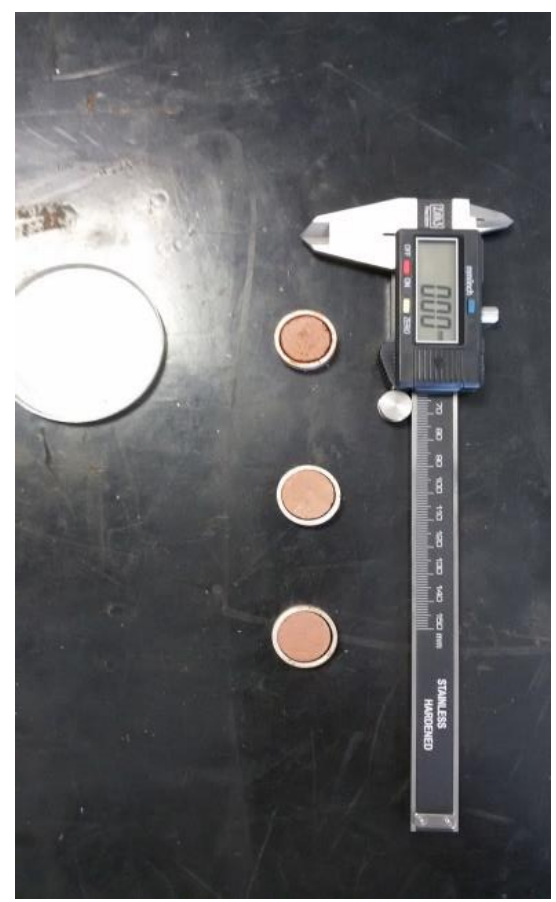

Fonte: Elaborada pelo autor

As pastilhas foram colocadas sobre uma placa porosa saturada e recoberta com papel filtro e em seguida foi observado o tempo necessário para completa reabsorção d' água, conforme demonstra a Figura 18.

Figura 18 - Pastilhas submetidas à reabsorção d'água

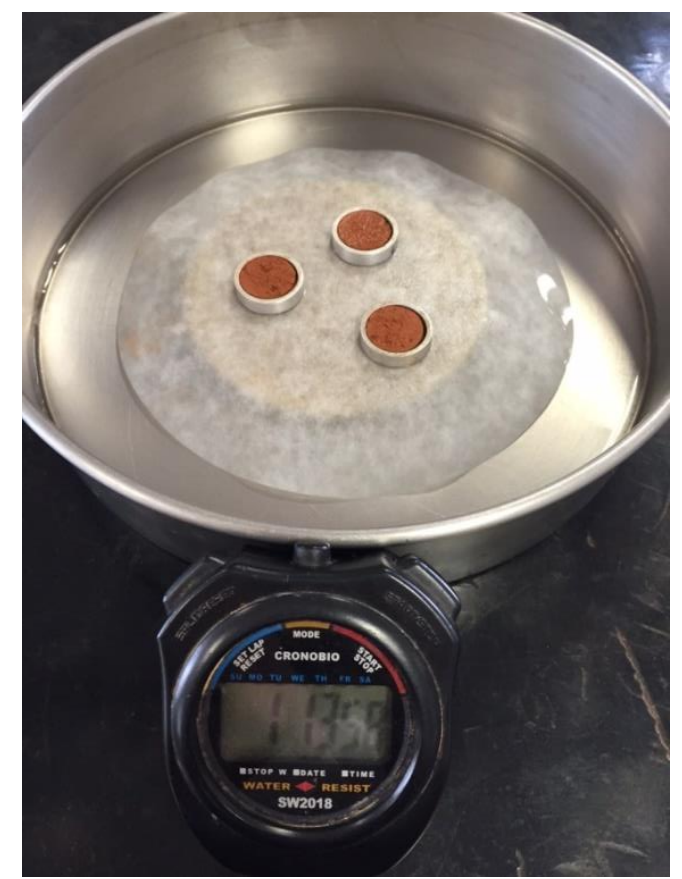

Fonte: Elaborada pelo autor 
Com o auxílio do mini-penetrômetro foi metida a penetração em cada pastilha, como mostra a Figura 19.

Figura 19 - Determinação da penetração nas pastilhas de solo depois de umedecidas

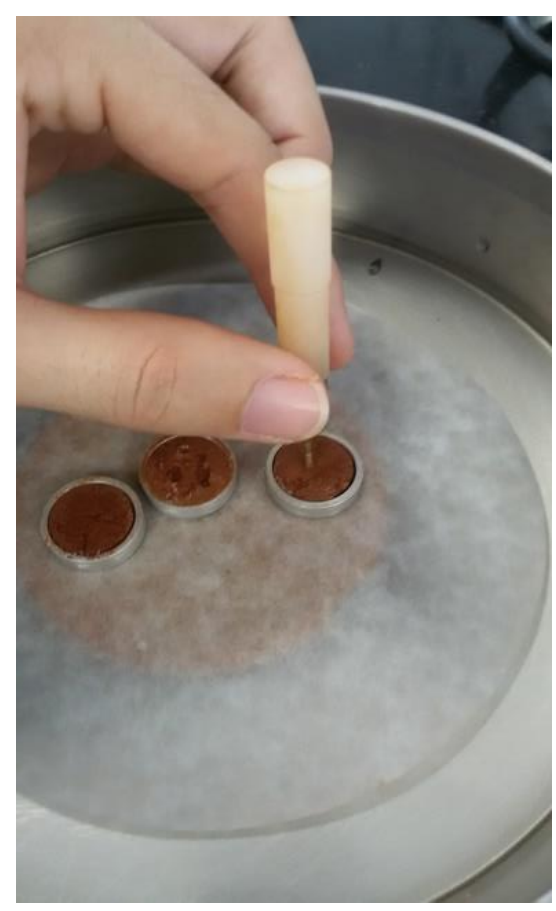

Fonte: Elaborada pelo autor

\subsubsection{Massa específica da Lignosulfonato}

Após os ensaios de caracterização do solo realizou-se um experimento para definir a massa específica do Lignosulfonato utilizado nessa pesquisa de forma a obter algum parâmetro do material. No procedimento executado, separou-se uma quantidade de amostra de Lignosulfonato de forma a preencher um cilindro com dimensões de $12,07 \mathrm{~cm}$ de diâmetro, 17,68 cm de altura e peso de 2,204 kg. O cilindro empregado nesse experimento é o mesmo utilizado no ensaio de frasco de areia ABNT NBR 7185/86 - Solo - Determinação da massa específica aparente "in situ", com emprego do frasco de areia. O preenchimento da Lignosulfonato no cilindro foi realizado sem emprego de nenhuma energia de compactação. A Figura 20 mostra o momento de medição do peso do cilindro com a Lignosulfonato. 
Figura 20 - Medição do peso do molde de cilindro mais Lignosulfonato

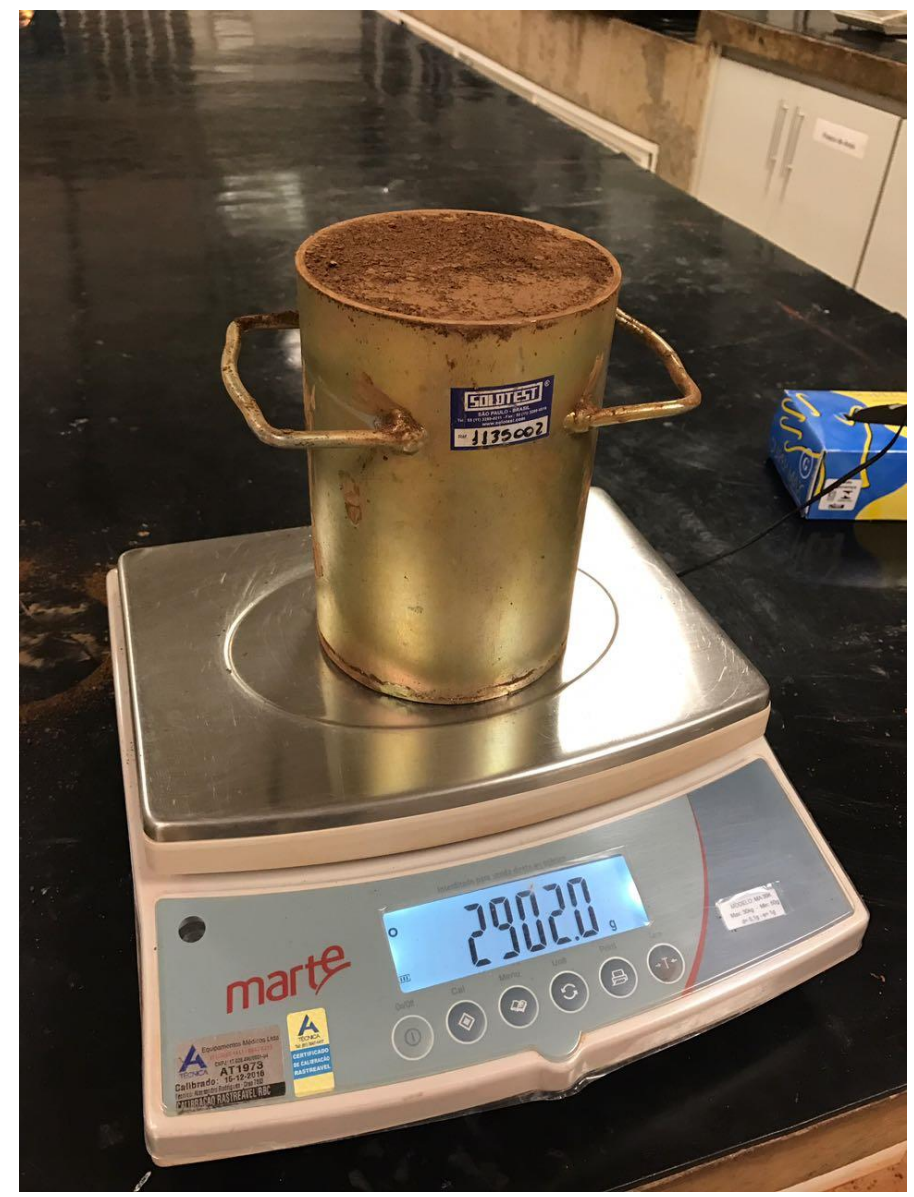

Fonte: Elaborada pelo autor

\subsubsection{Compactação}

Os procedimentos de ensaio de compactação, expansão e penetração foram executados nos laboratórios do Campus Asa Norte e no Campus de Taguatinga do UniCEUB. O ensaio de compactação tem como intuito alcançar os parâmetros de umidade ótima é a massa especifica máxima seca de solos quando compactado, de acordo com a norma ABNT NBR 7182/86 - Solo - Ensaio de compactação. Para execução dos ensaios foram realizados procedimentos de preparação de amostra para compactação conforme ABNT NBR 6457/86 como já apresentado anteriormente. Sendo utilizado o material passante na peneira de $4,8 \mathrm{~mm}$, desprezando o material retido.

O ensaio de compactação foi realizado com base na norma ABNT NBR 7182/86, que visa determinar a relação entre a umidade ( $w \%$ e o peso específico seco do solo $\left(Y_{d}\right)$ quando compactado. O método utilizado foi o do ensaio realizado sem reuso de 
material, sobre amostras preparadas com secagem prévia até a umidade higroscópica. Devido às características do solo, usou-se o cilindro grande.

Com o objetivo de se comparar o comportamento do solo quando associado a Lignosulfonato, o ensaio de compactação foi realizado cinco vezes, cada uma com características diferentes. Na primeira vez utilizou-se apenas o solo, com o objetivo de se criar parâmetros de comparação para os demais ensaios. A energia utilizada foi a Intermediária (26 golpes por camada), por ser a energia utilizada para camadas de barragens. Os outros quatro ensaios foram realizados conforme ilustrado a seguir:

- Solo melhorado com Lignosulfonato - $2 \%$ de adição;

- Solo melhorado com Lignosulfonato - $4 \%$ de adição;

- Solo-Lignosulfonato - com $6 \%$ de mistura;

- Solo-Lignosulfonato - com $8 \%$ de mistura;

Com a finalidade de se obter maiores parâmetros de resistência e custo de execução intermediário se comparado com a energia normal e modificada foi tomada a decisão de utilizar a energia Intermediária nos ensaios.

A Figura 21 apresenta um corpo de prova após ser desmoldado e ilustra a homogeneidade do corpo de prova com adição do Lignosulfonato. Ressalta que visualmente não houve diferença entre as soluções de melhoramento e mistura com Lignosulfonato. 
Figura 21 - Corpo de prova desmoldado com adição de $2 \%$ de Lignosulfonato.

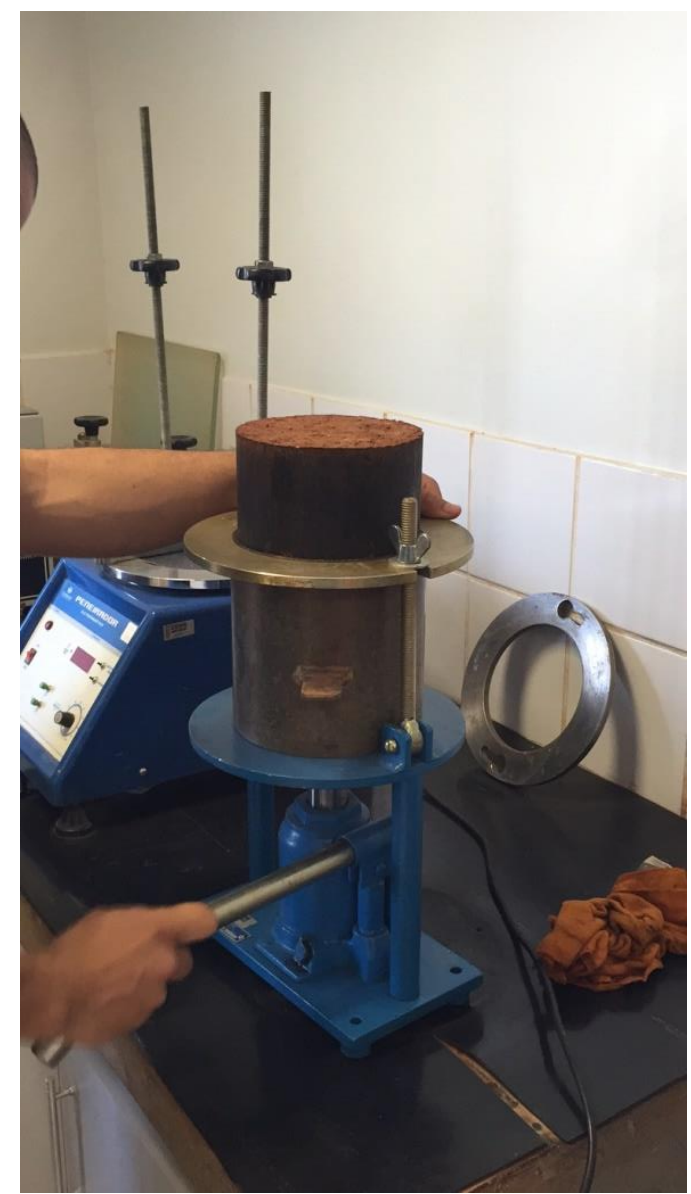

Fonte: Elaborada pelo autor

\subsubsection{Expansão}

O ensaio de expansão foi realizado de acordo com a norma ABNT NBR 9895/87 Solo - Índice de Suporte Califórnia, com os corpos de prova obtidos nos ensaios de compactação para todos os pontos de umidade.

Nesse ensaio, os corpos de prova foram instrumentados com extensômetros com precisão de 0,01 $\mathrm{mm}$ e imersos em um reservatório de água, localizada no laboratório, por um período de quatro dias, valor mínimo exigido pela NBR 9895/87. As leituras no extensômetro foram realizadas de 24 em 24 horas. A Figura 22 mostra os corpos de prova durante o ensaio de expansão. 
Figura 22 - Corpos de prova imersos em água

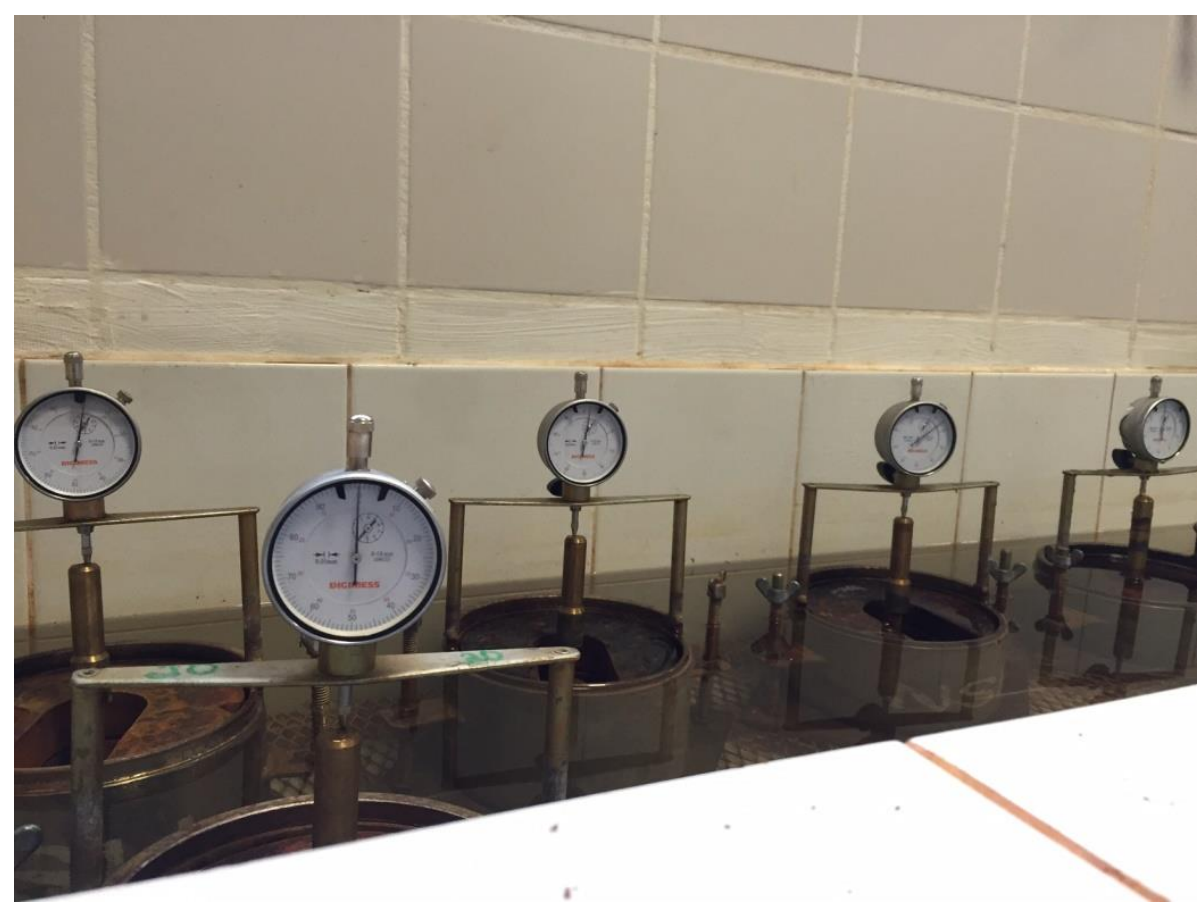

\subsubsection{Penetração}

Para o ensaio de penetração foi realizado de acordo com a norma NBR 9895/87, com os corpos de prova obtidos nos ensaios de compactação após a expansão. $O$ objetivo desse ensaio foi encontrar os valores das pressões na penetração de 2,54 mm e 5,08 mm de um cilindro padrão (Índice de Suporte Califórnia - ISC) dos corpos de prova para todas as umidades compactadas, e verificar o influência da incorporação do Lignosulfonato nos valores encontrados. A Figura 23 mostra a prensa no momento do ensaio de penetração. 
Figura 23 - Ensaio de penetração em andamento

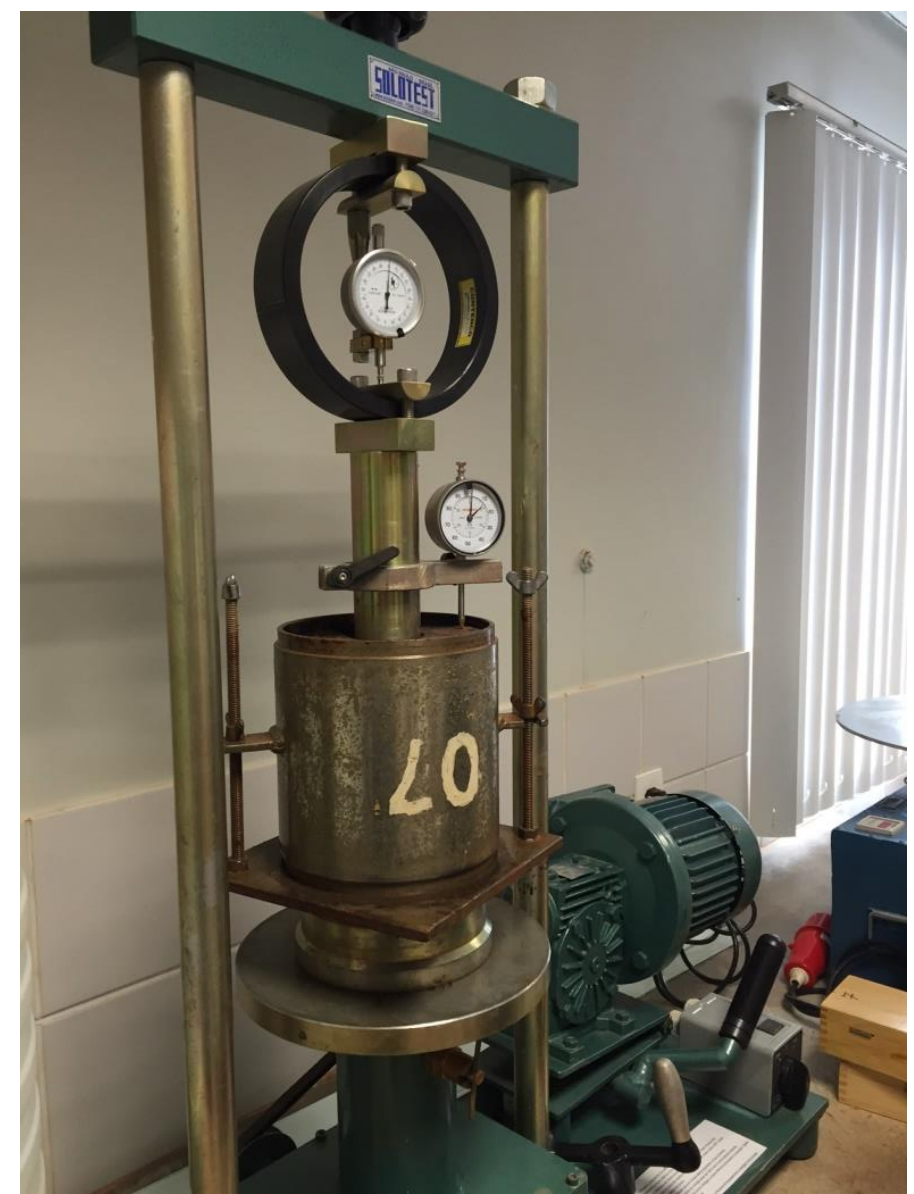

Fonte: Elaborada pelo autor

\subsubsection{Cisalhamento direto}

Considerando que não existe norma brasileira que regulamente as condições e práticas a serem seguidas para execução do ensaio de cisalhamento direto, foi tomada como referência a norma American Society for Testing and Materials ASTM D3080 (ASTM, 2004) para a determinação de procedimentos de ensaio, equipamentos e dimensões convencionais, aplicáveis a ensaios de cisalhamento direto considerados "padrão". A Figura 24 permite visualizar o equipamento em os procedimentos anteriormente citados. 


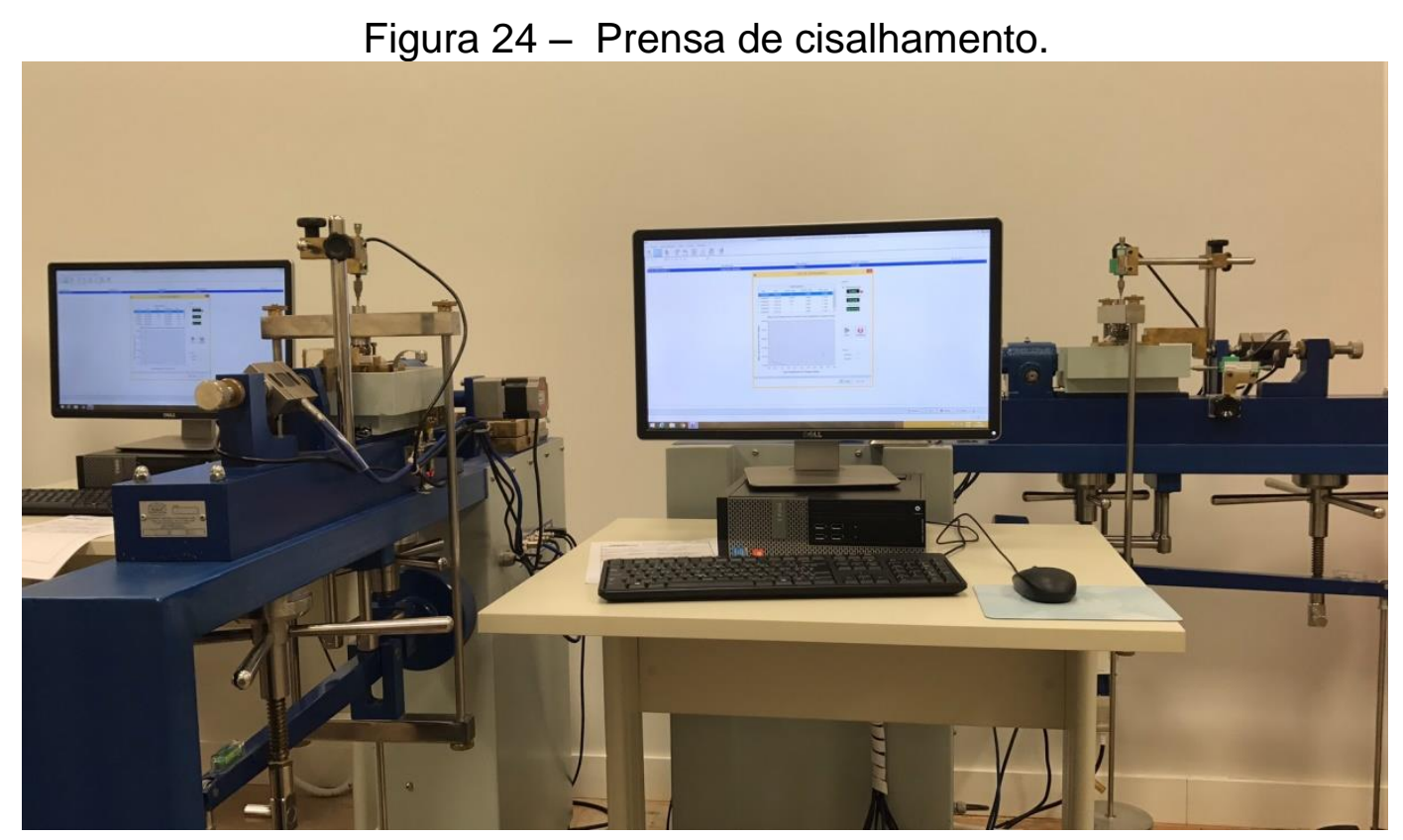

Fonte: Elaborada pelo autor

A norma ASTM D3080 (ASTM, 2004) apresenta mais de uma forma de se "moldar" o corpo de prova dependendo se esta trabalhando com amostra indeformada ou corpo de prova reconstituído.

Quando se trabalha com amostras deformadas de solo, os corpos de prova podem ser reconstituídos ou compactados. Em ambos os casos o material deve ser homogeneizado e separado nas quantidades necessárias para cada corpo de prova. Uma mistura de material e água deve ser feita em quantidades predefinidas para que se obtenha um corpo de prova com densidade e umidade geralmente definidos de forma a representar condições de campo, assim como as tensões normais de ensaio. Corpos de prova compactados conforme já apresentado anteriormente para o processo de compactação do material segundo os procedimentos preconizados pelas normas ABNT NBR 6457/1986 e ABNT NBR 7182/1986 (Proctor Intermediário), utilizados para determinar curvas de umidade ótima e densidade máxima. Foram avaliados todos os pontos de umidade e solução (mistura) de forma a utilizar os corpos de prova com maior resultante da compactação.

As cargas aplicadas para o ensaio de cisalhamento direto foram em função da simulação de barragens proposta nesta pesquisa ficando em função da geometria no caso sua altura de $50 \mathrm{~m}$ com peso específico máximo obtido nos ensaios de 
compactação. Assim as cargas normais aplicadas no ensaio $200 \mathrm{kPa}, 500 \mathrm{kPa}$ e $1000 \mathrm{kPa}$. 


\section{APRESENTAÇÃO E ANÁLISE DOS RESULTADOS}

Neste capítulo serão apresentados e analisados os resultados dos ensaios expostos na metodologia. Esta análise pretende observar o comportamento da associação da compactação do solo natural-Lignosulfonato nas proporções de $2 \%, 4 \%, 6 \%$ e $8 \%$ de Lignosulfonato e compará-lo com o comportamento do solo natural sem mistura. Além disso, verificará se os requisitos técnicos obtidos nos experimentos laboratoriais exigidos para análise da estabilidade para construção de aterros de barragens atendem.

\subsection{ANÁLISE GRANULOMÉTRICA}

De acordo com a metodologia descrita neste trabalho, a análise granulométrica foi obtida em laboratório através da execução do peneiramento grosso, da sedimentação com e sem defloculante e o peneiramento fino. Os respectivos resultados estão apresentados a seguir.

A Tabela 11 e Tabela 12 apresentam a quantidade de solo retido nas peneiras utilizadas no peneiramento grosso e peneiramento fino respectivamente.

Tabela 11 - Material retido no peneiramento grosso

\begin{tabular}{c|c|c|c|c}
\hline \multicolumn{5}{c}{ Peneiramento Grosso } \\
\hline Peneira & Abertura $(\mathrm{mm})$ & Solo retido $(\mathrm{g})$ & Solo retido acumulado $(\mathrm{g})$ & $\%$ de material que passa \\
\hline $2 "$ & 50,8 & $\mathbf{0 , 0 0}$ & 0,00 & 100,0000 \\
\hline $11 / 2^{\prime \prime}$ & 38,1 & $\mathbf{0 , 0 0}$ & 0,00 & 100,0000 \\
\hline $1^{\prime \prime}$ & 25,4 & $\mathbf{0 , 0 0}$ & 0,00 & 100,0000 \\
\hline $3 / 4^{\prime \prime}$ & 19,1 & $\mathbf{1 2 0 , 0 2}$ & 120,02 & 97,5797 \\
\hline $3 / 8^{\prime \prime}$ & 9,5 & $\mathbf{4 5 5 , 7 3}$ & 575,75 & 88,3895 \\
\hline 4 & 4,76 & $\mathbf{5 2 2 , 7 6}$ & 1098,51 & 77,8476 \\
\hline 10 & 2,00 & $\mathbf{5 3 5 , 1 8}$ & 1633,69 & 67,0553 \\
\hline
\end{tabular}

Tabela 12 - Material retido no peneiramento fino

\begin{tabular}{c|c|c|c|c}
\hline \multicolumn{5}{c}{ Peneiramento Fino } \\
\hline Peneira & Abertura $(\mathrm{mm})$ & Solo retido $(\mathrm{g})$ & Solo retido acumulado $(\mathrm{g})$ & \% de material que passa \\
\hline 16 & 1,19 & $\mathbf{5 , 7 1}$ & 5,71 & 61,5 \\
\hline 30 & 0,59 & $\mathbf{9 , 3 7}$ & 15,08 & 52,4 \\
\hline 40 & 0,42 & $\mathbf{4 , 1 6}$ & 19,24 & 48,4 \\
\hline 60 & 0,25 & $\mathbf{7 , 3 8}$ & 26,62 & 41,2 \\
\hline 100 & 0,149 & $\mathbf{8 , 1 0}$ & 34,72 & 33,4 \\
\hline 200 & 0,074 & $\mathbf{6 , 4 9}$ & 41,21 & 27,1 \\
\hline
\end{tabular}


A Figura 25 representa as curvas granulométricas obtidas através dos ensaios de sedimentação, fazendo a comparação das características do solo com e sem a adição defloculante.

Figura 25 - Curvas granulométricas do solo com e sem defloculante

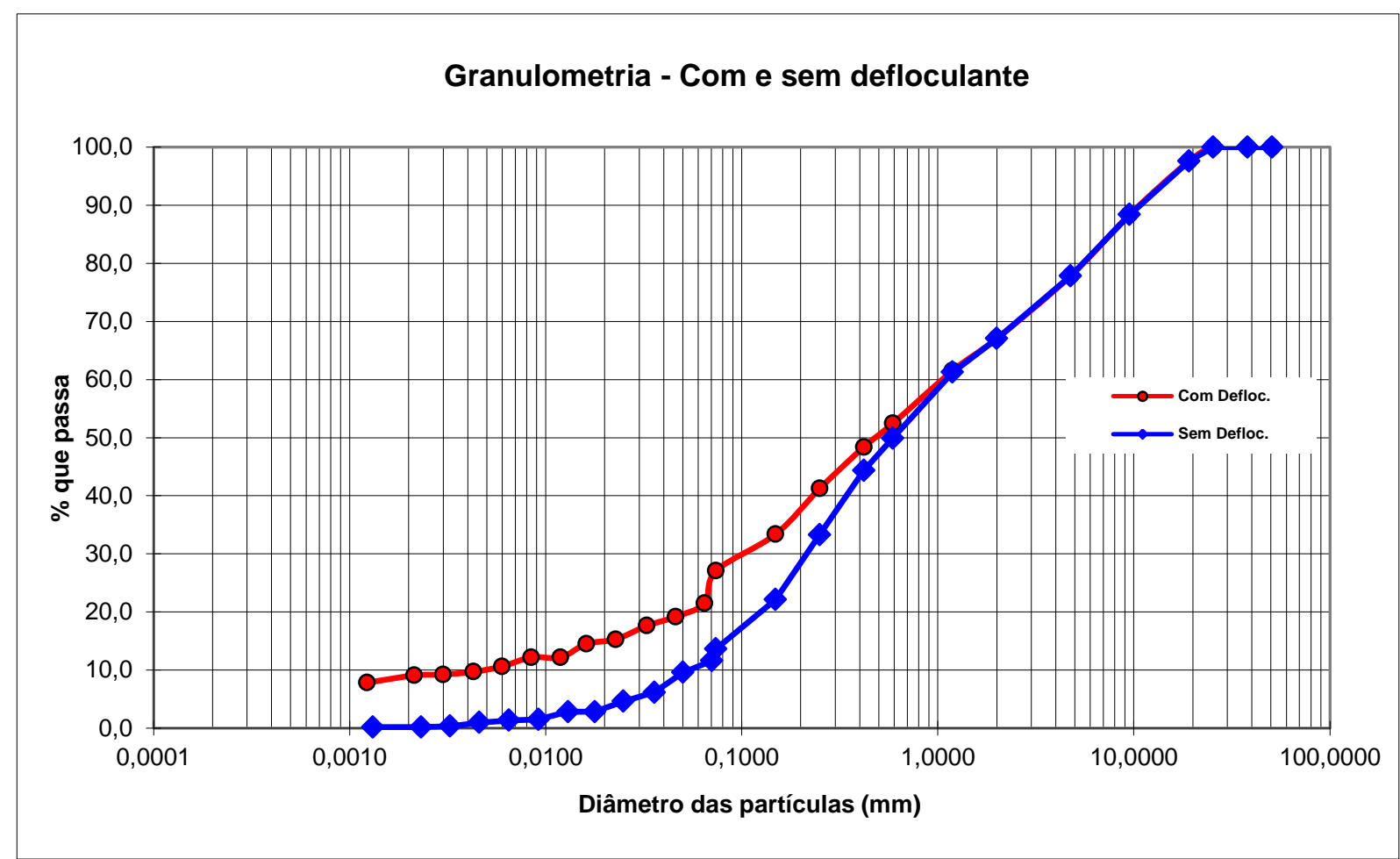

Analisando as curvas granulométricas com e sem defloculante obtidas, pode-se determinar a quantidade, em porcentagem, de grãos de cada diâmetro presente no material ensaiado. Observa-se que, segundo a curva granulométrica obtida no ensaio sem defloculante, o solo é composto por $32,9 \%$ de pedregulho, $56,5 \%$ de areia, $10,4 \%$ de silte e $0,2 \%$ de argila, sendo definido, com base na classificação da ABNT como solo areia siltosa. Porém, segundo a norma ABNT NBR 7181/84, o ensaio que classifica o solo é o ensaio com defloculante, sendo o ensaio sem defloculante apenas para fins comparativos.

Ao se realizar o ensaio com defloculante a porcentagem de pedregulho se manteve, mas, conforme o esperado, ocorreu uma desagregação das partículas arenosas em porções de silte e argila, sendo a última a que possuiu o maior aumento em porcentagem. Os resultados então mostraram que, além de $32,9 \%$ de pedregulho, o solo é composto por $46,2 \%$ de areia, $12,0 \%$ de silte e 8,9 de argila. Dessa forma, a classificação do solo se manteve como areia siltosa. 
A Tabela 13 demonstra essas porcentagens em intervalos de dimensões.

Tabela 13 - Granulometria do solo ensaiado

\begin{tabular}{|c|c|c|c|}
\hline Material & Diâmetro $(\mathbf{m m})$ & $\begin{array}{c}\text { Sem defloculante } \\
\text { (\% do material) }\end{array}$ & $\begin{array}{c}\text { Com defloculante } \\
\text { (\% do material) }\end{array}$ \\
\hline Pedregulho grosso & 20,0 a 60,0 & 2,1 & 2,1 \\
\hline Pedregulho médio & 6,0 a 20,0 & 17,3 & 17,3 \\
\hline Pedregulho fino & 2,0 a 6,0 & 13,5 & 13,5 \\
\hline Areia grossa & 0,6 a 2,0 & 17,0 & 14,6 \\
\hline Areia média & 0,2 a 0,6 & 22,3 & 15,2 \\
\hline Areia fina & 0,06 a 0,2 & 17,2 & 16,4 \\
\hline Silte & 0,002 a 0,06 & 10,4 & 12,0 \\
\hline Argila & $<0,002$ & 0,2 & 8,9 \\
\hline \multicolumn{2}{|c|}{ Total } & $\mathbf{1 0 0 , 0}$ & $\mathbf{1 0 0 , 0}$ \\
\hline
\end{tabular}

Fonte: Laboratório de Geotecnia do UniCEUB

\subsection{MASSA ESPECÍFICA REAL DOS GRÃOS}

Para a obtenção de parâmetros de classificação do solo estudado optou-se em verificar a massa específica real dos grãos (Gs) do solo ensaiado, que é apresentada na Tabela 14.

Tabela 14 - Resultado do ensaio de massa específica real dos grãos

\begin{tabular}{|c|c|c|c|}
\hline \multicolumn{5}{|c|}{ Massa especifica dos grãos \# 2mm } \\
\hline Ensaio com picnômetro: & $\mathbf{A}$ & $\mathbf{B}$ & $\mathbf{C}$ \\
\hline Picnômetro ${ }^{\circ}$ & $\mathbf{2}$ & $\mathbf{9}$ & $\mathbf{1 4}$ \\
\hline Temperatura $\left({ }^{\circ} \mathrm{C}\right)$ & $\mathbf{2 7 , 0}$ & $\mathbf{2 6 , 6}$ & $\mathbf{2 6 , 5}$ \\
\hline Pic. + água $(\mathrm{g})$ & 693,79 & 673,32 & 660,68 \\
\hline Pic. + água + solo(g) & $\mathbf{7 3 0 , 9 3}$ & $\mathbf{7 1 0 , 2 7}$ & $\mathbf{6 9 8 , 3 6}$ \\
\hline G $(\mathrm{g} / \mathrm{cm} 3)$ & 2,67 & 2,65 & 2,74 \\
\hline & & $\mathbf{G}_{\mathbf{s}}:$ & $\mathbf{2 , 6 8}$ \\
\cline { 3 - 4 }
\end{tabular}

Fonte: Laboratório de Geotecnia do UniCEUB

O valor do Gs encontrado $\left(2,66 \mathrm{~g} / \mathrm{cm}^{3}\right)$, está de acordo com o valor comumente encontrado no solo brasileiro, que está entre $2,60 \mathrm{~g} / \mathrm{cm}^{3}$ e $2,80 \mathrm{~g} / \mathrm{cm}^{3}$.

\subsection{LIMITES DE ATTERBERG}

$\mathrm{Na}$ Tabela 15 são apresentados os resultados do Limite de Liquidez (LL), obtido através do ensaio com secagem na estufa. 
Tabela 15 - Resultados do Limite de Liquidez

\begin{tabular}{|l|c|c|c|c|c|}
\hline \multicolumn{7}{|c|}{ LIMITE DE LIQUIDEZ } \\
\hline $\mathrm{N}^{\circ}$ da capsula & 7 & 9 & 12 & 41 & 104 \\
\hline $\mathrm{N}^{\circ}$ de golpes & 37 & 31 & 27 & 22 & 17 \\
\hline tara $(\mathrm{g})$ & 15,75 & 14,28 & 13,45 & 12,94 & 16,91 \\
\hline tara $+\mathrm{SH}(\mathrm{g})$ & 41,3 & 31,63 & 34,35 & 40,96 & 49,93 \\
\hline tara + SS (g) & 33,28 & 26,03 & 27,45 & 31,43 & 38,47 \\
\hline Umidade $(\%)$ & $\mathbf{4 5 , 7 5}$ & $\mathbf{4 7 , 6 6}$ & $\mathbf{4 9 , 2 9}$ & $\mathbf{5 1 , 5 4}$ & $\mathbf{5 3 , 1 5}$ \\
& & LL (\%): & $\mathbf{4 9 , 8 1}$ \\
\hline
\end{tabular}

Fonte: Laboratório de Geotecnia do UniCEUB

A Figura 26 é um gráfico que mostra a curva do Limite de Liquidez com o número de golpes em escala logarítmica, conforme estipulado pela norma NBR 6459/84.

Figura 26 - Curva do Limite de Liquidez

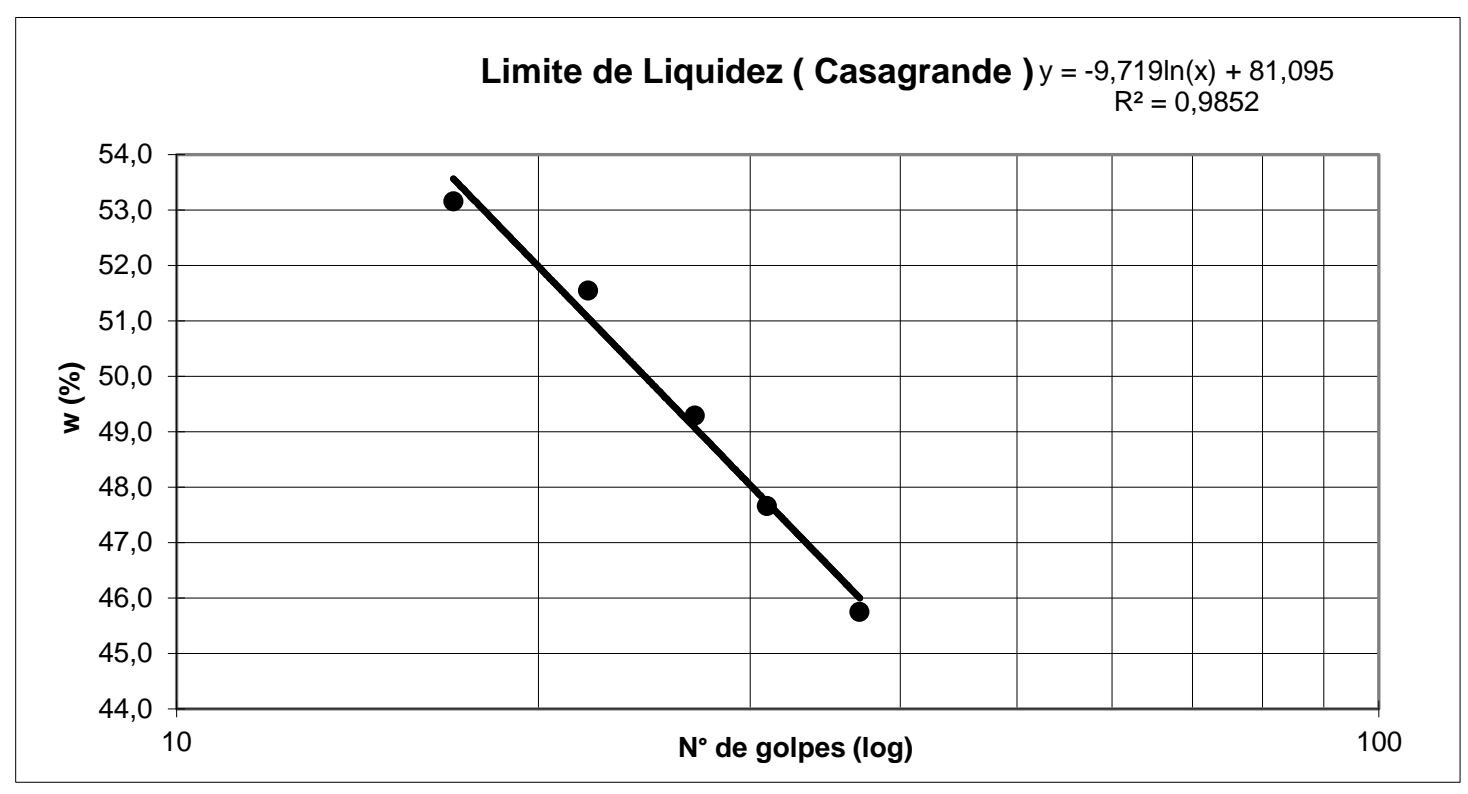

Fonte: Laboratório de Geotecnia do UniCEUB

Conforme mostra a Tabela 15, o Limite de Liquidez do solo estudado foi de $49,81 \%$, o que o coloca dentro dos parâmetros permitidos pela norma do Departamento Nacional de Estradas de Rodagem - Métodos de Ensaio (DNER-ME 122/94), cujo Limite de Liquidez aceito vai até $150 \%$.

A Tabela 16 apresenta os valores obtidos no ensaio de Limite de Plasticidade. 
Tabela 16 - Resultado do Limite de Plasticidade

\begin{tabular}{|l|c|c|c|c|c|}
\hline \multicolumn{7}{|c|}{ LIMITE DE PLASTICIDADE } \\
\hline$N^{\circ}$ da capsula & 60 & 66 & 83 & 98 & 124 \\
\hline tara $(\mathrm{g})$ & 5,88 & 5,72 & 5,63 & 6,04 & 6,08 \\
\hline tara $+\mathrm{SH}(\mathrm{g})$ & 7,77 & 7,59 & 8,19 & 7,63 & 10,74 \\
\hline tara + SS $(\mathrm{g})$ & 7,31 & 7,17 & 7,58 & 7,25 & 9,63 \\
\hline Umidade $(\%)$ & $\mathbf{3 2 , 1 7}$ & $\mathbf{2 8 , 9 7}$ & $\mathbf{3 1 , 2 8}$ & $\mathbf{3 1 , 4 0}$ & $\mathbf{3 1 , 2 7}$ \\
\hline \multicolumn{2}{|l}{} & LP(\%): & $\mathbf{3 1 , 0 2}$ \\
\hline
\end{tabular}

Fonte: Laboratório de Geotecnia do UniCEUB

\subsection{1 Índice de Plasticidade}

O índice de plasticidade (IP) é a diferença entre o limite de liquidez e o limite de plasticidade de um solo (DAS, 2012). A Tabela 17 apresenta o valor do Índice de Plasticidade.

Tabela 17 - Limites de Atterberg - Índice de Plasticidade

\begin{tabular}{l}
\hline \multicolumn{2}{c}{ ÍNDICE DE PLASTICIDADE } \\
\hline LL (\%) - LP (\%) \\
\hline \multicolumn{2}{c}{$49,81(\%)-31,02(\%)$} \\
\hline IP $(\%)=\mathbf{1 8 , 7 9}(\%)$ \\
\hline
\end{tabular}

Fonte: Laboratório de Geotecnia do UniCEUB

Na Tabela 18 é apresentada a classificação de Burmister quanto ao Índice de Plasticidade (BURMISTER, 1949 apud DAS, 2007).

Tabela 18 - Classificação de Burmister para o Índice de Plasticidade

\begin{tabular}{cc}
\hline IP $(\%)$ & Descrição \\
\hline 0 & Não-plástico \\
$1-5$ & Ligeiramente Plástico \\
$5-10$ & Plasticidade baixa \\
$10-20$ & Plasticidade média \\
$20-40$ & Plasticidade alta \\
$>40$ & Plasticidade muito alta \\
\hline
\end{tabular}

Fonte: (BURMISTER, 1949 apud DAS, 2007)

De acordo com a Tabela 18 o solo é classificado como um solo de plasticidade média, por possuir valor de IP igual a 18,28\%.

A Tabela 19 mostra um resumo dos limites de Atterberg do solo utilizado nessa pesquisa. 
Tabela 19 - Limites de Atterberg

\begin{tabular}{ccccc}
\hline Solo & LL (\%) & LP (\%) & IP (\%) & Descrição \\
\hline Areia siltosa & 49,81 & 31,53 & 18,28 & $\begin{array}{c}\text { Plasticidade } \\
\text { média }\end{array}$ \\
\hline
\end{tabular}

Fonte: Laboratório de Geotecnia do UniCEUB

\subsection{IDENTIFICAÇÃO E DESCRIÇÃO EXPEDITA DE SOLOS, METODOLOGIA MCT}

Os resultados dos ensaios de MCT do solo estudado são demostrados na Tabela 20.

Tabela 20 - Valores do MCT

\begin{tabular}{|c|c|c|c|c|c|c|}
\hline \multicolumn{5}{|c|}{ CONTRAÇÃo } & \multirow{2}{*}{ ANEL N } & \multirow{2}{*}{ Contração } \\
\hline \multirow{2}{*}{ ANEL N } & DIÂMETRO & DIÂMETRO & TEMPO DE & PENETRAÇÃO & & \\
\cline { 2 - 5 } & ANEL & PASTILHA & ASCENSÃO DE ÁGUA (seg) & $(\mathbf{m m})$ & $\mathbf{1}$ & 0,9733 \\
\hline $\mathbf{1}$ & 18,87 & 17,90 & 260 & 1,00 & $\mathbf{2}$ & 0,9867 \\
\hline $\mathbf{2}$ & 18,92 & 17,93 & 275 & 1,00 & $\mathbf{3}$ & 0,8867 \\
\hline $\mathbf{3}$ & 18,88 & 17,99 & 295 & 1,00 & Média & 0,9489 \\
\hline
\end{tabular}

Fonte: Laboratório de Geotecnia do UniCEUB

A bola seca não esmagou com a pressão do dedão sobre a bola contra uma placa dura, sendo assim a resistência considerada muito alta.

Observando-se que o valor da penetração foi de $1 \mathrm{~mm}$ e o valor encontrado da contração diametral (c') foi de 1,354, é possível classificar o solo de acordo com a carta de classificação apresentada na Erro! Fonte de referência não encontrada. localizada na revisão teórica dessa pesquisa. Dessa forma, o solo é classificado no ensaio de MCT como arenoso laterítico-argiloso laterítico (LA'-LG').

\subsection{COMPACTAÇÃO}

A Figura 27 mostra as curvas de compactação obtidas nos ensaios com solo natural e solo com adição de $2 \%, 4 \%, 6 \%$ e $8 \%$ de lignosulfonato. Em todas as curvas foi realizada a compactação na energia intermediaria. 
Figura 27 - Comparativo entre a compactação do solo natural e do solo com suas respectivas adições.

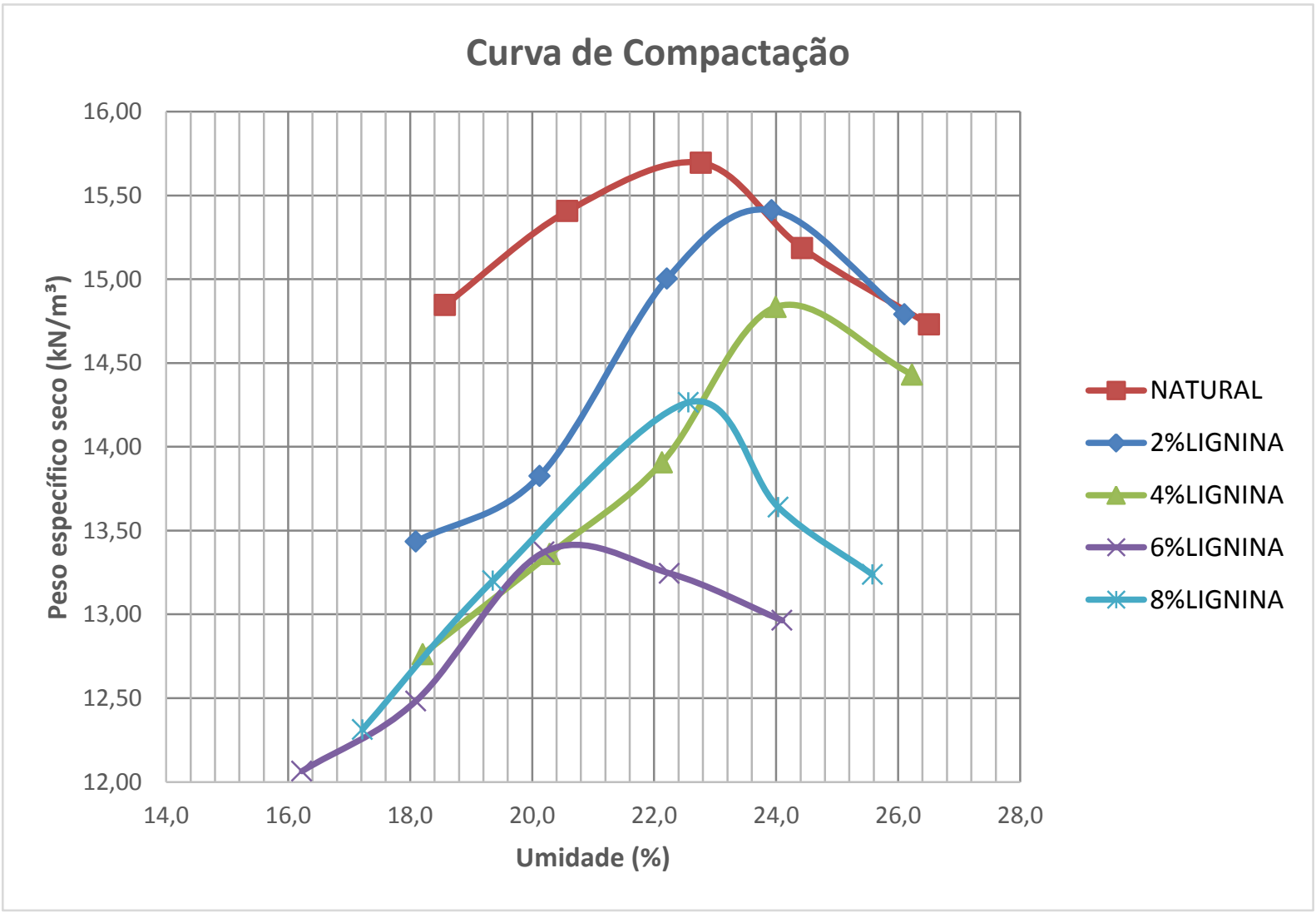

Fonte: Elaborada pelo autor

Observa-se que para as amostras ensaiadas o solo natural apresentou maior peso especifico seco máximo de $15,69 \mathrm{kN} / \mathrm{m}^{3}$ com uma umidade ótima no valor de $22,8 \%$. Verifica-se que, a presença do lignosulfonato gerou uma mudança considerável na umidade ótima, justamente pelo fato dele ser um material mais fino que o solo. Como materiais mais finos absorvem mais agua, isso fez com que a umidade ótima de cada curva variasse. Para as curvas com a mistura de solo com $2 \%$ de lignina e solo com $4 \%$ de lignina seguiram um comportamento semelhante em relação ao solo natural, um aumento da umidade ótima com o aumento do teor da lignina. Já para os teores de mistura com $6 \%$ e $8 \%$ de lignina a umidade ótima teve uma redução em comparação com as outras amostras. Outro fator a ser observado é quanto ao peso especifico, pois quanto mais lignosulfonato se adiciona ao solo, a tendência é que peso especifico diminua, pois estamos adicionando um material mais leve que o solo. 
A Tabela 21 apresenta os resultados de peso especifico seco máximo e umidade ótima encontrada a partir dos experimentos de compactação realizados.

Tabela 21 - Relação da umidade ótima e peso especifico seco máximo para todas as amostras ensaiadas

\begin{tabular}{c|c|c}
\hline Material Estudado & Peso específico seco $\left(\mathrm{kN} / \mathrm{m}^{3}\right)$ & Umidade ótima (\%) \\
\hline Solo Natural & 15,69 & 22,77 \\
\hline Solo Natural com 2\% Lignina & 15,41 & 23,92 \\
\hline Solo Natural com 4\% Lignina & 14,83 & 23,99 \\
\hline Solo Natural com 6\% Lignina & 13,37 & 20,20 \\
\hline Solo Natural com 8\% Lignina & 14,27 & 22,56 \\
\hline
\end{tabular}

Fonte: Elaborada pelo autor

A Figura 28 apresenta um gráfico que demonstra o peso específico seco máximo, em $\mathrm{kN} / \mathrm{m}^{3}$, dos corpos de prova com umidade (\%) ótima das curvas de compactação.

Figura 28 - Peso específico máximo seco x umidade ótima parar todas as curvas de compactação ensaiados.

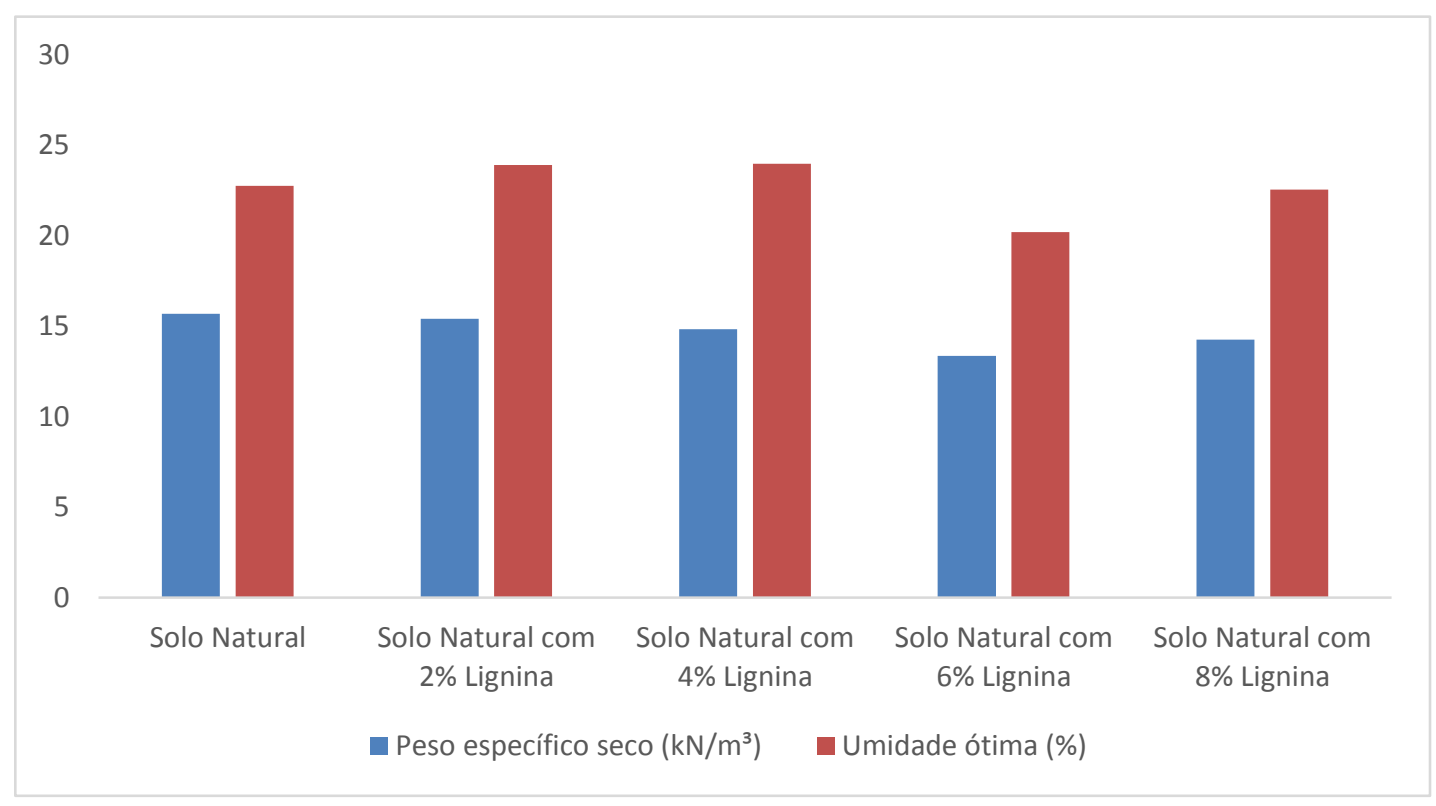

Fonte: Elaborada pelo autor

A Figura 28 mostra que o lignosulfonato ao ser adicionado ao solo, proporciona uma gradativa redução no peso específico seco máximo dos corpos de prova na umidade ótima. Observa-se uma redução de aproximadamente $9,5 \%$ ao se comparar os valores de peso especifico seco máximo do solo natural que apresentou maior valor 
que a amostra com maior adição de lignosulfonato (8\%). Já para o que apresentou maior redução de peso específico ficou para a amostra com adição de $6 \%$ de lignosulfonato no valor de $17,35 \%$. Tais reduções do peso especifico é uma fator positivo com relação a sobrecarga do aterro (barragem) na fundação.

\subsection{PENETRAÇÃO}

Nos corpos de prova obtidos nos ensaios de compactação foram feitos também ensaios de penetração, para obtenção do Índice de Suporte Califórnia - ISC para cada amostra e umidade. A Figura 29 apresenta os resultados dos experimentos de penetração para as amostras nas umidades de solo natural compactados na energia intermediaria.

Figura 29 - Apresenta os resultados para penetração x pressão do solo natural.

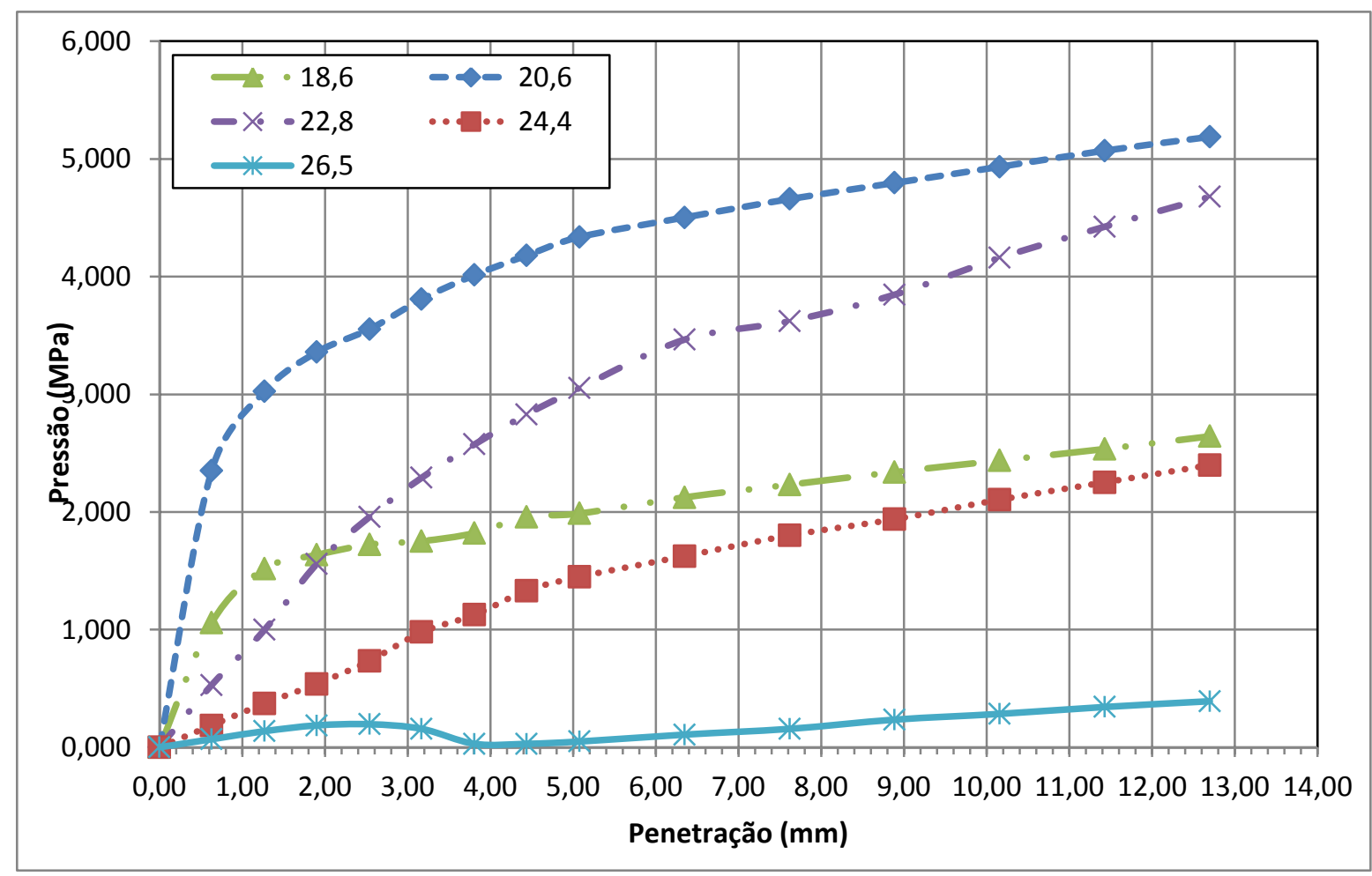

Observa-se na Figura 29 que para a melhor penetração, 20,6\% de umidade não foi o que apresentou o maior peso especifico seco máximo da curva de compactação para a umidade ótima de $22,8 \%$. Para análise comparativa dos resultados do solo natural com as misturas, foi escolhido o melhor resultado, sendo ele, com a umidade de $20,6 \%$, que se destacou por obter um I.S.C de $51,5 \%$ para a penetração de $2,54 \mathrm{~mm}$. 
A Figura 30 mostra o gráfico da pressão x penetração dos corpos de prova com adição de $2 \%$ de lignosulfonato compactados na mesma energia compactada para 0 solo natural.

Figura 30 - Ensaio de penetração x pressão do solo com adição de $2 \%$ lignosulfonato.

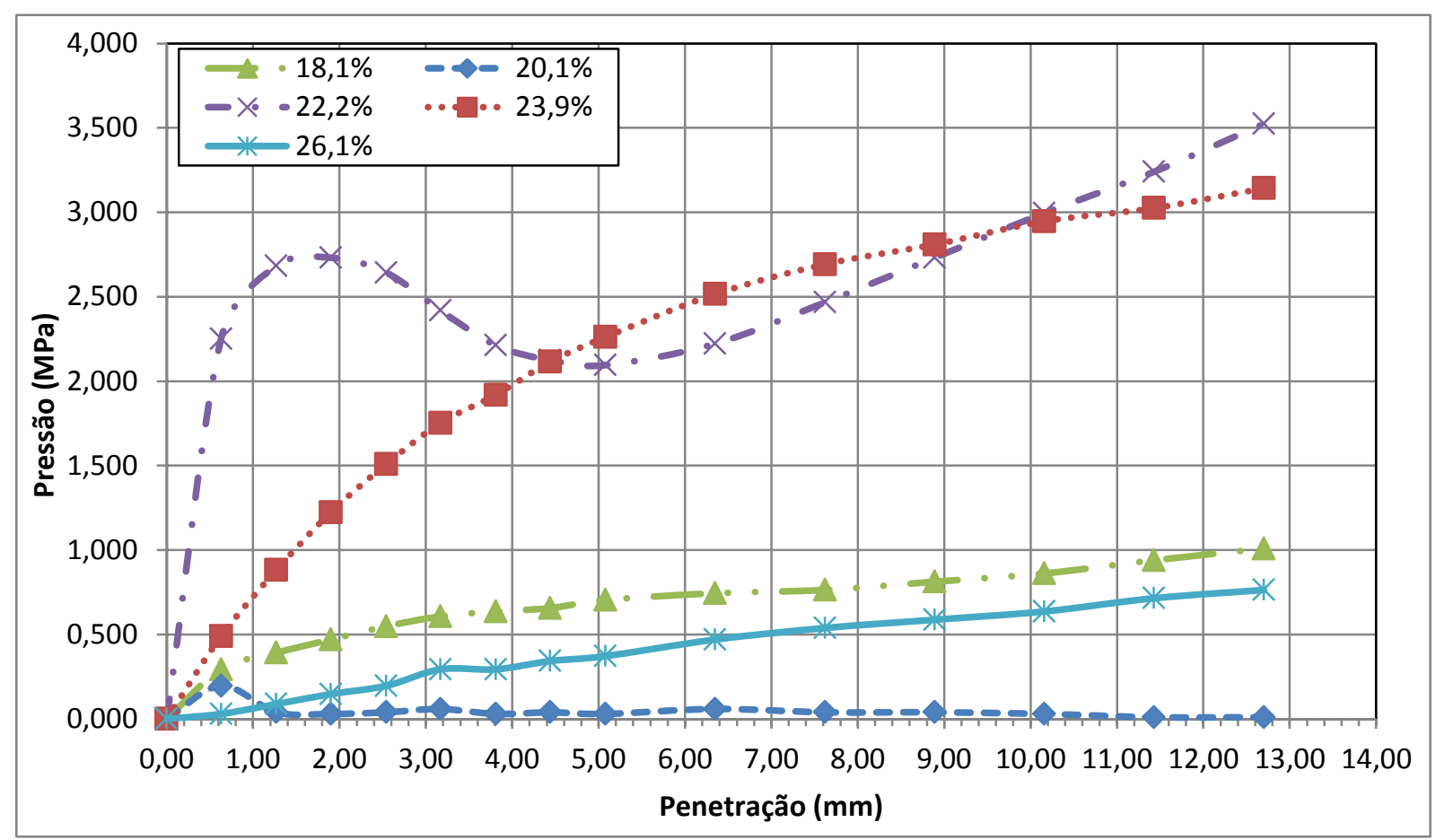

Fonte: Elaborada pelo autor

Verifica-se na Figura 30 que o melhor valor para as penetrações das amostras ensaiadas foi de $23,9 \%$ de umidade. O I.S.C. com adição de $2 \%$ de lignina teve um rendimento menor, apresentando um resultado de $38,3 \%$, ou seja, houve uma diminuição de $24,7 \%$ quando comparado com o I.S.C de melhor resultado do solo natural. 
Figura 31 mostra o resultado do ensaio de penetração versus pressão para os moldes de solo com adição de $4 \%$ de lignosulfonato compactados na energia intermediaria.

Figura 31 - Ensaio de penetração versus penetração do solo com adição de 4\% lignosulfonato.

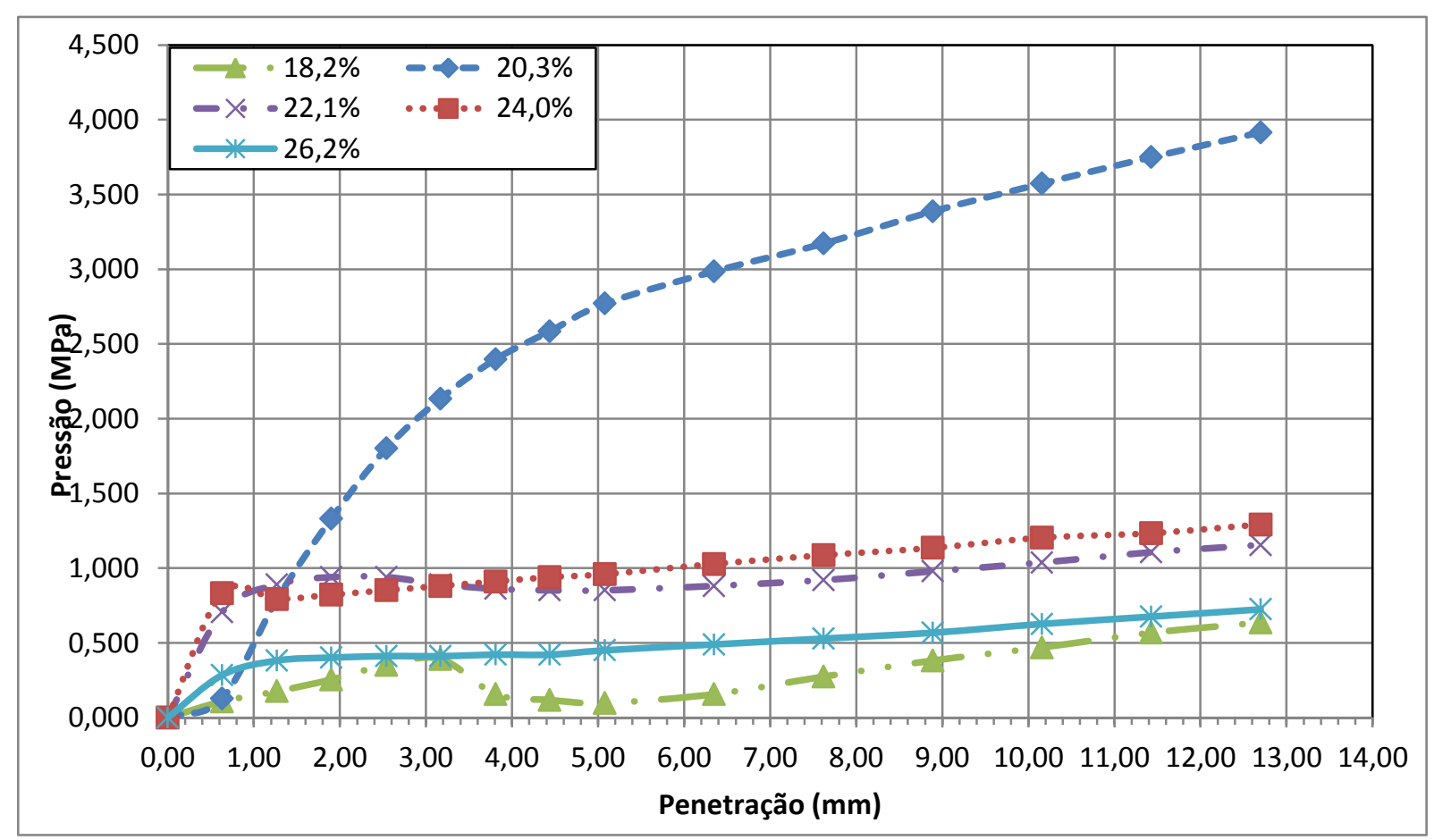

Fonte: Elaborada pelo autor

Para essa mistura com adição de $4 \%$ de lignosulfonato apresentado na Figura 31 observa-se que a umidade de $20,3 \%$ apresentou o melhor resultado dentre todos os pontos da curva de compactação sendo esse valor a umidade ótima. O I.S.C. encontrado nessa umidade foi de $26,10 \%$, mostrando então que até essa adição de lignosulfonato como solução de melhoramento a mistura não apresentou melhora na resistência a penetração quando comparado ao solo natural. Apresentando uma redução de 49,32\% em relação ao solo natural. 
A Figura 32 apresenta o resultado do ensaio de penetração do pistão versus pressão para os moldes de solo com adição de $6 \%$ de lignosulfonato compactados na energia intermediaria.

Figura 32 - Ensaio de penetração versus pressão do solo com adição de 6\% lignosulfonato.

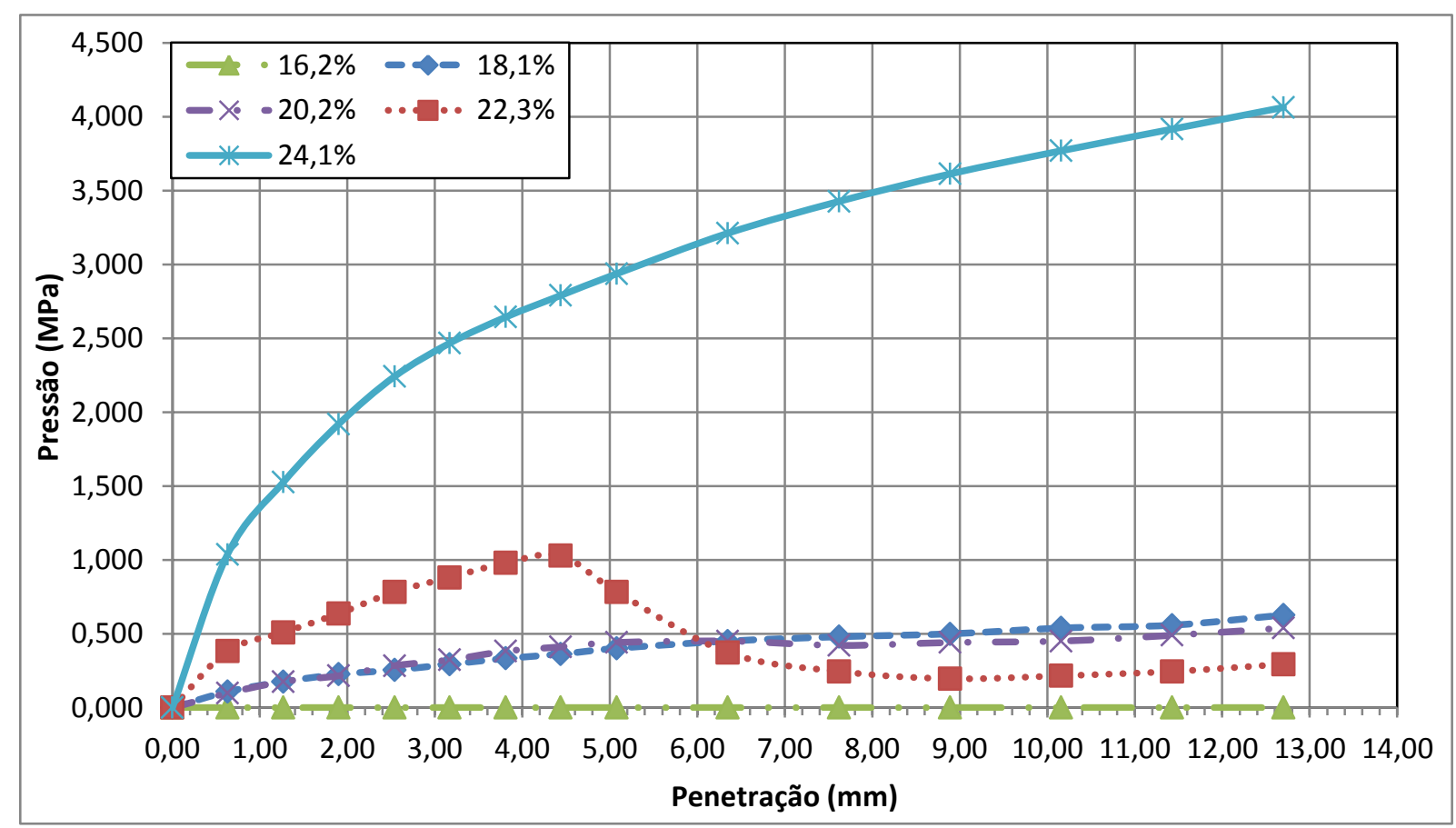

Fonte: Elaborada pelo autor

A Figura 32 apresenta as penetrações das amostras compactadas cujo melhor desempenho entre elas foi com $24,1 \%$ de umidade. É importante observar duas considerações nesse gráfico, à primeira é que novamente o I.S.C de melhor resultado não foi o mesmo ponto de umidade ótima da compactação. A segunda observação é que para a umidade de $24,1 \%$ apresentou um I.S.C de $32,5 \%$, valor maior que o encontrado para adição de $4 \%$ de lignosulfonato, porém menor ainda que o valor obtido para adição de $2 \%$ de lignosulfonato. 
A Figura 33 mostra o resultado do ensaio de penetração versus pressão para os moldes de solo com adição de $8 \%$ de lignosulfonato compactados na energia intermediaria.

Figura 33 - Ensaio de penetração versus pressão do solo com adição de 8\% lignosulfonato.

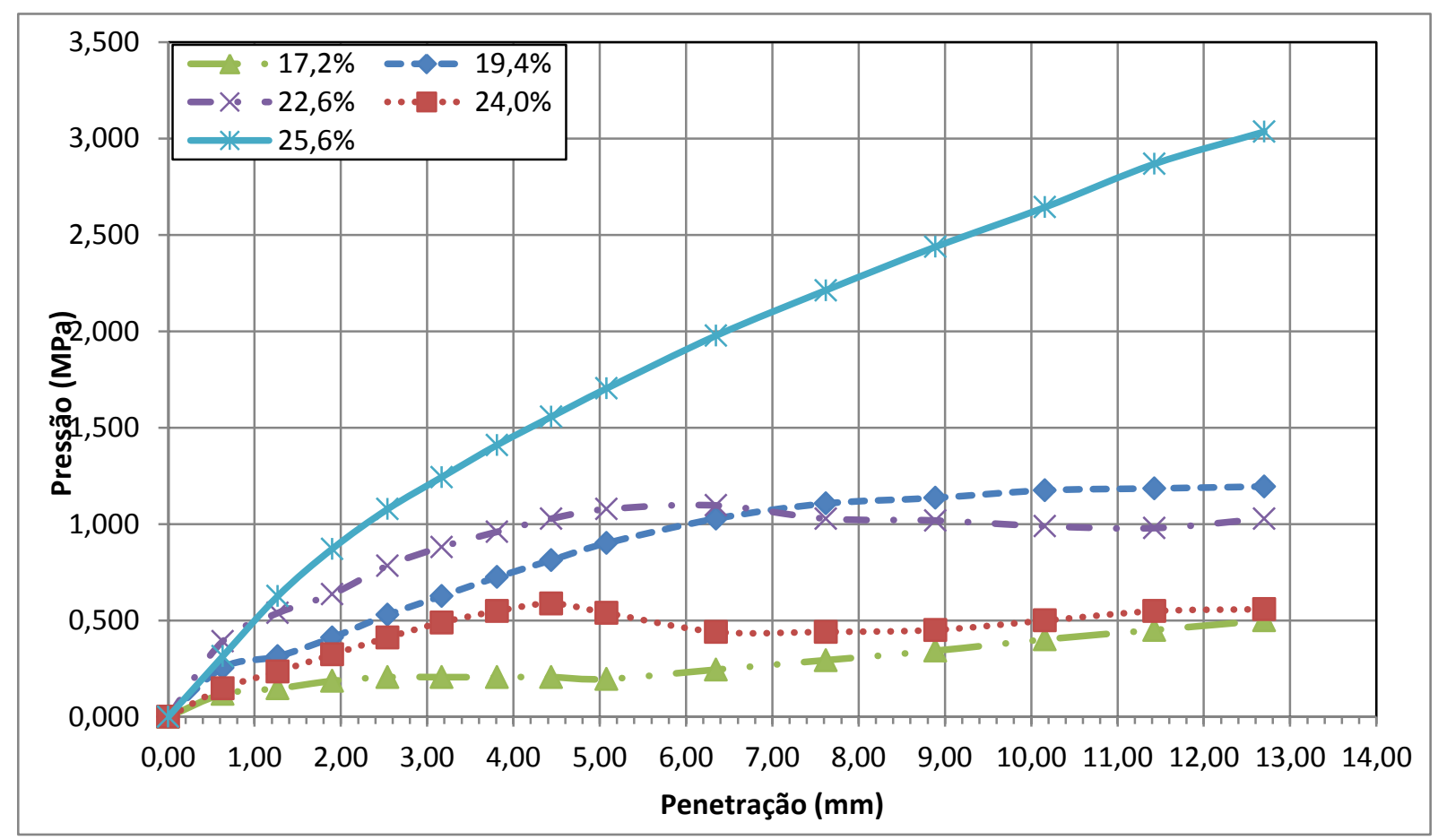

Fonte: Elaborada pelo autor

Verifica-se na Figura 33 que a umidade com melhor desempenho para a penetração das amostras com teor de $8 \%$ de lignosulfonato foi de $25,6 \%$, apresentando um I.S.C de $15,6 \%$ mostrando ser o menor valor dentre os experimentos realizados com o solo natural e com adição de lignosulfonato compactados.

De forma a comparar os resultados à Figura 34 mostra 0 gráfico pressão $x$ penetração das amostras de solos ensaiados com e sem adição de lignina dos ensaios de compactação para os melhores resultados de cada mistura. 
Figura 34 - Comparativo entre os melhores resultados de I.S.C dentre todas as amostras dos ensaios de compactação das misturas e solo natural.

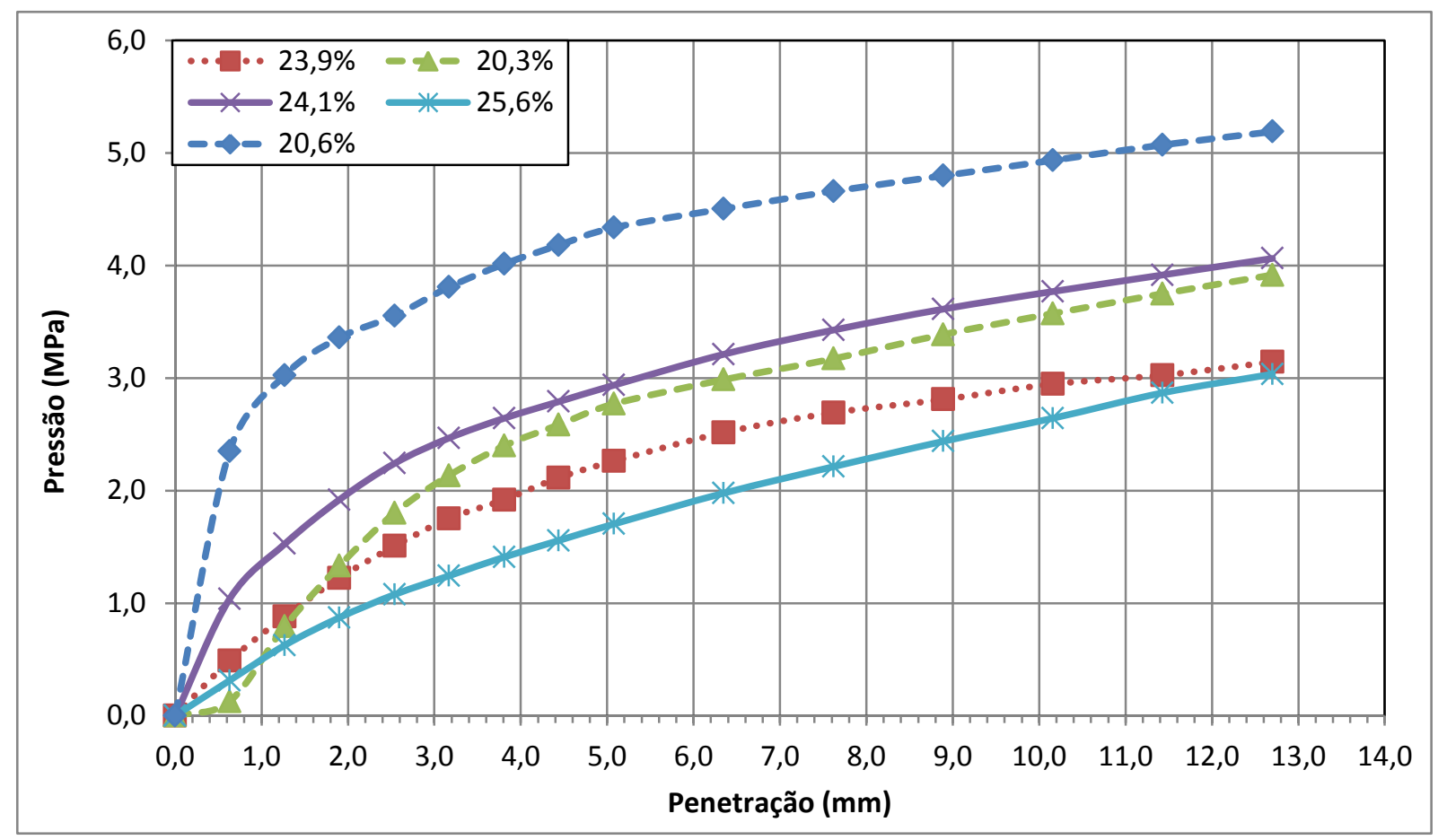

Fonte: Elaborada pelo autor

A Figura 34 mostra que para as amostras ensaiadas tanto para o solo natural quanto para as misturas a que apresentou melhor resultado foi a do solo natural com umidade de $20,6 \%$ e I.S.C de $51,5 \%$. Apesar de ter ocorrido uma diminuição na resistência à penetração (I.S.C) nos corpos de prova com adição de 2\%, 4\%, 6\% e $8 \%$ de lignosulfonato em comparação do solo natural esses resultados de I.S.C estão de acordo com as especificações da norma do DNIT 108/2009 - Aterros Especificação de Serviço, o I.S.C. onde o material a ser utilizado como corpo do aterro deve ser igual ou maior que $2 \%$ de I.S.C, assim todas as amostras ensaiadas 
atendem a esse parâmetro, no entanto vale ressaltar que para o corpo de aterro a energia aplicada deve ser a energia normal, e para essa pesquisa a energia utilizada foi a intermediária.

De acordo com a norma 108/2009 do DNIT também apresenta a definição da camada final do aterro como sendo a parte que possui $60 \mathrm{~cm}$ de espessura, e se situa sobre o copo do aterro para obras de infraestrutura terrestre (Figura 35).

Figura 35 - Composição do aterro

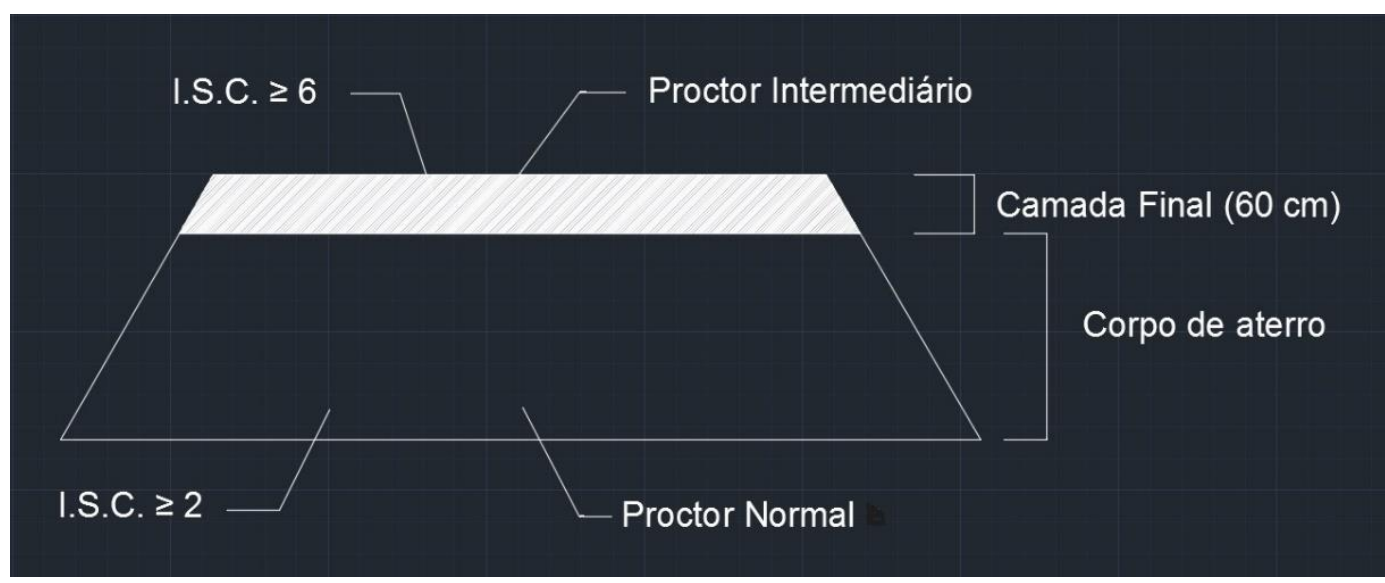

Fonte: Elaborada pelo autor

Essa camada deve ser compactada com energia intermediária. O I.S.C. do material utilizado na camada final deve ser igual ou maior que 6\%. Assim, conclui-se que, de acordo com essa exigência, os resultados encontrados com adição de lignosulfonato podem ser empregados nessa camada, uma vez que o menor dos valores das misturas atingiu um I.S.C. de 15,6\% (8\% de lignosulfonato) quando compactado com energia intermediária. Levando em consideração as tensões geradas pelo aterro da barragem na fundação, a mistura apresentou considerações favoráveis quanto ao peso do aterro para a distribuição do acréscimo de carga na fundação apresentando diminuição para a tensão final no pé da fundação. 


\subsection{CISALHAMENTO}

De forma a comparar os parâmetros de resistência da coesão ao cisalhamento direto à Figura 36 apresenta um comparativo entre os valores da coesão e da umidade de cada ponto das curvas de compactação.

Figura 36 - Influência das umidades na coesão das amostras ensaiadas.

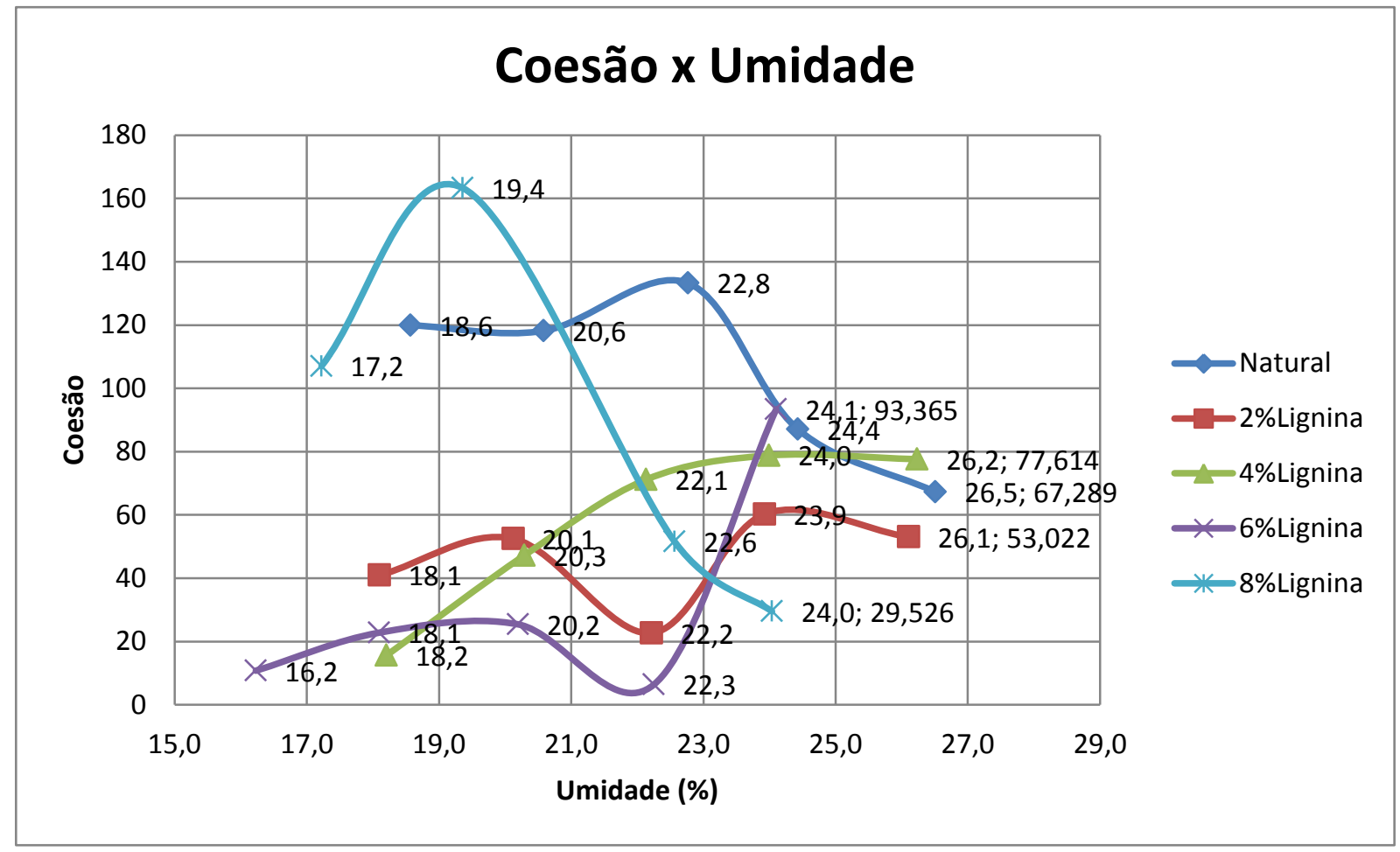

Fonte: Elaborada pelo autor

Como pode ser observado na Figura 36, a coesão de 163,3 kPa do solo com adição de $8 \%$ de lignosulfonato para umidade de $19,4 \%$, apresentou maior resultados comparado com as demais amostras ensaiadas, vale ressaltar que não foi a 
umidade ótima da curva de compactação. Em comparação aos resultados apresentados para as amostras ensaiadas para o solo natural o melhor resultado obtido foi para a umidade de $22,8 \%$ com uma coesão no valor de $133,2 \mathrm{kPa}$, sendo o valor da umidade ótima da curva de compactação, divergindo do melhor valor de I.S.C que foi para a umidade de $20,6 \%$. Sendo assim a adição do lignosulfonato apresentou uma melhoria na resistência do solo misturado em comparação do solo natural.

Outro parâmetro a ser verificado foi o ângulo de atrito obtido também do ensaio de cisalhamento direto. Desta forma a Figura 37 apresenta uma relação entre os ângulos de atrito e as coesões dos melhores resultados obtidos nos valores da coesão para cada tipo de amostra ensaiada.

Figura 37 - Influência do ângulo de atrito na coesão

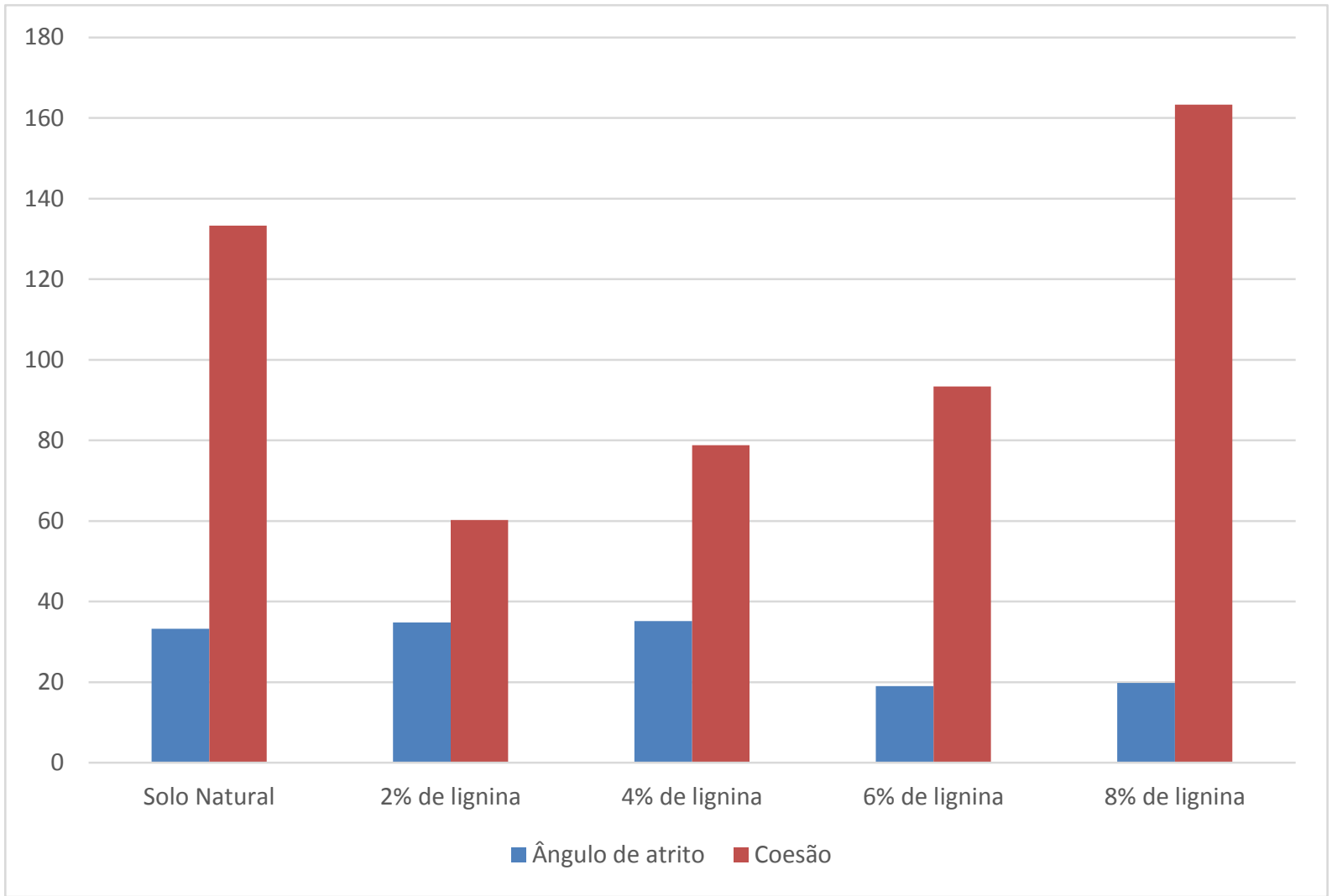

Fonte: Elaborada pelo autor 
Analisando a Figura 37 observamos que os valores do ângulo de atrito da mistura com adição de $2 \%$ e $4 \%$ de lignosulfonato em comparação ao solo natural houve um aumento de $4,7 \%$ e $5,8 \%$ respectivamente. Já para as misturas de $6 \%$ e $8 \%$ de lignosulfonato houve um decréscimo em relação ao solo natural e das outras misturas de $2 \%$ e $4 \%$ de lignosulfonato. Essa redução pode ter sido em função do percentual a mais do material fino incorporado.

\section{CONCLUSÃO}

O projeto de pesquisa teve como objetivo verificar se o acréscimo de lignosulfonato como mistura no solo residual típico do Distrito Federal apresentaria melhorarias quanto aos parâmetros de resistências de penetração e cisalhamento direto em comparação ao solo natural de forma a verificar sua influencia nos fatores de segurança para aterros compactados com solo natural e com mistura de solo e lignosulfonato de forma a compara-lo.

Sendo assim observou-se que os valores obtidos para o solo natural apresentou resultados satisfatórios quanto à resistência a penetração e cisalhamento direto podendo ser aplicado para obras de barragens como aterros de infraestrutura terrestre tendo como melhores valores I.S.C de $51,5 \%$. Para os valores de resistência ao cisalhamento direto foram obtidos os valores de coesão de 133,3 kPa e ângulo de atrito de $33,3^{\circ}$. Vale ressaltar que para alguns valores de pesos específico máximo seco na umidade ótima não representaram os melhores valores de I.S.C como no caso do solo natural, $4 \%$ de lignosulfonato, $6 \%$ e $8 \%$ de lignosulfonato. 
Para as mistura realizadas com lignosulfonato nos teores de $2 \%, 4 \%, 6 \%$ e $8 \%$ os valores obtidos de I.S.C apresentaram resultados menores em relação aos valores do solo natural. Sendo que para a mistura de $2 \%$ de lignosulfonato apresentou 0 melhor resultados entre as mistura com valor de $38,3 \%$ no entanto $7,4 \%$ menor que de I.S.C do solo natural.

Um fator importante que se deve levar em consideração são os pesos específicos secos máximos encontrados nos ensaios de compactação para todas as umidades onde se observa uma redução dos mesmos proporcionais aos percentuais com adição de lignosulfonato. Quanto as cargas geradas pelo acréscimo de tensões devido ao carregamento dos aterros na fundação da barragem e de seu maciço, tornando o aterro mais leve apresentando como um item importante na estabilidade do talude.

Quanto aos parâmetros de resistência ao cisalhamento direto observou-se que o incremento do lignosultonato melhorou tais fatores em comparação ao solo natural como foi o caso da mistura com 8\% de lignosulfonato apresentando valores de 163,3 kPa de coesão e ângulo de atrito no valor de 19,8, já que no solo natural apresentou coesão de $133,3 \mathrm{kPa}$ e ângulo de atrito de 33,3을 demostrando um melhoria dos parâmetros de cisalhamento direto e consequentemente dos fatores de segurança na estabilidade de taludes. Podendo ser empregado a lignosulfonato como mistura de material para a construção de barragens e aterros, ressaltando ainda já observado a redução de sua densidade com o percentual de lignosulfonato. Esse ganho de resistência da coesão pode ser devido a uma reação química de cimentação do lignosulfonato acima de $8 \%$. 


\section{REFERÊNCIAS}

[Online] / A. DNPM // Departamento Nacional de Produção Mineral. - Ministério de Minas e Energia, 04 de 02 de 2015. - 30 de 08 de 2017. - http://www.dnpm.gov.br.

NBR 6457. Amostra de solos - Preparação para ensaio de caracterização e compactação. Rio de Janeiro. 1986.

. NBR 6459. Solo - determinação do limite de liquidez. Rio de Janeiro. 1984.

NBR 6502. Rochas e solos - Terminologia. Rio de Janeiro. 1995.

. NBR 6508. Grãos de Solos que Passaram na Peneira de 4,8 mm Determinação da Massa Específica. Rio de Janeiro. 1984.

NBR 7180. Solo - Determinação do limite de Plasticidade. Rio de Janeiro. 1984

NBR 7181. Solos - Análise Granulométrica. Rio de Janeiro. 1984.

NBR 7182. Solos - Ensaio de Compactação. Rio de Janeiro. 1986. 
. NBR 9604. Abertura em poços e trincheiras de inspeção em solo para retirar amostra deformada e indeformada. Rio de Janeiro. 1986.

. NBR 9895. Índice Suporte Califórnia - CBR. Rio de Janeiro. 1987.

. NORMA DNIT 108/2009 - Aterros - Especificação de Serviço. Rio de Janeiro. 2009a.

NORMA DNIT 138/2010 - ES: Pavimentos flexíveis - Reforço do subleito - Especificação de serviço. Rio de Janeiro. 2010b.

NORMA DNIT 143/2010 - ES: Pavimentação - Base de solo-cimento Especificação de serviço. Rio de Janeiro. 2010a.

Aálise de Material Fresado Quanto a Viabilidade nop Uso em Reforço e Camada de Base [Livro] / A. Mendes Dênis Viana. - Brasília : lesplan, 2012.

ABDULLAH, C.H. (2006). Evaluation of Load Transfer Plataforms and Their Design Methods for Embankments Supported on Geopiers. Dissertação de Doutoramento, University of Wisconsin, 2006.

ABNT - ASSOCIAÇÃO BRASILEIRA DE NORMAS TÉCNICAS. NBR 5734. Peneiras para Ensaio. Rio de Janeiro. 1989.

Análise de estabilidade de barragem de rejeitos em planta industrial de Poços de Caldas - MG. [Livro] / A. Branquinho Luis Otávio Simões. - Poços de Caldas : Universidade Federal de Alfenas, 2014.

Análise probabilística de estabilidade de taludes em barragem de rejeitos [Livro] / A. Rezende Diego Alves de. - Rio de Janeiro : UFRJ/ Escola Politécnica, 2013.

ASTM, A. C578-16 "Standard Specification for Rigid, Cellular Polystyrene Thermal Insulation", ASTM International, West Conshohocken, PA, 2016, DOI: 10.1520/C0578-16.

ASTM, A. D6817-15 “Standard Specification for Rigid Cellular Polystyrene Geofoam" (Normas de especificação para células rígidas de poliestireno 
expandido), ASTM Internacional, West Conshohocken, PA, 2003, DOI: 10.1520/C0033-03.

AZEVÊDO, André Luis Cairo. Estabilização de solos com adição de cal - um estudo a respeito da reversibilidade das reações que acontecem após a adição de cal. 2010. 114 f. Dissertação (Mestrado em Geotecnia) - Universidade Federal de Ouro Preto - UFOP, Ouro Preto, 2010.

BASF Styropor Technical Information

BERNUCCl et al. Pavimentação Asfáltica: Formação básica para engenheiros. Rio de Janeiro: Petrobras, 2008.

CAPUTO, H. P. Mecânica dos Solos e Suas Aplicações. 3ª ed. Rio de Janeiro: Livros Técnicos e Cientificos Editora S.A., Volume 1, 2007.

Caracterização e classificação geral de solos para pavimentação: limitações dos métodos tradicionais, apresentação de uma nova sistemática. [Livro] / A. NOGAMI J.S. e VILLIBOR D.F.. - Belo Horizonte : 15ª Reunião Anual de Pavimentação, 1980.

CNT - CONFEDERAÇÃO NACIONAL DO TRANSPORTE. Pesquisa CNT de rodovias 2013: relatório gerencial, Brasília, CNT; SEST; SENAT, 2013.

CODUTO D., 2011. Geotechnical engineering: Principles and practices. (Engenharia Geotécnica: Princípios e práticas). Upper Saddle River, NJ. Pearson Higher Education Inc. p.527-564.

Contribuição ao estudo do comportamento de barragens de rejeito de mineração de ferro [Livro] / A. Araujo Cecília Bhering de. - Rio de Janeiro : UFRJ, 2006.

COUTINHO, Joana de Sousa. Materiais de Construção 2: 1a Parte - Ligantes e Caldas. Faculdade de Engenharia da Universidade do Porto - FEUP. 2006.

CRISTELO, Nuno Miguel Cordeiro. Estabilização de solos residuais graníticos através da adição de cal. Dissertação (Mestrado em Engenharia Civil) - Escola de Engenharia da Universidade do Minho. 2001. 
DAS, Braja M. Fundamentos de engenharia geotécnica. São Paulo: Thomson Learning, 2007.

Determinação do Poder Aglutinante do Lignosulfonato sobre a Peletização [Periódico] / A. Schmidt Alessandra [et al.]. - Concórdia : Ministério da Agricultura, Pecuária e Abastecimento, 2004.

DNER - DEPARTAMENTO NACIONAL DE ESTRADAS DE RODAGEM. DNER-ME 122. Solos - Determinação do limite de liquidez - método de referência e método expedito. Rio de Janeiro. 1994.

DNIT - DEPARTAMENTO NACIONAL DE INFRAESTRUTURA DE TRANSPORTE. Manual de Pavimentação. 3ạ. ed. Rio de Janeiro: DNIT, 2006.

FARIAS, Rodrigo. O Impacto Ambiental na Substituição do Papel Virgem por Papel Reciclado em Embalagens Corrugadas. Trabalho de Conclusão de Curso. Curitiba: UTFPR, 2013.

FORTES, Rita Moura; MERIGHI, João Virgilio e ZUPPOLINI NETO, Alexandre Método das pastilhas para identificação expedita de solos tropicais $-2^{\circ}$ Congresso Rodoviário Português - Lisboa, Portugal, 2002.

Guidicini, G., \& Nieble, C. (1984). Estabilidade de Taludes Naturais e de Escavação. São Paulo: Blucher.

HORVATH, J.S. (1995). "Geofoam Geosynthetic" (Isopor Geosintético), Horvath Engineering, P.C., Scarsdale, N.Y.,

HORVATH, J.S., (1999) Lessons Learned from Failures Involving Geofoam in Roads and Embankments. (Lições Aprendidas de Falhas Envolvendo Isopor em Rodovias e Aterros). Manhattan College School of Engineering Civil Engineering Department

JÚNIOR, Hermenegildo Henrique Soares; FERREIRA, Osmar Mendes. Processos erosivos e perda de solo em estradas vicinais. Universidade Católica de Goiás Departamento de Engenharia - Engenharia Ambiental, Goiânia, 2007. 
KALIYAN, K.; MOREY, R. V. Factors affecting strength and durability of densified biomass products. Biomass \& Bioenergy, Minnesota, v. 33, n. 3, p. 337-359, 2009.

LAVOIE, Fernando Luiz. Estudo do Fenômeno de Fissuramento Sob Tensão (Stress Cracking) em Geomembranas de Polietileno (PE) Virgens e Degradadas. 2015.

Manual de Técnicas de Pavimentação [Livro] / A. SENÇO Wlastermiler de.. - São Paulo : PINI, 2007. - Vol. 1.

MARQUES, Geraldo Luciano de Oliveira. Notas de Aula da Disciplina Pavimentação. Universidade Federal de Juiz de Fora. Juiz de Fora. 2006. 204 f.

Metodologia probabilística e observacional aplicada a barragens de rejeito construídas por aterro hidráulico [Livro] / A. Espósito Terezinha de Jesus. - Brasília : UnB - Universidade de Brasília, 2000.

MORAES, Christiane Marinho de. Aterros Reforçados Sobre Solos Moles Análise Numérica e Analítica. 2002. 32f. Trabalho de Conclusão de Curso (PósGraduação em Engenharia Civil) - Universidade Federal do Rio de Janeiro - Rio de Janeiro, 2002.

NATIONAL COOPERATIVE HIGHWAY RESEARCH, 2004, Report 529: Guideline and Recomended Sandard for Geofoam Applications in Highway Embankments, (Guia e Normas Recomendadas para Aplicações de Isopor em Aterros de Rodovias), NCHRP, Washington

NEGUSSEY, D. (1997). Properties and Applications of Geofoam, (Propriedades e Aplicações do Isopor), Society of the Plastics Industry, Inc. (This reference was provided by Thermal Foams during the field visit.)

OLIVEIRA, Hélio Martins de. Aglomerantes. In: BAUER, L. A. Falcão. (Coord.). Materiais de Construção. Rio de Janeiro: LTC, 2011. 1v. p. 11 - 34.

Pavimentação - Base de solo-cimento - Especificação de serviço / A. DNIT 143 ES. - Rio de Janeiro : DNIT, 2010. 
Pavimentação - Sub-base de solo melhorado com cimento - Especificação de serviço / A. DNIT 140 - ES. - Rio de Janeiro : DNIT, 2010.

Pavimentação Asfáltica: Formação Básica para Engenheiros [Livro] / A. BERNUCCI Liedi Bariani [et al.]. - Rio de Janeiro : PET ROBRAS: ABEDA, 2010. - Vol. 1.

PER TOMANI, N. B.; SVÄRD, S. H.; ÅMAND, L. Pilot-Scale Combustion with lignin as a solid bioful. Tappi Engineering, Pulping and Environmental Conference, Portland, 2008. p. 25-27.

PINTO, Carlos de Sousa. Curso Básico de Mecânica dos Solos em 16 aulas. $3^{a}$ Ed. São Paulo: Oficina de Textos, 2006.

Planejamento de manutenção [Livro] / A. Antonioli P. E.. - São Paulo : Pini, 2011.

PREBER, T., BANG, S., CHUNG, Y. and CHO, Y. (1994). Behavior of Expanded Polystyrene Blocks. (Comportamento de Blocos de Poliestireno Expandido), Transportation Research Record 1462, pp. 36-46

Rezende, D. A. (2013). Análise probabilística de estabilidade de taludes em barragem de rejeitos. Rio de Janeiro: UFRJ/ Escola Politécnica.

RIZZO, R. P.; LOLLO, J. A. Capacidade de retenção de barreiras de proteção produzidas com solo arenoso estabilizado quimicamente. Revista Engenharia Sanitária e Ambiental, Rio de Janeiro, v.11, n.3, p. 250-259, jul./set. 2006.

Secretaria de energia e mineração do estado de São Paulo [Online] / A. Avila Joaquim Pimenta de // Secretaria de energia e mineração. - 03 de 05 de 2016. http://www.energia.sp.gov.br.

Seleção de locais para barragens de rejeitos usando o método de análise hierárquica [Livro] / A. Lozano Fernando Arturo Erazo. - São Paulo : USP, 2006.

SNV - SISTEMA NACIONAL DE VIAÇÃO. SNV 2014 - Atualizado até 16/09/2014: 1-SNV 2014 COMPLETO - Rede rodoviária sob jurisdição do Ministério dos Transportes. Disponível em: <http://www.dnit.gov.br/sistema-nacional-deviacao/snv-2014-1> Acesso em: 21 nov. 2014. 
SOUSA, Alex Torres de. Estudo de parâmetros de dois tipos de solos característicos do Distrito Federal. 2013. 70 f. Trabalho de Conclusão de Curso (Graduação em Engenharia Civil) - Centro Universitário de Brasília - UniCEUB, Brasília, 2013.

SOUZA, Maurício José de. Patologia em Pavimentos Flexíveis. 2004. $63 \mathrm{f}$. Trabalho de Conclusão de Curso (Graduação em Engenharia Civil) - Universidade Anhembi Morumbi, São Paulo, 2004.

Standard Test Method for Direct Shear Test of Soils Under Consolidated Drained Conditions [Livro] / A. ASTM. - West Conshohocken : AMERICAN SOCIETY FOR TESTING AND MATERIALS - ASTM, 2004.

Transportes. Disponível em: <http://www.dnit.gov.br/sistema-nacional-deviacao/snv-2014-1> Acesso em: 21 nov. 2016. 